\title{
Adriane Calaboni
}

\section{Transição Florestal no estado de São Paulo, Brasil: fatores associados ao desmatamento e recuperação das matas nativas}

\author{
The Forest Transition in São Paulo, Brazil: drivers \\ related to forest loss and recovery
}

São Paulo 


\title{
Adriane Calaboni
}

\section{Transição Florestal no estado de São Paulo, Brasil: fatores associados ao desmatamento e recuperação das matas nativas}

\author{
The Forest Transition in São Paulo, Brazil: drivers \\ related to forest loss and recovery
}

Tese apresentada ao Instituto de Biociências da Universidade de São Paulo, para a obtenção de Título de Doutora em Ecologia: Área de Concentração: Ecologia de Ecossistemas Terrestres e Aquáticos.

Orientadora: Profa. Dra. María Uriarte Co-orientador: Prof. Dr. Leandro R. Tambosi

São Paulo 


\section{Ficha Catalográfica}

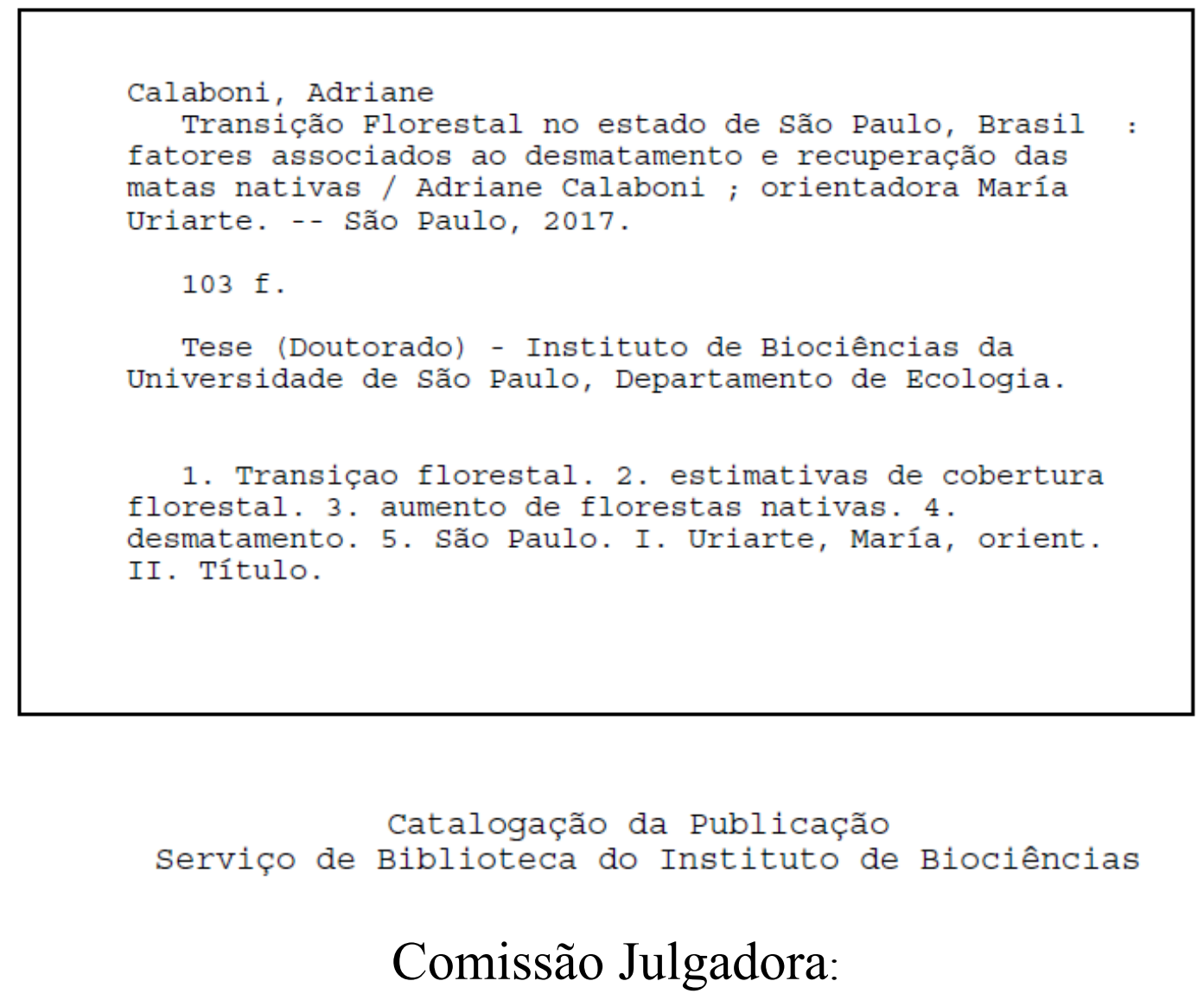

Prof(a). Dr(a).

Prof(a). Dr(a).

Prof(a). Dr(a).

Prof(a). Dr(a).

Profa. Dra. María Uriarte

Orientadora 


\section{Epígrafe}

Descobri como é bom chegar quando se tem paciência. E para se chegar, onde quer que seja, aprendi que não é preciso dominar a força, mas a razão. É preciso, antes de mais nada, querer.

Amyr Klink 


\section{Agradecimentos}

$\overline{\text { Agradeço a toda minha família, pais, irmãos, avós, tios e primos, pelo apoio amoroso }}$ nesta longa jornada acadêmica. Dedico esta conquista a vocês!

À minha querida tia Ana Elizia, por sempre me receber tão carinhosamente, pelas nossas conversas maravilhosas que muito me encorajaram e confortaram. À minha querida prima Ana Carla, pela amizade, pelas mensagens de carinho, companhia e risadas em minhas longas estadias em São Paulo. Aos queridos primos Danilo, Aline, Isabela, Leonardo, Caroline, Andressa e Samanta pela companhia, carinho e momentos adoráveis.

Ao Prof. Dr. Jean-Paul Metzger pela oportunidade de desenvolver este projeto, pela confiança e oportunidade de fazer parte do querido LEPAC.

Ao meu co-orientador, Prof. Dr. Leandro R. Tambosi, pela orientação exemplar, principalmente durante as mudanças de projeto e de orientador. Obrigada por todos os ensinamentos, pela paciência e amizade durante esta transição difícil.

Ao Prof. Alexandre T. Igari e à Dra. Juliana Farinaci pelos ensinamentos, pela amizade, pelo carinho e por participarem tão ativamente do desenvolvimento do projeto.

À minha orientadora, Profa. Dra. María Uriarte, por acreditar em mim e tão pacientemente guiar-me por um doutorado de dois anos, mas que apresento agora com muito orgulho. Muita obrigada!!

Agradeço aos meus queridos companheiros do LEPAC por me acolherem. Obrigada pela companhia, pelos ensinamentos, por todo o apoio e incentivo. Vocês foram essenciais para a superação de cada obstáculo. Muito obrigada!

Agradeço a Nerida Valero, Myldred Spinelli, Letícia Zimback, Gabriel Murayama, Catalina Rodriguez, Camila Barreto, Patrícia Koster e Silva, e Pamela Santana pelo companheirismo, pela força e muitas risadas!

A Welington Bispo, Vera Lima, Shirlene Barros e Luís Carlos de Souza pelo profissionalismo, dedicação e apoio em todas as fases de desenvolvimento desta tese. Aos meus amigos queridos Camila Hohlenwerger, Bruno Travassos, Liedson Carneiro, Willian Sabino e Felipe Librán pelas aventuras, pelos almoços, pelas risadas e por fazerem parte desta caminhada! 
Aos queridos Gustavo Burin (Ari), Paula Giroldo (Pooh), Prof. Milton Ribeiro e Prof. Jean Paul Metzger pelo apoio quando precisei escolher entre desistir ou encarar uma jornada arriscada. Muito obrigada! 


\section{Índice}

\begin{tabular}{ll}
\hline Resumo & 01
\end{tabular}

$\begin{array}{ll}\text { Abstract } & 02\end{array}$

$\begin{array}{ll}\text { Introdução Geral } & 03\end{array}$

$\begin{array}{ll}\text { Referências Bibliográficas } & \mathbf{1 0}\end{array}$

Capítulo 1. Native forest cover estimates by different methods:

$\begin{array}{ll}\text { exploring the sources of discrepancies } & \mathbf{1 5}\end{array}$

$\begin{array}{lc}\text { Introduction } & 18\end{array}$

$\begin{array}{lr}\text { Methods } & \mathbf{2 0}\end{array}$

$\begin{array}{ll}\text { Results } & 25\end{array}$

$\begin{array}{ll}\text { Discussion } & 27\end{array}$

$\begin{array}{ll}\text { Conclusion } & 31\end{array}$

$\begin{array}{ll}\text { Literature cited } & 32\end{array}$

Supplementary Information $\quad 48$

Capítulo 2. The forest transition in São Paulo, Brazil: historical patterns and putative drivers $\quad \mathbf{5 2}$

$\begin{array}{ll}\text { Introduction } & 55\end{array}$

$\begin{array}{ll}\text { Methods } & \mathbf{5 7}\end{array}$

$\begin{array}{lc}\text { Results } & \mathbf{6 0}\end{array}$

$\begin{array}{ll}\text { Discussion } & 63\end{array}$

$\begin{array}{lr}\text { Conclusion } & 67\end{array}$

$\begin{array}{lr}\text { Literature cited } & 68\end{array}$

$\begin{array}{ll}\text { Supplementary Information } & 81\end{array}$

$\begin{array}{ll}\text { Conclusão Geral } & 91\end{array}$ 



\section{Resumo}

Segundo a Teoria da Transição Florestal, países menos desenvolvidos teriam altas taxas de desmatamento, pois a economia destes países é baseada no desenvolvimento e expansão agrícola. Com o avanço do desenvolvimento econômico a industrialização, urbanização e a modernização do uso da terra levariam ao abandono de terras menos adequadas à agricultura que seriam ativamente reflorestadas ou regenerariam. Visto que São Paulo vem apresentando ganhos de cobertura florestal nativa, este estudo teve como objetivo principal identificar os fatores relacionados ao processo de transição florestal no estado de São Paulo entre 1960 e 2006. Para isso, o Capítulo 1 avaliou as discrepâncias entre três estimativas de cobertura florestal nativa disponíveis para o estado de São Paulo (censo agropecuário e dois mapeamentos com resolução de $10 \mathrm{~m}$ e $30 \mathrm{~m}$ ), em escala municipal, e as possíveis fontes de viés associadas aos métodos de coleta. O Capítulo 2 identificou os fatores socioeconômicos e biofísicos associados ao desmatamento e à recuperação das florestas nativas nos municípios do estado de São Paulo em quatro períodos consecutivos (1960-1970, 1970-1980, 1980-1996, 19962006). Os resultados do Capítulo 1mostraram que o censo agropecuário subestima a cobertura florestal quando há áreas protegidas nos municípios. Mapas com resolução de 30m também subestimam a cobertura florestal nativa em relação aos mapas com $10 \mathrm{~m}$ de resolução, visto que não detectam pequenos fragmentos. As três fontes de dados são congruentes, porém os vieses relacionados aos métodos podem refletir nos resultados. Logo, a escolha dos dados deve ser feita de acordo com os objetivos do estudo a ser desenvolvido e considerando os métodos de coleta e possíveis fontes de viés de cada conjunto de dados. O Capítulo 2 mostrou que as perdas de florestas ocorreram principalmente em municípios com solos mais úmidos e/ou naqueles em que houve expansão de cultivos. Enquanto ganhos de florestas ocorreram principalmente em municípios com maior cobertura florestal, maior declividade média, que empregaram maior número de trabalhadores permanentes e usaram mais fertilizantes. Estes resultados mostram que, entre 1960 e 2006, a expansão do uso da terra levou a perdas de florestas em áreas mais adequadas à agricultura de São Paulo. Com o tempo, porém, fatores que aumentam a produtividade ou reduzem a conversão de áreas naturais levaram ao aumento de florestas, principalmente em terras menos adequadas à agricultura. Tais fatores, no entanto, foram influenciados por políticas governamentais para modernização da agricultura e proteção dos ecossistemas naturais, e pela pressão do mercado externo por certificação ambiental. Estes resultados enfatizam a necessidade de se considerar, em conjunto, desenvolvimento da agricultura e conservação do meio ambiente para o desenvolvimento de políticas de uso da terra mais eficientes.

Palavras-chave: transição florestal; estimativas de cobertura florestal; desmatamento; recuperação de florestas nativas; São Paulo 


\section{Abstract}

According to Forest Transition Theory, less developed countries or regions present high rates of deforestation because their economy is based on agricultural development and agriculture expansion. As the economy develops industrialization, urbanization and agriculture modernization lead to the abandonment of lands less suitable for agriculture which are reforested or regenerate spontaneously. Since forest cover of São Paulo has increased, this study aimed to identify the socioeconomic and biophysical factors related to forest transition in the state of São Paulo between 1960 and 2006. For this purpose, Chapter 1 evaluate the discrepancies among three free datasets of São Paulo's forest cover (agricultural census, maps at $10 \mathrm{~m}$ and $30 \mathrm{~m}$ resolution), in municipality-scale, and the possible sources of bias. Chapter 2 identified the factors related to deforestation and forest gains in São Paulo's municipalities during four consecutive intervals (1960-1970, 1970-1980, 1980-1996, 1996-2006). Chapter 1 showed that census underestimate forest cover when legally protected areas are present, reflecting the limitation of survey methods in rural properties. Maps at $30 \mathrm{~m}$ resolution also underestimate forest cover in comparison to maps at $10 \mathrm{~m}$ resolution, since $30 \mathrm{~m}$ resolution cannot detect small and narrow patches. The three datasets are congruent, but the results indicate that bias related to methods can affect analysis results. Therefore, users should choose a dataset according to aims of the study and considering the sources of bias in the data. Chapter 2 showed that forest losses were greater in municipalities with moist soils and large tracts of agricultural lands, while forest gains were higher in municipalities with high forest cover and steep slopes, and that employed a large number of permanent workers and relied on high fertilizer input. Between 1960 and 2006, land use expansion led to forest losses in more suitable areas for agriculture in São Paulo. Over time, factors that increase productivity or reduce pressure on land development led to forest gains mainly in less suitable lands. These proximate factors, however, were driven by underlying factors as governmental policies to modernize agriculture and protect natural ecosystems, and by external market demands for environmental certification. These results highlight the need to jointly consider agricultural development and environmental conservation policies for the development of effective land use policies.

Key-words: forest transition; forest cover estimates; deforestation; forest recovery; São Paulo 


\section{Introdução Geral}

Há décadas países tropicais em desenvolvimento apresentam altas taxas de desmatamento, em grande parte devido à expansão das áreas agrícolas sobre florestas primárias (Gibbs et al. 2010, Hansen et al. 2013, Kim et al. 2015). Em alguns países, como Brasil, estas taxas declinaram significativamente (Hansen et al. 2013), em outros, como Panamá, Guatemala e Costa Rica, ganhos líquidos de cobertura florestal nativa estão ocorrendo (Aide et al. 2013, Crk et al. 2009, Yackulic et al. 2011, Redo et al. 2012). Este processo de reversão de tendências é descrito pela Teoria da Transição Florestal (Mather 1992).

A Teoria da Transição Florestal (TTF) é baseada na Curva de Kuznets Ambiental (CKA) que relaciona o crescimento econômico, geralmente medido pela renda per capta, à degradação ambiental. De acordo com a CKA, o crescimento da economia inicialmente promove a degradação ambiental. À medida que a economia cresce e a degradação atinge seu máximo, a qualidade ambiental melhora em resposta à preocupação com o meio ambiente e aos esforços para proteção ambiental (Dinda 2005). O resultado é uma curva em forma de "U” invertido (Fig. 1A).

A

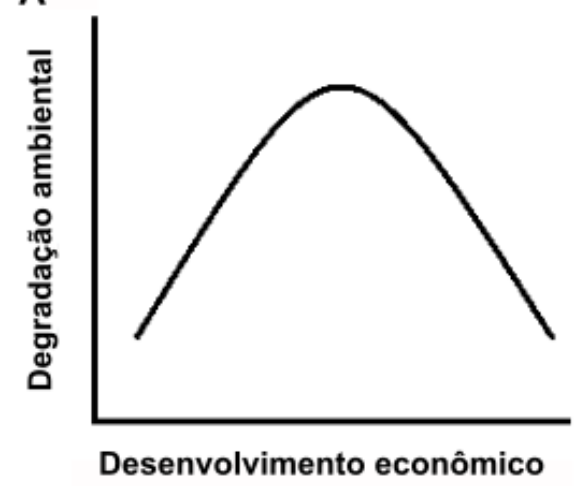

B

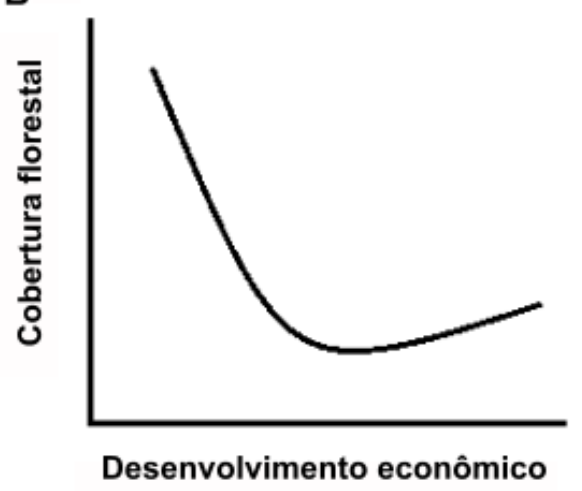

FIGURA 1. Curva de Kuznets Ambiental (A) e Curva da Transição Florestal (B).

Similarmente, a TTF descreve a relação entre a cobertura florestal e o desenvolvimento econômico de uma nação (Fig. 1B). A transição ocorre quando o desmatamento e a conversão de áreas naturais para outras formas de cobertura das terras são superados pelo aumento de áreas florestais. Assim que o desenvolvimento 
econômico atinge determinado limiar no qual a cobertura florestal é mínima, os países começam a apresentar ganhos líquidos de cobertura florestal (Fig. 1B) (Mather 1992). Este processo é dividido em quatro fases (Fig. 2) (Angelsen 2007).

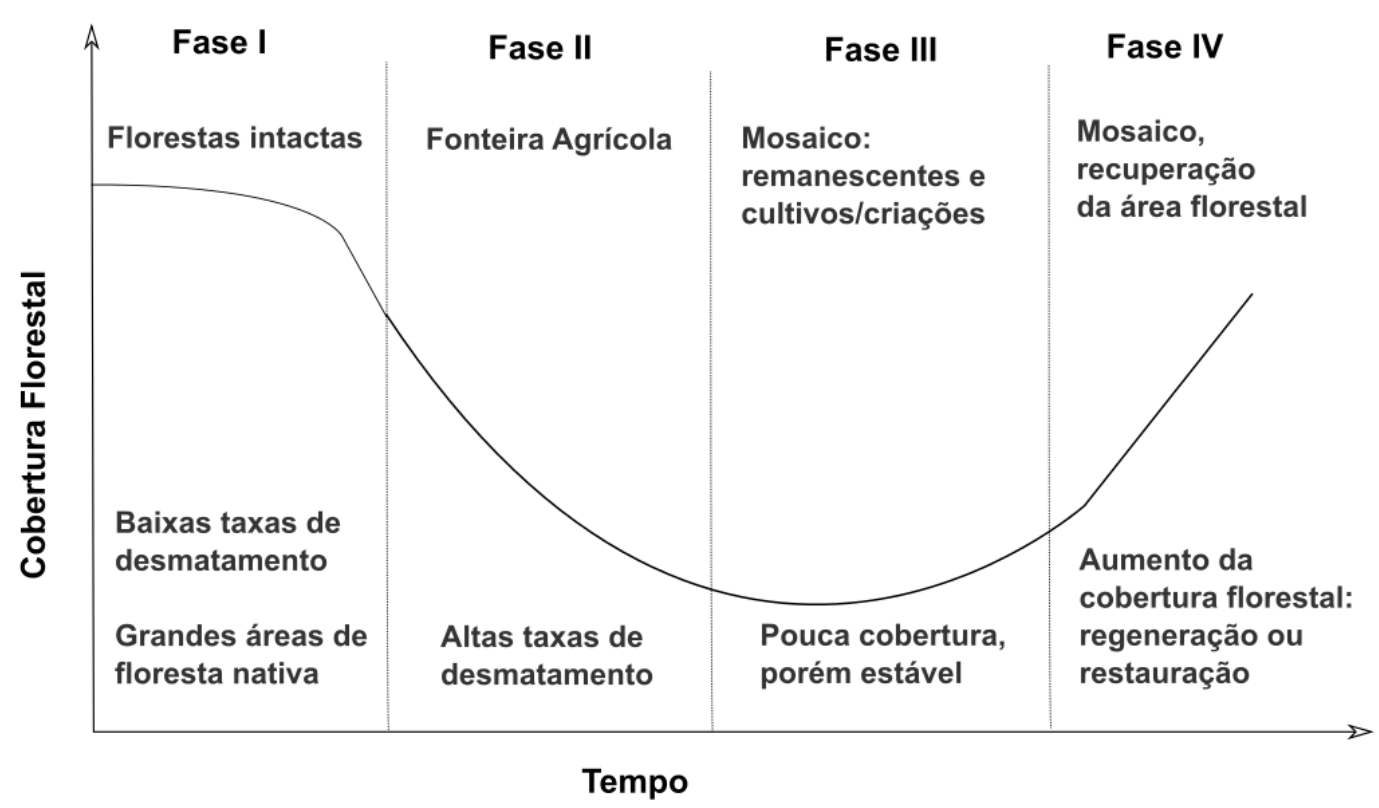

FIGURA 2. Fases do processo de transição florestal (Fase I a IV) e a variação da cobertura florestal em cada fase. Modificado de Angelsen (2007).

Num primeiro estágio do desenvolvimento econômico, o país ou região possui grandes extensões de florestas intactas e taxas muito baixas de desmatamento (Fig. 2, Fase I). Posteriormente, a expansão da agricultura, principal meio de subsistência e de crescimento econômico em países em desenvolvimento, provoca a conversão de extensas áreas de florestas nativas em pastos e cultivos agrícolas (Fig. 2, Fase II). Quando as florestas nativas são reduzidas a pequenos remanescentes imersos em matriz agrícola, o desmatamento desacelera e estabiliza (Fig. 2, Fase III). Mudanças sociais, políticas e econômicas favorecem a recuperação das florestas, por meio do abandono de terras e regeneração espontânea das florestas ou promovendo a restauração de áreas degradadas (Fig. 2, Fase IV) (Angelsen 2007).

O desmatamento é causado por diversos fatores que influenciam diretamente (e.g. expansão da agricultura, construção de estradas, extração de madeira, entre outros) ou indiretamente (e.g. modernização da agricultura, industrialização, urbanização, desenvolvimento de políticas públicas, entre outros) as decisões em 
relação aos tipos de uso da terra (Geist \& Lambin 2002). A conversão seguida de recuperação das florestas resulta de interações complexas entre estes fatores (Mather 1992, Mather \& Needle 1999, Rudel et al. 2005, Barbier et al. 2010, Lambin \& Meyfroidt 2010, Molin et al. 2017).

Alguns autores buscaram identificar os mecanismos (e fatores) associados à transição florestal, e descreveram vias ou caminhos para sua ocorrência. Entre as vias descritas estão a via da escassez florestal (Forest scarcity pathway), a via das políticas públicas (State forest pathway), a via do desenvolvimento econômico (Economic development pathway), a via da globalização (Globalization pathway) e a via do pequeno produtor (Smallholder, tree-based land use pathway) (Rudel et al. 2005, Lambin \& Meyfroidt 2010).

A via da escassez florestal (Forest scarcity pathway) sugere que os ganhos líquidos de cobertura florestal nativa são uma resposta ao declínio de produtos florestais e da provisão de serviços ecossistêmicos, que encorajam programas governamentais de recuperação das florestas (Rudel et al. 2005). Segundo a via das políticas públicas (State forest pathway), a escassez de produtos florestais também poderia incentivar o desenvolvimento de políticas públicas para a modernização da economia e uso da terra, integração de minorias étnicas, incentivo ao turismo ecológico e à criação de uma imagem mais "verde" do país que levariam à conservação e ao aumento das florestas (Lambin \& Meyfroidt 2010).

O desenvolvimento da economia é apontado pela via do desenvolvimento econômico (Economic development pathway) como gatilho para o aumento das florestas nativas, pois encorajaria a migração da força de trabalho rural para os setores da indústria e serviços nos centros urbanos. O declínio da mão-de-obra e consequente aumento de custos na agricultura com mão-de-obra levariam à intensificação da agricultura em terras mais férteis e abandono de terras marginais (Rudel et al. 2005). Impulsionada pelo desenvolvimento econômico, a integração da economia ao mercado internacional por meio de commodities, turismo ecológico, ideias conservacionistas e acordos ambientais multilaterais também teriam efeitos positivos sobre as florestas nativas, de acordo com a via da globalização (Globalization pathway) (Lambin \& Meyfroidt 2010).

Por fim, a via do pequeno produtor (Smallholder, tree-based land use pathway) destaca o importante efeito das decisões dos pequenos proprietários sobre a 
manutenção das florestas. Visto que são diretamente afetados pelo declínio da provisão de serviços ecossistêmicos em suas propriedades, os pequenos agricultores utilizariam inovações nos sistemas rurais para um cultivo mais amigável, como sistemas agroflorestais, além de espontaneamente utilizarem cercas-vivas e manterem alguma cobertura florestal nativa nas propriedades (Lambin \& Meyfroidt 2010).

Além dos fatores descritos nas vias propostas, o ajuste agrícola a áreas mais produtivas também tem sido associado a ganhos de cobertura florestal. A concentração da produção em áreas mais férteis aliada ao uso de tecnologias levaria ao aumento significativo da produtividade. Como consequência, a expansão agrícola declinaria e terras pouco produtivas seriam abandonadas e recuperariam a vegetação nativa (Mather \& Needle 1998, Igari \& Tambosi 2016).

Embora coerentes com os mecanismos que possivelmente conduzam a transição florestal, os fatores associados ao aumento da cobertura florestal nativa de cada país ou região são específicos, pois refletem mudanças socioeconômicas, políticas e culturais em cada localidade e em períodos específicos (Perz \& Walker 2002, Mather \& Needle 1999, Uriarte et al. 2010, Zhang et al. 2015). Logo, dependendo do contexto, os mesmos fatores apontados pelas vias da transição florestal podem interagir diferentemente, levando ao desmatamento ao invés de recuperação das áreas nativas. Por exemplo, o decréscimo da população rural não leva necessariamente à recuperação das florestas nativas (Mather \& Needle 1999), mas pode promover a fragmentação de florestas em resposta ao crescimento da população urbana e expansão dos grandes centros urbanos (Crk et al. 2009, Yackulic et al. 2011, Gao \& Yu 2014).

O aumento de florestas secundárias, por sua vez, pode ocorrer paralelamente à perda de florestas primárias, reduzindo a idade dos remanescentes florestais nativos. Esta secundarização dos remanescentes leva ao empobrecimento da biodiversidade e ao declínio da provisão de serviços ecossistêmicos (Lira et al. 2012, Ferraz et al. 2014). Além disso, tais ganhos de florestas secundárias podem estar associados ao deslocamento da produção agrícola para áreas com menores custos de produção ou leis ambientais e trabalhistas menos rígidas, onde o desmatamento ocorre em larga escala (Pfaff \& Walker 2010, Meyfroidt et al. 2010, Walker 2012). Isto explica por que os estados brasileiros de Santa Catarina (Baptista \& Rudel 2006, Baptista 2008), Rio de Janeiro (Costa et al. 2017) e São Paulo (Lira et al. 2012, Farinaci \& Batistella 
2012, Barretto et al. 2013, Silva et al. 2016, Molin et al. 2017) apresentaram ganhos líquidos de cobertura florestal nativa, enquanto o desmatamento ainda predomina em outras regiões como Centro-Oeste e Norte do Brasil (Walker 2012, Barretto et al. 2013).

De acordo com relatórios técnicos realizados periodicamente pela organização não governamental SOS Mata Atlântica em parceria com Instituto Nacional de Pesquisas Espaciais (INPE), o estado de São Paulo vem mostrando considerável desaceleração do desmatamento desde a década de 1990 (SOS/INPE, 2016) e ganhos líquidos de cobertura florestal nativa (Teixeira et al. 2009, Lira et al. 2012, Farinaci \& Batistella 2012, Ferraz et al. 2014, Silva et al. 2016, Molin et al. 2017). Somado a isso, São Paulo destaca-se dos outros estados brasileiros devido ao alto nível de urbanização, alta contribuição ao PIB nacional, economia centrada nos setores de serviços e indústria, agricultura fortemente associada ao agronegócio e a investimentos em tecnologia e inovação. Neste contexto, é plausível que São Paulo esteja passando pela transição florestal, como destacado por estudos realizados em diferentes regiões do estado (Lira et al. 2012, Silva et al. 2016, Molin et al. 2017).

No decorrer do século XX, São Paulo esgotou suas fronteiras agrícolas e montou uma potente agroindústria voltada para a exportação, como por exemplo, a indústria do suco concentrado de frutas cítricas (Maia 1996). A criação do Sistema de Crédito Rural em 1965 impulsionou a transição do uso da terra no estado ao encorajar a modernização da agricultura no Brasil (Igari \& Pivello 2011), que resultou em importantes mudanças socioeconômicas em São Paulo como a mecanização da agricultura, intenso êxodo rural e urbanização, aumento significativo no uso de fertilizantes e pesticidas, e expansão da área cultivada para a produção de commodities (Veiga \& Otani 1983, Camargo \& Santos 1985, Vicente 1985, Garcia 1986, Carvalho \& Silva 1987, Chabaribery 1999). Paralelamente, o governo brasileiro criou o Código Florestal Brasileiro (Lei ${ }^{\circ} 4.771$ de 1965), lei que estabeleceu áreas a serem preservadas dentro de propriedades rurais (e.g. Áreas de Proteção Permanente e Reserva Legal) e regras para uso sustentável de áreas nativas brasileiras; o Conselho Nacional do Meio Ambiente - CONAMA (Lei nº 6.938 de 1981), órgão que cria normas e assessora o governo federal para o desenvolvimento de políticas de exploração e preservação dos ecossistemas naturais; e o Instituto Brasileiro do Meio Ambiente e dos Recursos Renováveis - IBAMA (Lei nº 7.735 de 1989), órgão que 
objetiva a preservação do meio ambiente e uso sustentável dos recursos naturais, mas tem autonomia para fiscalização ambiental, monitoramento ambiental e aplicação de penalidades administrativas. Enquanto que, o governo paulista criou o Conselho Estadual do Meio Ambiente - CONSEMA (Decreto nº 20.903 de 1983), órgão estadual que estabelece normas, acompanha a política ambiental no estado e conduz audiências públicas para decisão e proposição de medidas de preservação e recuperação do meio ambiente.

A via da globalização parece explicar a recuperação das florestas de São Paulo, visto que a modernização da agricultura e a expansão da área cultivada com commodities foram importantes para a economia do estado durante o século XX (Chabaribery 1999). Em contrapartida, a criação de vários órgãos ambientais pelos governos brasileiro e paulista indica crescente preocupação com o meio ambiente neste período (e.g. via das políticas públicas).

Estudos sobre a transição florestal no estado de São Paulo foram feitos em escala regional no Vale do Paraíba para o período de 1985 a 2011 (Silva et al. 2016) e sub-regional na Bacia do Rio Piracicaba para o período de 1990 a 2010 (Molin et al. 2017). A regeneração nestas regiões ocorreu principalmente em áreas próximas de remanescentes de Mata Atlântica, menos adequadas à agricultura e distantes de centros urbanos e estradas (Silva et al. 2016, Molin et al. 2017). Este aumento de florestas deveu-se principalmente ao abandono de terras para compensação das áreas de Reserva Legal e Áreas de Proteção Permanente para o cumprimento da legislação pelos proprietários, e para a obtenção de certificação ambiental pela agroindústria da cana-de-açúcar na Bacia do Rio Piracicaba (Molin et al. 2017) e de papel e celulose no Vale do Paraíba (Silva et al. 2016). No entanto, outros fatores como o êxodo rural em resposta à industrialização, o desenvolvimento do turismo ecológico e a distribuição desigual de crédito rural em benefício do agronegócio foram importantes para o abandono das terras em alguns municípios do Vale do Paraíba, indicando a ocorrência de mais de uma via de transição florestal na região ao longo do tempo (Silva et al. 2016).

Com base na constatação do processo de transição florestal em escala regional e sub-regional em São Paulo, este estudo buscou identificar os fatores socioeconômicos e biofísicos relacionados ao desmatamento e à recuperação das florestas nativas do estado de São Paulo. Este é o primeiro estudo da transição 
florestal em São Paulo que abrange todos os seus 645 municípios em longo prazo (1960-2006). Compreender os fatores associados a esses processos no estado de São Paulo é fundamental para elaboração de medidas e adoção de políticas públicas que busquem a conservação das áreas nativas (Hersperger et al. 2010). Além disso, entender como estes fatores variam ao longo do tempo permite explorar cenários futuros de mudanças no uso da terra e suas consequências para a cobertura florestal nativa e para a manutenção da biodiversidade do estado de São Paulo.

Este trabalho é constituído por dois capítulos apresentados na forma de artigo científico. O Capítulo 1 buscou identificar as possíveis fontes de discrepância entre os dados de cobertura florestal nativa de três fontes distintas que estão disponíveis para o estado de São Paulo em escala municipal. São eles, dados do Censo Agropecuário do IBGE (IBGE 2006), mapeamento elaborado pela ONG SOS Mata Atlântica com resolução espacial de 30m para o período de 2005 a 2008 (SOS/INPE 2009), e mapeamento elaborado pelo Instituto Florestal do Estado de são Paulo (SIFESP 2010) com resolução de $10 \mathrm{~m}$ para o ano de 2010. Cada uma das fontes de dados de cobertura florestal possuem erros e incertezas associadas aos métodos de obtenção. Assim, uma análise sobre a consistência das estimativas provenientes de diferentes fontes de dados de cobertura florestal do estado é crucial para que futuros estudos voltados para o entendimento dos processos de desmatamento e recuperação da cobertura florestal nativa possam avaliar, por exemplo, a possibilidade de combinar estimativas de diferentes fontes para criar séries temporais mais longas.

Os objetivos específicos do Capítulo 1 foram verificar:

(1) Se as estimativas de cobertura florestal obtidas por censo (IBGE) e por imagens de satélite (IF e SOS) são equivalentes.

(2) Se as diferenças: (a) entre as estimativas de censo e mapeamentos podem ser explicadas por características dos municípios como área do município, área censeada, e a extensão de áreas protegidas nos municípios (Unidades de Conservação e Áreas de Proteção Permanente); (b) entre as estimativas de mapeamentos refletem variações na configuração da paisagem, ou seja, na forma dos fragmentos, distância média do vizinho mais próximo, área total dos fragmentos.

(3) Se (a) a porcentagem de cobertura florestal nos municípios está relacionada à quantidade de Unidades de Conservação, extensão das Áreas de Proteção Permanente (e.g. margens de rios e cursos d'água, topo de morros e áreas com declive 
superior a $45^{\circ}$ ) e características do solo (e.g. capacidade de retenção de água) nos municípios; e se (b) esta relação se mantêm com o uso diferentes fontes de dados de cobertura florestal nas análises.

(4) Se o uso de diferentes fontes de dados para complementar uma série temporal resulta em diferentes estimativas de tendências de cobertura florestal.

Utilizando os dados do Censo Agropecuário - IBGE, o Capítulo 2 buscou identificar os fatores relacionados às variações da cobertura florestal nativa no estado de São Paulo em quatro períodos distintos entre 1960 e 2006. Os objetivos específicos do Capítulo 2 foram identificar:

(1) Os padrões de perdas e ganhos de cobertura florestal em escala estadual durante quatro períodos consecutivos (1960-1970, 1970-1980, 1980-1996 e 19962006);

(2) Os fatores socioeconômicos e biofísicos relacionados às perdas e ganhos de cobertura florestal nos municípios de São Paulo em quatro períodos consecutivos (1960-1970, 1970-1980, 1980-1996 e 1996-2006).

\section{REFERÊNCIAS BIBLIOGRÁFICAS}

Aide, T.M., M.L. Clark, H.R. GraU, D. LÓPES-CARr, M.A. LEVy, D. Redo, M. Bonilla-Moheno, G. Riner, M.J. ANDRAdE-NúÑEZ, and M. MuÑIZ. 2013. Deforestation and Reforestation of Latin America and the Caribbean (20012010). Biotropica 45: 262-271.

ANGELSEN, A. 2007. Forest cover change in time and space: combining the Von Thunen and Forest Transition Theories. The World Bank Policy Research Working Paper 4117.

BAPTISTA, S.R. Metropolitanization and forest recovery in Southern Brazil: a multiscale analysis of Florianópolis City-Region, Santa Catarina State, 1970 to 2005. 2008. Ecol. Soc. 13:5.

BAPTISTA, S.R., and T.K. RUDEL. 2006. A re-emerging Atlantic forest? Urbanization, industrialization and the forest transition in Santa Catarina, southern Brazil. Environ. Conserv. 33: 195 - 202.

BARBIER, E.B., J.C. BuRgESS, and A. GRAINGER. 2010. The forest transition: towards a more comprehensive theoretical framework. Land Use Policy 27: 98-107. 
Barretto, A. G. O. P., G. Berndes, G. SparoveK, and S. Wirsenius. 2013.

Agricultural intensification in Brazil and its effects on land-use patterns: An analysis of the 1975-2006 period. Glob. Chang. Biol. 19: 1804-1815.

CAmargo, A. M. M., and Z. A. P. SAntos. 1985. Mudança na composição agrícola paulista: o caso da soja, da laranja e da cana-de-açúcar. IEA: São Paulo. Available at: http://www.iea.sp.gov.br/out/TerTexto.php?codTexto=10619.

Carvalho, M. A., and C. R. L. Silva. 1987. Uma análise dos fatores que influenciaram a produção agrícola no Estado de São Paulo: alimentos x produtos exportáveis. IEA: São Paulo. Available at: http://www.iea.sp.gov.br/out/TerTexto.php?codTexto=10661.

CHABARIBERY, D. 1999. Inovação e desigualdade no desinvolvimento da agricultura paulista. Coleção Estud. Agrícolas 7: 1-178. Available at: http://www.iea.sp.gov.br/out/verTexto.php?codTexto=9623.

Costa, R.L., J.A. Prevedello, B.G. DE Souza, and D.C. CABral. 2017. Forest transition in tropical landscapes: a test in the Atlantic Forest biodiversity hotspots. Appl. Geogr. 82:93-100.

CRK, T., M. URIARTE, F. CORSI, and D. FLYNN. 2009. Forest recovery in a tropical landscape: what is the relative importance of biophysical, socioeconomic, and landscape variable? Landsc. Ecol. 24:629-652.

DindA, S. 2005. A theoretical basis for the environmental Kuznets curve. Ecol. Econ. 53:403-413.

FARINACI, J. S., and M. BATISTELLA. 2012. Variação na cobertura vegetal nativa em São Paulo: um panorama do conhecimento atual. Rev. Árvore 36: 695-705.

Ferraz, S. F. B., K. M. P. M. B. Ferraz, C. C. Cassiano, P. H. S. Brancalion, D. T. A. Da Luz, T. N. Azevedo, L. R. Tambosi, and J. P. MetzGer. 2014. How good are tropical forest patches for ecosystem services provisioning? Landsc. Ecol. 29: 187:200.

GARCIA, A. E. B. 1986. Ocupação da mão-de-obra na agricultura do Estado de São Paulo na década de 70. IEA: São Paulo. Available at: ftp://ftp.sp.gov.br/ftpiea/rea/tomo1_2_85.

GAO, Q., and M. YU. 2014. Discerning fragmentation dynamics of tropical forest and wetland during reforestation, urban sprawl, and policy shifts. PLOS ONE 9: e11140. 
GEIST, H. J., and E. F. LAMBIN. 2002. Proximate causes and underlying driving forces of tropical deforestation. Bioscience 52: 143-150.

GibBs, H. K., A. S. Ruesc, F. Achard, M. K. Clayton, P. Holmgren, N. RAMANKUTTY, and J. A. FOLEY. 2010. Tropical forests were the primary sources of new agricultural land in 1980s and 1990s. PNAS. 107(38): 1673216737.

Hansen, M.C., P.V. Potapov, R. Moore, M. Hancher, S.A. Turubanova, D. Thau, S.V. Stehman, S.J. Goets, T.R. Loveland, A. Kommareddy, A. Egorov, L. Chini, C.O. Justice, and J.R.G. Townshend. 2013. Highresolution global maps of $21^{\text {st }}$-Century forest cover change. Science 342: 850853.

Hersperger, A.M., M. GenNAio, P.H. Verburg, and M. BÜRgi. 2010. Linking land change with driving forces and actors: four conceptual models. Ecol. Soc. 15:1. Available at: https://www.ecologyandsociety.org/vol15/iss4/art1/

IBGE. 2006. Censo Agropecuário: Brasil, Grandes Regiões e Unidades da Federação. IBGE: Rio de Janeiro, 777p. Available at

http://www.ibge.gov.br/home/estatistica/economia/agropecuaria/censoagro/default.sht m Access in 04/20/2015.

IgARI, A.T., and V.R. Pivello. 2011. Crédito Rural e Código Florestal: irmãos como Caim e Abel? Ambiente e Sociedade 14: 133-150.

IgARI, A.T., and L. R. TAMBOSI. 2016. Agribusiness and socioeconomic drivers of land cover change in Brazil. In C. Gheler-Costa, M. C. Lyra-Jorge, L.M. Verdade (Ed.). Biodiversity in Agricultural landscapes of Southeastern Brazil, pp.28-42. De Gruyter, Berlin.

KIM, D., J.O. SEXTON, and J.R. TOWNSHEND. 2015. Accelerated deforestation in the humid tropics from the 1990's to the 2000's. Geophys. Res. Lett. 42: 34953501.

LAMBIN, E.F., and P. MEYFROIDT. 2010. Land use transitions: socio-ecological feedback versus socio-economic change. Land Use Policy 27:108-118.

LiRA, P. K., L. R. TAMBosi, R. M. Ewers, and J. P. MetzGER. 2012. Land-use and land-cover change in Atlantic Forest landscapes. For. Ecol. Manage. 278: 8089. 
MAIA, M. L. 1996. Citricultura Paulista: evolução, estrutura e acordo de preços. IEA: São Paulo. Available at: http://www.iea.sp.gov.br/out/verTexto.php?codTexto=10765 MATHER, A.S.1992. The forest transition. Area 24:367-379.

MAther, A.S., and C. L. NeEDLE. 1998. The forest transition: a theoretical basis. Area $30.2: 117-124$

MEYFROIDT, P., T.K. RUDEL, E.F. LAMBIN. 2010. Forest transition, trade, and global displacement of land use. PNAS 107:20917-20922.

Molin, P.G., S.E. Gergel, B.S. SoAres-Filho, and S.F.B. Ferraz. 2017. Spatial determinants of Atlantic Forest loss and recovery in São Paulo. Landsc. Ecol. 32: $857-870$.

PERZ, S.G., R.T. WALKER. 2002. Household life cycles and the secondary forest cover among small farm colonists in the Amazon. World Dev. 30:1009-1027.

PFAFF, A., and R. WALKER. 2010. Regional interdependence and forest "transitions": substitute deforestation limits the relevance of local reversals. Land Use Policy 27:119-129.

Redo, D. J., H. R. Grau, T. M. Aide, and M. L. Clark. 2012. Asymmetric forest transition driven by the interaction of socioeconomic development and environmental heterogeneity in Central America. Proc. Natl. Acad. Sci. U. S. A. 109: 8839-44.

Rudel, T.K., O.T. COOMES, E. MoRAN et al. 2005. Forest transition: towards a global understanding of land change. Glob. Environ. Change 15:23-31.

Silva, R. F. B., M. Batistella, and E. F. Moran. 2016. Drivers of land change: human-environment interactions and the Atlantic forest transition in the Paraíba Valley, Brazil. Land Use Policy 58: 133-144.

SIFESP - Sistema de INFORMAÇÕES FloRESTAIS do Estado DE SÃo PAUlo. 2010. Available at http://www.iflorestal.sp.gov.br/sifesp/ .

SOS Mata AtlâNTICA, Instituto Nacional de Pesquisas EsPaCiaIS (INPE). Atlas dos Remanescentes Florestais da Mata Atlântica: Período 2005-2008. 2009. SOS: São Paulo. Available at http://mapas.sosma.org.br/dados/\#.

SOS Mata Atlântica, Instituto Nacional De Pesquisas EsPaciais (INPE). Atlas dos Remanescentes Florestais da Mata Atlântica: Período 2014-2015. 2016. SOS: São Paulo. Available at: http://mapas.sosma.org.br/dados/\# . 
TeiXeira, A.M.G., B. SoARES-Filho, S.R. Freitas, and J.P. MEtZGer. 2009.

Modeling landscape dynamics in an Atlantic rainforest region: implications for conservation. Forest Ecol. Manag. 257:1219-1230.

URIARTE, M., L. SCHNEIDER, and T.K. RUDEL. 2010. Synthesis: land transition in the tropics. Biotropica 42:59-62.

VEIGA, J. E. R., and M. N. OTANI. 1983. Relações de trabalho na agricultura paulista: o declínio da mão-de-obra permanente. IEA: São Paulo. Available at: http://www.iea.sp.gov.br/out/LerTexto.php?codTexto=12011.

VICENTE, M. 1985. A evolução do uso da mão-de-obra e da mecanização em culturas do Estado de São Paulo. IEA: São Paulo. Available at: http://www.iea.sp.gov.br/out/verTexto.php?codTexto=10617

WALKER, R. 2012. The scale of forest transition: Amazonia and the Atlantic forests of Brazil. Appl. Geogr. 32:12-20.

YACKULIC, C.B., M. FAGAN, M. JAIN, et al. 2011. Biophysical and socioeconomic factors associated with forest transitions at multiple spatial and temporal scales. Ecol.Soc. 16:15.

ZHANG, L., Y. KonO, S. KoBAYASHI, et al. 2015. The expansion of smallholders rubber farming in Xishuangbanna, China: a case study of two villages. Land Use Policy 42:628-634. 


\section{Capítulo 1}

\section{DIFFERENCES IN NATIVE FOREST COVER ESTIMATES BETWEEN REMOTELY SENSED AND CENSUS DATA: EXPLORING PATTERNS AND SOURCES OF BIAS}

Adriane Calaboni, Leandro R. Tambosi, Juliana Farinaci, Alexandre T. Igari, Jean Paul Metzger, María Uriarte 
DIFFERENCES IN NATIVE FOREST COVER ESTIMATES BETWEEN

REMOTELY SENSED AND CENSUS DATA: EXPLORING PATTERNS AND SOURCES OF BIAS

Adriane Calaboni $^{1^{*}}$, Leandro R. Tambosi ${ }^{1,2}$, Juliana Farinaci ${ }^{3 \&}$, Alexandre T. Igari ${ }^{4 \&}$, Jean Paul Metzger ${ }^{1}$, María Uriarte ${ }^{5}$

${ }^{1}$ Departamento de Ecologia, Instituto de Biociências, Universidade de São Paulo, SP, Brasil

${ }^{2}$ Centro de Engenharia, Modelagem e Ciências Sociais Aplicadas, Universidade Federal do ABC, Santo André, SP, Brasil

${ }^{3}$ Centro de Ciência do Sistema Terrestre (CCST), Instituto Nacional de Pesquisas Espaciais (INPE), São José dos Campos, SP, Brasil

${ }^{4}$ Escola de Artes, Ciências e Humanidades, Universidade de São Paulo, SP, Brasil

${ }^{5}$ Department of Ecology, Evolution \& Environmental Biology, Columbia University,

New York City, NY, United States of America

*Corresponding author

E-mail: bioadriane@gmail.com

${ }^{\&}$ These authors contributed equally to this work 


\section{ABSTRACT}

Human needs for food, water, shelter, and fiber have driven dramatic deforestation worldwide. Recently, however, native forest recovery has been detected in several countries, including developing ones. Understanding the causal factors related to this pattern relies on robust estimates of forest cover change quantified at the appropriate spatial scale. Different forest cover estimates rely on different methods that may introduce particular biases. Choosing the appropriate dataset demands some knowledge about the magnitude and causes of these biases. This study evaluates discrepancies in municipality-scale forest cover estimates of São Paulo, Brazil among three datasets: forest census inventories and two remote sensing datasets collected at two spatial resolutions ( $10 \mathrm{~m}$ and $30 \mathrm{~m}$ pixels). To do so, we compared the three estimates and evaluated the municipality and landscape factors that underlie discrepancies between the three estimates. We also assessed if models depicting forest cover amount on the municipalities provide equivalent results when using the different datasets, and if combining different dataset for creating a time series provide a robust trend of forest cover change. Census methods underestimate forest cover when legally protected areas are present, reflecting the limitation of survey methods in rural areas. Estimates are more congruent in municipalities with large urban areas, possibly because the few and very small forest patches in urban areas are not easily detected using remotely sensed data. Forest cover is also underestimated by the coarser $30 \mathrm{~m}$ resolution maps in highly fragmented areas where forest patches are small, linear and complex. Small and linear patches are not quantified in coarser resolution maps, while isolated groups of patches are captured as one single large patch. Models depicting forest cover amount in the municipalities using different datasets provided similar results but different power of explanation, while combined time series provided contradictory trends for some municipalities. The three dataset we tested are all useful, but our study highlights that users should choose a dataset according to the aims of the study and considering the sources of biases in the data.

Key-words: forest cover, remote sensing data, census data, data discrepancies 


\section{INTRODUCTION}

Human needs for food, water, shelter, and fiber have driven dramatic deforestation worldwide. We now face the challenge of managing trade-offs between immediate human needs and biosphere's capacity to provide resources and services in the long term (Foley et al. 2005). However, native forest recovery has been detected in several countries, including Brazil (Crk et al. 2009, Yackulic et al. 2011, Redo et al. 2012, Farinaci \& Baptistella 2012, Aide et al. 2013, Silva et al. 2016, Molin et al. 2017, Costa et al. 2017). This trend of forest cover change is related to socioeconomic and political factors which can promote deforestation or forest recovery, according to prior socioeconomic, political and historical contexts (Geist \& Lambin 2002, Lambin \& Meyfroidt 2010). Understanding drivers and consequences of deforestation or forest recovery depend on robust estimates of forest cover collected at the appropriate spatial scale.

Since 1947, Food and Agriculture Organization of the United Nations (FAO) publishes the Global Forest Assessment, which use forest cover data provided by countries to estimate global forest cover change (Leloup 1947, Holmgren \& Persson 2002). The data are collected using different methods as census, field inventories and remote sensing, and many countries do not provide up-to-date data nor have complete data available (Holmgren \& Persson 2002). As a result, FAO's reports may not detect a decrease in global deforestation rate or increase in forest cover adequately (Stokstad 2001, Grainger 2008). For example, while FAO's report detected a significant decrease in global annual deforestation rate between 1990 and 2005 (FAO 2010), another report from FAO and European Commission Joint Research Centre (JRC) derived exclusively from remote sensing data detected an increase of deforestation rate for the same period (FAO \& JRC 2012).

Forest cover definitions are also reflected in the accuracy of forest cover estimate, since some definitions, such as FAO's forest definition, do not distinguish between natural and planted forest (Chazdon et al. 2016). Even if forest definitions were the same, global forest estimates derived from compilations of national data are significantly biased because the problems introduced by the different methods adopted by nations persist. Global assessments also fail to provide insights into forest cover change at the national or finer scales. At highly aggregate scales, reforestation and 
deforestation are offset and the magnitude of forest cover change is masked (Perz 2007).

These problems, of course, are not unique to global assessments. Studies of land-use and forest cover change at national, state, municipality or smaller scales also rely on a variety of methods including remote sensing (e.g. Rudel et al. 2002, Redo et al. 2012, Teixeira et al. 2009, Lira et al. 2012, Vaca et al. 2012, Schmitt-Harsh 2013, Timms et al. 2013, He et al. 2014, Schweizer \& Matlack, 2014, Yeo \& Huang 2013, Balthazar et al. 2015), field inventories (e.g. Rhemtulla et al. 2009), historical maps (e.g. Skalǒs et al. 2012) or census data (e.g. Baptista \& Rudel 2006, Baptista 2008). The fact that fine scale data are often not available for all localities of interest further complicates robust estimation of forest cover. Moreover, long-term time series of fine scale data are often not available. Finally, the combination of different forest cover datasets for creating a longer time series can provide temporal variations simply because of the bias introduced by the different estimation methods adopted.

Thus, any comparison or combination of forest cover estimates should be made cautiously because different methods introduce particular biases influencing forest cover estimates and analysis of forest cover trends. Ultimately, forest cover estimates should be chosen according to the aims and spatial and temporal scope of the study. For example, deforestation is a faster process and often affects larger areas than reforestation. Consequently, remote sensing images with coarse resolution can detect deforestation, but cannot detect reforestation in a short term.

Available forest cover data cannot address the specific aims of some ecological studies because they usually are developed for particular purposes (Lechner et al. 2012). As studies often rely on available data, biases related to methods and the possible limits of interpretation should be identified (Kleinn et al. 2000). Therefore, this study evaluates the discrepancies and the possible biases for three forest cover datasets of São Paulo, Brazil. As other countries or regions in the world, São Paulo's forest cover has increased after intense deforestation (Farinaci \& Batistella 2012, Lira et al. 2012, Ferraz et al. 2014, Silva et al. 2016, Molin et al. 2017). Identifying the mechanisms related to the forest cover change in the state depends on estimates that can detect forest losses and gains. Our goals are: 
(1) Determine if forest cover estimates obtained from censuses (IBGE) and from remote sensing images (IF and SOS data) are equivalent.

(2) Determine if differences: (a) between census and remote sensing estimates can be explained by municipalities' features as municipality area, census area, and the extent of protected lands; (b) between the two remote sensing datasets reflect variation in landscape configuration, that is, patch shape, total forest area, distance from the nearest neighbor and extent of edges.

(3) Determine if: (a) model depicting forest cover amount provides equivalent results when using different forest cover data sources (census or remote sensing datasets with distinct resolutions).

(4) Determine if the use of different data sources for complementing a time series results in equivalent trend estimates of forest cover change.

\section{METHODS}

STUDY AREA. - The state of São Paulo comprises 645 municipalities and covers 24.6 million hectares (3\% of Brazilian territory) (Fig.1). Currently, the state has 41.3 million people (21.6\% of the country's population, IBGE 2011$)$, and $96 \%$ of that population live in urban centers (IBGE 2011).

In the second half of $20^{\text {th }}$ century, economic development in São Paulo was promoted by agro-industry and by important interventions of Brazilian Government (e.g. Rural Credit Subsidy System and National Alcohol Program) which encouraged the expansion of export crops and agriculture modernization in the state (Baer 2008). During a short period of time, São Paulo shifted from a family-based agriculture to industrial agriculture. Meanwhile, the state presented a reduction in the deforestation rate of Atlantic Forest after 1985 (Fundação SOS Mata Atlântica 2016), and data from different sources showed forest cover net increase in São Paulo (Farinaci \& Batistella 2012, Lira et al. 2012, Ferraz et al. 2014, Silva et al. 2016, Molin et al. 2017).

Although forest cover in São Paulo has increased, only14\% of the Atlantic forest remains in São Paulo (Fundação SOS Mata Atlântica 2016), composed mainly of small fragments (Ribeiro et al. 2009) located in less suitable lands for agriculture (Teixeira et al. 2009, Lira et al. 2012, Silva et al. 2016). Because of this particular pattern, assessing forest cover change demands data on small spatial scales (e.g. 
municipality or finer scales) as reforestation and deforestation may be obscured in larger, more aggregated scales (e.g. state or national scales) (Perz 2007).

São Paulo has multiple sources of forest cover data from both census and remote sensing imagery. These data are collected frequently at the municipality scale so that it can be used to assess forest cover change at smaller spatial scale.

Furthermore, errors related to different forest classifications are reduced since forests in São Paulo belong either to the Atlantic forest or Cerrado Biomes and all the databases used in this study adopt similar definitions of forest cover.

FOREST COVER ESTIMATES. - To assess forest cover estimates of all the 645 São Paulo's municipalities, we used three sources of data: (1) the forest cover data from Brazilian National Agrarian Census Surveys performed in 2006 (IBGE - Brazilian Institute of Geography and Statistics 2006a); (2) data extracted from maps created by Forest Institute of São Paulo (IF) from 2008 and 2009 (SIFESP 2010), and (3) maps created by Fundação SOS Mata Atlântica (SOS) and the National Institute of Spatial Research (INPE) from 2005 to 2008 (SOS/INPE 2009). We use those datasets because they are freely available and provide data from a similar period (e.g. 2006 to 2009), allowing comparison among them. We also used forest cover estimates from IBGE census performed in 1960,1970, 1980 and 1996 to analyze changes in forest cover trend estimates when combining data from different sources to create a time series.

IBGE CENSUS DATA. - IBGE conducts the Agrarian Census Surveys (ACS) every ten years at the municipality scale (IBGE 2006b). IBGE classifies as "forest" old-growth forests, woodlands, shrubs and also secondary forests at the initial stage of succession. The ACS is conducted specifically in properties that are used for agriculture, forestry or aquaculture activities, relies on personal interviews with land owners or managers (IBGE 2006a) and data veracity is not verified. IBGE provides the census data at SIDRA database (http://www2.sidra.ibge.gov.br/). IBGE also conducts the census in Conservation Units of Sustainable Use, which are considered special units of sampling. In these cases, IBGE identifies and applies the census in the properties inside the Conservation Unit. Thus, only the forest cover within the property is quantified, but the forest cover that constitutes the Conservation Units is not included in IBGE estimates (IBGE/RJ, personal communication). 
SOS MAP. - Since the 1990s, Fundação SOS Mata Atlântica (SOS) and the National Institute of Spatial Research (INPE) assess forest cover of Atlantic Forest Biome by remote sensing imagery, and periodically release updated reports on deforestation rates for the entire Atlantic Forest Biome's (SOS/INPE 2016). SOS/INPE vegetation maps consider as forest remnants those climax patches or advanced stages of ecological succession (including mangroves and resting forests). For this study, we used forest cover data extracted from SOS/INPE's vegetation maps derived from Landsat 5, Landsat 7 and CBERS-2 images collected from 2005 to 2008, with a minimum mapping unit of five hectares and 30m pixel size (SOS/INPE 2009).

IF MAP. - IF also maps vegetation using remotely sensed images and periodically provides updated information through the Forest Inventory of the state. IF quantifies forest remnants and assesses forest cover dynamics for all municipalities (Kronka et al. 2005). Here, we used forest cover data extracted from IF's vegetation maps derived from ALOS (Advanced Land Observing Satellite) images collected between 2008 and 2009, with a minimum mapping unit of 0.25 hectares (SIFESP 2010) and $10 \mathrm{~m}$ pixel size, which allows detection of small patches and forests in early stages of succession (i.e. capoeira).

DETERMINING IF THE DIFFERENT FOREST COVER ESTIMATES ARE EQUIVALENT. - The percentage of forest cover in each municipality was calculated by dividing the estimated forest cover from IF and SOS/INPE maps by the municipality area. For the IBGE data, the percentage of forest cover was calculated by dividing the estimated forest area in each municipality by the census area (e.g. municipality area in which the census was taken). We fit linear regression models to assess if forest cover percent calculated from census data (IBGE), and remote sensing data (SOS/INPE and IF) are equivalent. We used $R$-squared $\left(R^{2}\right)$ to determine the strength of association between the datasets.

IDENTIFYING POSSIBLE BIAS SOURCES. - To assess the biases associated with each dataset, we fit linear regression models where differences between estimated forest cover among datasets are the response variable and potential bias sources are 
covariates (Tables $1 \& 2$ ). We considered three response variables (i) forest cover percentage estimated by IF minus forest cover percentage estimated by IBGE for each municipality (IF-IBGE); (ii) forest cover percentage estimated by SOS/INPE minus forest cover percentage estimated by IBGE for each municipality (SOS-IBGE); and (iii) forest cover percentage estimated by IF minus forest cover percentage estimated by SOS/INPE for each municipality (IF-SOS).

To assess the drivers of pairwise differences in forest cover (IF-IBGE and SOS-IBGE), we considered six predictor variables: municipality area (ha) (AREA), percentage of the municipality area in which the census was taken (CENS), and the percentage of the municipality area occupied by urban area (URB), Permanent Protection Areas (PPA), Conservation Unit of Integral Protection (CUIP) and Conservation Unit of Sustainable Use (CUSU). The rationale for selecting each predictor is shown in Table 1.

To estimate urban area extension, we used IF's remote sensing mapping from 2010 (SIFESP 2010). Permanent Protection Areas (PPA) are legally protected areas that aim to preserve streams and fragile areas such as steep slopes (Forest Code Federal Law No 4.771/1965). We considered CUSU and CUIP as two independent explanatory variables because CUIP are integrally protected by law (Federal Law $\mathrm{N}^{\mathrm{o}}$ 9985/2000), but particular properties are allowed in CUSU under specific conditions. The IBGE census is conducted in CUSU but not in CUIP. CUSU are usually occupied by small rural properties, except when CUSU in an Environmental Protection Area (EPA) which often comprise several municipalities (e.g. watersheds). We used the limits of protected areas provided by Forest Institute of São Paulo (IF) (SIFESP 2010) and by Brazilian List of Conservation Unit for state and national Conservation Unit, respectively. To assess if differences between IF and SOS estimates may be explained by landscape configuration, we used the following class descriptor metrics as explanatory variables (Table 2): total class area (CA), mean patch shape index (SHAPE), mean euclidean nearest-neighbor distance (ENN_MN), and total edge (TE). We also included the percentage of the municipality area occupied by PPA. The expected relationship between response and explanatory variables are shown in Table 2 . All the explanatory variables were calculated using the software Fragstats v 4.0 and were based on IF's native vegetation map (SIFESP 2010). 
Supplementary Information provides a description of each class metric used in this analysis (Table S1).

MODEL ANALYSIS USING DIFFERENT DATASETS. - To verify if model analyses using different datasets have similar results, we fit linear regression models and evaluate if the models fit forest cover data variation similarly. We expected that forest cover amount in São Paulo's municipalities is related to the amount of less suitable lands for agriculture (e.g. less humid soils) and legally protected areas (e.g. lands near river and streams, and fragile areas such as steep slopes) and Conservation Units in the municipalities. Therefore, we used as response variable percent of forest cover at municipality level and as explanatory variables soil water retention capacity (SWR), percent of PPA, percent of CUIP and percent of CUSU.

Response variables were log transformed for analyses. All explanatory variables in the regression models were standardized by subtracting the mean and dividing by one standard deviation (Gelman \& Hill 2007). Only variables with pairwise Pearson's Correlation Coefficient lower than 0.4 were included in the models. To select the explanatory variables that best explain the difference between estimates, we tested all the possible combination of explanatory variables using the function dredge from the package MuMIn (Barton 2016) and AIC for model selection (Burnham \& Anderson 2002). All analyses were performed using R Statistical software version 3.1.3 (R Development Core Team 2016).

COMPLEMENTING A TIME SERIES WITH DIFFERENT DATA SOURCES. - We calculated forest cover trends for each municipality of São Paulo using IBGE forest cover data for the years 1960, 1970, 1980, 1996 and 2006. We also created two different time series, replacing IBGE data of 2006 by IF data of 2010 or SOS data of 2008 . We fit linear regression models considering forest cover (IBGE data, IBGE + IF data or IBGE + SOS data) as response variable and year as an explanatory variable.

To compare the effect of combined data on forest cover trends, we plotted the regression slopes calculated using only IBGE data against the regression slopes calculated using combined data (IBGE + IF or IBGE + SOS) for each municipality. We used only municipalities with available data for all years of the time series. For better visualize data points on the graph, we plotted only slopes with significant $P$ - 
values for both trends, namely trends calculated using IBGE data and using combined data (IBGE + IF or IBGE + SOS), or for at least one of them. Supplementary Information provides a graph presenting the slopes calculated for all municipalities, including those with non-significant $P$-values (Fig. S1) .

\section{RESULTS}

COMPARISON OF FOREST COVER ESTIMATES USING THREE DATASETS. - Forest cover estimated from IF compared to SOS presented higher similarity $\left(R^{2}=0.8577\right.$; $P<<0.0001)$ (Fig. S2), followed by IF compared to IBGE $\left(R^{2}=0.7145, P<<0.0001\right)$. On the other hand, forest cover estimates from IBGE and SOS presented the lower similarity $\left(R^{2}=0.4976 ; P<<0.0001\right)$.

Forest cover estimates from IF were higher than SOS and IBGE estimates for $84.65 \%$ (Fig. 2A) and $62.17 \%$ (Fig. 3A) of the 645 municipalities, respectively. In $69.30 \%$ of the municipalities, IBGE estimated higher forest cover than SOS (Fig. 2B

IDENTIFYING POSSIBLE BIAS SOURCES. - Regression results indicate that the difference between census and remote sensing estimates (IF-IBGE and SOS-IBGE) is related to municipality characteristics. However, the model depicting the difference between SOS and IBGE presented low power explanation $\left(R^{2}=0.006\right)$ (Table 3$)$.

Municipalities with a higher percentage of urban area exhibited smaller differences between forest cover estimates derived from IF maps and IBGE census (Table 3, Fig. 4A), contradicting our expectation (Table. 1). As expected (Table 1), the larger the extent of protected areas, either in PPA, CUSU, CUIP, the larger the difference between IF and IBGE estimates. Municipality area (AREA) and municipality area in which the census was conducted (CENS) are negatively, but nonsignificantly, related to the difference between IF and IBGE (Fig. 4A).

As expected, differences between SOS's remote sensing estimates and IBGE's were greater in municipalities with a larger extent of CUIP, and smaller in those with a larger municipality area and a larger amount of land allocated to urban land use (Table 3, Fig. 4B), contradicting our expectations (Table 1). Percent of Conservation Unit of Sustainable Use (CUSU) is positively, but non-significantly, related to the difference between SOS and IBGE (Fig. 4B). 
The difference in forest cover estimates derived from the two remote sensing estimates (IF-SOS) was related to landscape configuration (Table 3). As we hypothesized (Table S2), differences between the two remotely sensed estimates were higher in more fragmented lands evidenced by the positive association between the magnitude of the discrepancies and landscape fragmentation metrics, including total amount of edge (TE), more complex patch geometry (SHAPE) and total class area (CA) (Table 3 \& Fig. 4C). However, the difference was smaller in municipalities with larger mean distance to nearby forest patches (ENN_MN), contradicting our expectation (Table 3, S2 \& Fig. 4C). Differences were also greater for municipalities with larger areas in PPAs, as we hypothesized (Table 3, S2 \& Fig. 4C).

EFFECTS OF DIFFERENT DATASETS ON MODEL RESULTS. - Models results are similar when using IF's and IBGE' estimates, but model better explains IF's $\left(R^{2}=0.5691\right)$ data variability than SOS's $\left(R^{2}=0.42\right)$ and IBGE's $\left(R^{2}=0.3113\right)$ data variability (Fig. 5, Table 4). As we expected (Table S2), percent of Permanent Protection Areas (PPA) and percent of Conservation Units of Integral Protection (CUIP) and Sustainable use (CUSU) are positively related to forest cover percent estimated by SOS, IF and IBGE (Fig. 5A-5C, Table 4). As expected (Table S2), soil water retention capacity (SWR) is negatively related to forest cover percent estimated by IF and IBGE but has no effect on forest cover percent estimated by SOS (Fig. 5A-5C, Table 4).

EFFECTS OF COMBINED TIME SERIES ON FOREST COVER TRENDS. - Trends calculated with IBGE data and with combined data (IBGE+SOS or IBGE+IF) are equivalent for most municipalities - colorful dots in quadrants I and III (Fig. 6A \& 6B) - but some municipalities presented contradictory trends - colorful dots in quadrant II and quadrant IV (Fig. 6A \& 6B).

IBGE data combined with SOS data provided negative trend (deforestation), while IBGE data provided positive but non-significant trends (red dots, quadrant II) for four municipalities (Fig. 6A). For only one municipality, IBGE data provided a positive significant trend (forest gains) while IBGE data combined with SOS data provided non-significant negative trend (yellow dot, quadrant II) (Fig. 6A). For two municipalities IBGE data provided negative trends, while combined data provided positive trends (quadrant IV) (Fig. 6A). We included in these analyses only 
municipalities that presented complete time series (443 municipalities). We plotted only the slopes (e.g. regression coefficients) of the municipalities that presented significant trends $(P$-value $<0.05)$ for better visualizing the colorful dots. Figure S1 shows the results of the 443 municipalities tested.

IBGE data combined with IF data provided positive non-significant trends, while IBGE data provided significant negative trends, or deforestation (yellow dots, quadrant IV) (Fig. 6B) for six municipalities.

\section{DISCUSSION}

We detected high correlation of forest cover between different estimation methods. However, municipality features and spatial arrangement of native vegetation can lead to discrepancies between estimates based on census and remoting sensing images. These biases should be considered when choosing a method given the aim of the study (Kleinn et al. 2002). Moreover, using data from different sources to create a larger time sequence for forest cover change studies may also lead to contradictory results in some cases.

\section{EFFECTS OF MUNICIPALITY FEATURES ON DIFFERENCES BETWEEN FOREST COVER} ESTIMATES DERIVED FROM CENSUS AND REMOTE SENSING METHODS

Municipality features, such as the extent of protected and urban areas, can introduce bias in forest cover estimates. IBGE only quantifies forests in Permanent Protection Areas (PPA) that are located within rural private properties what underestimates forest cover and increases the differences between IF and IBGE.

On the other hand, PPA have no effect on the differences between SOS and IBGE possibly because SOS also underestimates forest cover in those areas. Smaller and linear patches or vegetation in early stages of succession, as those in PPA of São Paulo (Rodrigues et al. 2011), may not be captured by remote sensing images of coarser resolution (Lechner et al. 2009). Therefore, SOS maps do not delineate narrow polygons or polygons with low arboreal vegetation densities because of difficulties in classifying these areas as forest patches during image interpretation (SOS/INPE, 2009), what underestimates forest cover in São Paulo’s municipalities.

CUIP (Conservation Units of Integral Protection) are protected by federal law (Federal Law No 9985/2000) which does not allow properties within these 
conservation units, besides some CUIP are not regularized and still encompass private properties. IBGE does not quantify forest cover within CUIP, leading to higher differences between IF-IBGE and SOS-IBGE. Therefore, the greatest differences between IF/SOS and IBGE belong to municipalities near São Paulo’s coast, that shelter the largest mosaics of Conservation Units and largest remnants of Atlantic Forest Biome (see Fig. 3).

Larger CUSU (Conservation Units of Sustainable Use) increase the differences between IF and IBGE, as IBGE underestimates forests within CUSU. IBGE does not quantify the entire forest area in CUSU, but only the forests inside the properties within CUSU which are usually small (IBGE/RJ, personal communication); except in Environmental Protection Areas (EPA), a special case of CUSU, that cover extensive regions and encompass several municipalities protecting watersheds, for instance. On the other hand, CUSU has no effect on the differences between SOS and IBGE, possibly because SOS underestimates forests in EPA. As forest cover in EPA is highly fragmented, SOS does not detect part of the small and/or narrow patches underestimating forest in municipalities with large EPA.

Municipalities with large urban areas had lower differences in IF-IBGE and SOS-IBGE. These patterns could be related to the small number and small extent of forest patches in urban areas. Accurate identification of specific land uses in urban areas demands very high spatial resolution (e.g. $3 \mathrm{~m}$ ), because these areas usually exhibit fine-scale spatial heterogeneous land cover (Herold et al. 2002). IF's (10m) and SOS's (30m) spatial resolutions do not allow the classification of the few and extreme small patches in urban areas, possibly leading to lower discrepancies between the metrics and IBGE data.

Large municipalities presented lower differences between SOS and IBGE estimates, possibly because of SOS's coarser resolution. As São Paulo's forest cover is constituted mainly by very small patches (Ribeiro et al. 2009), larger municipalities possibly have more isolated patches which may not be quantified by SOS, decreasing the difference between SOS and IBGE.

\section{EFFECTS OF LANDSCAPE CONFIGURATION ON DIFFERENCE BETWEEN IF'S AND SOS'S} FOREST COVER ESTIMATES 
Our results indicate that discrepancies between forest cover estimates from different spatial resolution images are influenced by different landscape structure characteristics.

High total forest area (CA) in the municipality is related to higher differences between IF and SOS, indicating that SOS may be underestimating the forest cover in municipalities with more remnants. Forest cover in most São Paulo's municipalities are highly fragmented and composed of very small patches (Ribeiro et al. 2009) which can be underestimated by coarser spatial resolution maps (Soares et al. 2008), such SOS maps. For the same reason, large Permanent Protection Areas (PPA), resulting in more linear patches along rivers (high SHAPE values) and longer edges (high total edge length) increase the differences between IF and SOS. PPA are protected areas, but not necessarily forested. Usually, these areas are degraded and have small linear patches (Rodrigues et al. 2011) which may not be detected by coarser resolution maps (Lechner et al. 2009). Similarly, highly complex (i.e. high SHAPE) and narrow elongated patches (i.e. high TE) are not detected, or only partially detected, by SOS maps what underestimate forest cover in the municipalities.

We expected that differences between IF and SOS would be greater where patches are isolated (Table 3), but our results showed the contrary. This pattern may be related to patches' location. Forest cover in São Paulo is constituted mainly by small patches which tend to be concentrated in less suitable lands for agriculture (Silva et al. 2007, Teixeira et al. 2009, Silva et al. 2016), what possibly isolate groups of small patches. The difference between IF and SOS decreases because groups of small patches can be mapped as one single large by coarse resolution mappings (Millington et al. 2003).

These differences among forest cover estimated by IF, SOS and IBGE are related to their different aims. Agricultural censuses, as IBGE census, aim to monitor socioeconomic aspects of agriculture; hence censuses are applied only in rural properties, what can introduce considerable variability in forest cover data (Kleinn et al. 2002). Nevertheless, agricultural censuses are important data for assessing land-use effects on forest cover, since they also provide periodically socioeconomic data of all farms in the country. On the other hand, SOS aims to detect forest loss at a broader scale and provides periodically reliable estimates of deforestation rates of Atlantic forest biome, which encompasses seventeen Brazilian States (SOS/INPE 2009). 
Whereas, SOS maps may not be suitable for studies that demand finer resolution maps (e.g. $10 \mathrm{~m}$ pixel or less), as assessing corridors or landscape connectivity for species able to use narrow forest corridors such as hedgerows (Lechner et al. 2009), estimating forest carbon sinks (Moscorro et al. 2015) or forest cover changes at finer scales (Achard et al. 2010). These datasets particularities need to be considered when choosing one among available data since the discrepancies between forest cover estimates reflect on analyses results.

\section{EFFECTS OF DIFFERENT FOREST COVER ESTIMATES ON MODEL RESULTS AND TRENDS OF} FOREST COVER CHANGE

Models using IF and IBGE data presented congruent results, but the model better explains forest cover variability when using IF data as the response variable. Using IF or IBGE data, forest cover amount in São Paulo was related to the amount of less suitable lands for agriculture (e.g. less humid lands) and protected lands (e.g. CUSU, CUIP and PPA - lands near streams and steep slopes) in the municipalities. CUIP was not expected to influence forest cover estimated by IBGE because private properties are not allowed within CUIP. However, some CUIP still have particular properties where the census is applied, part of these properties is legal but waits for land regularization. Moreover, larger CUIP are located in regions with steeper slopes and lower agricultural potential, which also lead to the high amount of forest cover inside properties (Calaboni et al. 2017, in preparation).

When using SOS data as the response variable, forest cover amount in São Paulo is related to the amount of protected areas (CUSU, CUIP, and PPA), but it is not related to the amount of less suitable lands for agriculture, contradicting our expectation. SOS maps do not detect part of the very small and linear patches which are most in private lands (Ribeiro et al. 2009), besides SOS maps the entire state of São Paulo as IF. Therefore, low quality of land for agriculture is not a predictor of forest cover amount estimated by SOS.

These differences between models results are related to the biases we presented in the previous analyses (see Table 3, Fig. 4). IF maps the entire state including small, complex patches and also early stages of succession, therefore the model depicting forest cover using IF data as response variable presented higher explanatory power $\left(R^{2}=0.5691\right)$ than $\operatorname{SOS}\left(R^{2}=0.42\right)$ and IBGE $\left(R^{2}=0.31\right)$ models. 
For the same reason, forest cover trends calculated using combined datasets provided contradictory trends for some municipalities. When using IF data for complementing IBGE time series, some municipalities presented positive trends but trends are negative when using only IBGE data. As IBGE tends to underestimate forest cover comparing to IF data, IF data can provide mistaken information about forest gains. On the other hand, SOS tends to underestimate forest cover comparing to IBGE, then combining IBGE data with SOS data lead to negative trend while IBGE data indicate forest gains for the same period.

IBGE census only quantifies the forest cover inside private properties, therefore underestimates forests in the municipalities (Table 3). Hence, the model using IBGE data as response variable presented the lower power of explanation comparing to IF model. However, IBGE model was plausible to explain forest cover amount in São Paulo. Accordingly, forest cover data provided by IBGE census is a very important data source and has been used in forest cover and/or land cover change studies in Brazil (e.g. Baptista \& Rudel 2006, Baptista 2008, Barretto et al. 2013, Lapola et al. 2014).

As the model using IBGE data the model using SOS data also presented lower power of explanation comparing to IF, possibly because SOS maps do not capture very small patches. Nevertheless, these results do not disqualify SOS reports, since coarser resolution maps are suitable for broad-scale studies as assessing forest cover change at national and regional scales (Wessel et al. 2004, Achard et al. 2010).

Our results emphasize that forest cover data should be chosen according to the study aims since they are developed for specific purposes; and then could not reliably address the ecological phenomena to be assessed (Lechner et al. 2012). However, estimates can be very useful if the problems related to methods and limits of interpretation are spelled out (Kleinn et al. 2000).

\section{CONCLUSION}

IF, IBGE and SOS forest cover datasets are considerable congruent, but municipality features and landscape configuration introduce important biases which influence analysis results and may mislead the conclusions.

Forest cover datasets have been remarkably requested for assessing forest cover change and ecosystem services decline around the world. Often, however, 
availability is one important criterion for choosing a forest cover data. Therefore, forest cover data should be evaluated for their suitability to study purposes. Inappropriate forest cover data, or a combination of distinct databases, can lead to misleading results regarding trends in forest cover changes and their association with socioeconomic and environmental factors.

\section{ACKNOWLEDGMENTS}

Adriane Calaboni was funded by the Brazilian Ministry of Education (CAPES) doctoral studentship. We would like to thank Dr. Jefferson Mariano (IBGE/SP) and Antônio Carlos Simões Florido (IBGE/RJ) for gently helping authors with SIDRA database and Brazilian National Agrarian Census Survey data.

\section{LITERATURE CITED}

Achard, F., H. Stibig, H. D. Eva, E. J. Lindquist, A. Bouvet, O. Arino and P. MAYAUX. 2010. Estimating tropical deforestation from Earth observation data. Carbon Management 1:271-287.

Aide, T.M., M.L. Clark, H.R. GraU, D. LóPes-CARr, M.A. LeVy, D. Redo, M. Bonilla-Moheno, G. Riner, M.J. ANDRAdE-NúÑEZ, and M. MuÑIZ. 2013. Deforestation and Reforestation of Latin America and the Caribbean (20012010). Biotropica 45: 262-271.

BAER, W. 2008. The Brazilian growth and development Sixth Edit. Lynne Rienner Publishers, Boulder, CO.

BalthaZAR, V., V. VANACKer, A. Molina, and E. F. LAMBin. 2015. Impacts of forest change on ecosystem services in high Andean mountains. Ecol. Indic. 48: 6375.

BAPTISTA, S.R. 2008. Metropolitanization and forest recovery in Southern Brazil: a multiscale analysis of Florianópolis City-Region, Santa Catarina State, 1970 to 2005. Ecol. Soc. 13:2.

BAPTISTA, S.R., and T.K. RUDEL 2006. A re-emerging Atlantic forest? Urbanization, industrialization and the forest transition in Santa Catarina, southern Brazil. Environ. Conserv. 33:195-202. 
Barretto, A. G. O. P., G. Berndes, G. SparoveK, and S. Wirsenius. 2013. Agricultural intensification in Brazil and its effects on land-use patterns: An analysis of the 1975-2006 period. Glob. Chang. Biol. 19: 1804-1815.

BARTON, K. 2016. MuMIn: Multi-Model Inference. Available at: http://mumin.rforge.r-project.org/.

BuRNHAM, K. P., and D. R. ANDERSON. 2002. Model selection and multimodel inference: a practical information-theoretic approach Second Edi. SpringerVerlag, New York.

Calaboni, A., L.R. Tambosi, A.I. Igari, J. Farinaci, J.P. Metzger, and M. URIARTE. 2017. The Forest Transition in São Paulo, Brazil: historical patterns and putative drivers. 2017. Manuscript in preparation.

Chazdon, R.L., P.H.S. Brancalion, L. Laestadius, A. Bennett-Curry, K. Buckingham, C. Kumar, J. MOLL-RoceK, I.C.G. VIERA, and S.J. WiLSON. 2016. When forest is a forest? Forest concepts and definitions in the era of forest and landscape restoration. Ambio 45:538-550.

Costa, R.L., J.A. Prevedello, B.G. DE SouZA, and D.C. Cabral. 2017. Forest transition in tropical landscapes: a test in the Atlantic Forest biodiversity hotspots. Appl. Geogr. 82:93-100.

CRK, T., M. URIARTE, F. CORSI, and D. FLYNN. 2009. Forest recovery in a tropical landscape: What is the relative importance of biophysical, socioeconomic, and landscape variables? Landsc. Ecol. 24: 629-642.

FARINACI, J.S., and M. BATISTELLA. 2012. Variação na cobertura vegetal em São Paulo: um panorama do conhecimento atual. Rev. Árvore 36: 695-705.

Ferraz, S.F.B., K.M.P.M.B. Ferraz, C.C. CASSIANO, P.H.S. BranCALION, D.T.M. LuZ, T.N. AzEvedo, L. R. TAmbosi, and J.P. MetzGer. 2014. How good are tropical forest patches for ecosystem services provisioning? Landscape Ecol. 29:187-200.

Food And Agriculture OrganiZATION OF THE United NATIONS. Global Forest Resources Assessment 2010: Main Report. Roma: FAO, 2010. 191p. Available at www.fao.org/docrep/013/i1757e/i1757e.pdf. Access in 05/04/2015.

Food AND AGRiculture OrganiZATION OF THE United NATIONS (FAO), EUROPEAN COMMISSION JOINT RESEARCH CENTRE (JRC). 2012. Global forest land-use 
change 1990-2005. FAO: Rome, 53p. Available at www.fao.org/docrep/017/i3110e/i3110e.pdf Access in 05/04/2015.

Foley, J. A., R. Defries, G. P. Asner, C. Barford, G. Bonan, S. R. CARpenter, F. S. Chapin, M. T. Coe, G. C. DAily, H. K. GibBs, J. H. Helkowski, T. Holloway, E. A. Howard, C. J. Kucharik, C. Monfreda, J. A. Patz, I. C. Prentice, N. RamankUtTy, and P. K. SnYDER. 2005. Global consequences of land use. Science 309: 570-4.

FundaÇão SOS Mata AtlâNTICA, Instituto NaCiOnAl de PESQUiSAs EsPaCiais INPE. Atlas dos Remanescentes Florestais da Mata Atlântica: Período 20142015. 2016. SOS: São Paulo. Available at http://mapas.sosma.org.br/dados/\#. Access in 02/04/2017.

Fundação SOS Mata AtlÂNTICA, Instituto Nacional de Pesquisas EsPaCiais INPE. Atlas dos Remanescentes Florestais da Mata Atlântica: Período 20052008. 2009. SOS: São Paulo. Available at http://mapas.sosma.org.br/dados/\#. Access in 03/20/2015.

GEIST, H. J., and E. F. LAMBIN. 2002. Proximate causes and underlying driving forces of tropical deforestation. Bioscience 52: 143-150.

Gelman, A., and J. HILl. 2007. Data analysis using regression and multilevel/hierarchical model. First Edt. Cambridge University Press, Cambridge, UK.

GraINGER, A. 2008. Difficulties in tracking the long-term global trend in tropical forest area. PNAS 105: 818-823

HE, J., R. LANG, J XU. 2014. Local dynamics driving forest transition: insights from upland villages in Southern China. Forest. 5: 214-233.

Herold, M., S. Joseph and C.K. Clarke. 2002. The use of remote sensing and landscape metrics to describe structures and changes in urban land uses. Environ. Plan.A 34:1443-1458.

Holmgren, P., and R. Persson. 2002. Evolution and prospects of global forest assessments. Unasylva. 53:3-9.

IBGE. 2011. Características da população e dos domicílios: resultados do universo.

Rio de Janeiro. Available at:

http://www.ibge.gov.br/home/estatistica/populacao/censo2010/default.shtm.

IBGE. 2006a. Censo Agropecuário: Brasil, Grandes Regiões e Unidades da 
Federação. IBGE: Rio de Janeiro, 777p. Available at

http://www.ibge.gov.br/home/estatistica/economia/agropecuaria/censoagro/def ault.shtm Access in 04/20/2015.

IBGE. 2006b. Estatísticas do século XX. IBGE: Rio de Janeiro, 557p. Available at http://seculoxx.ibge.gov.br/ . Access in 04/20/2015.

KLEINN, C., L. CoRrales, and D. Morales. 2002. Forest area in Costa Rica: a comparative study of tropical forest cover estimates over time. Environ. Monit. Assess. 73:17-40.

KronKA, F.J.N., M.A. NALON, C.K. MATSUKUnA, et al. 2005. Inventário florestal da vegetação natural do estado de São Paulo. SMA: São Paulo. 200p. Available at http://www.florestalterraverde.com.br/artigos_baixar/ifVegnaturalsp_parte1.pd f Access in 04/04/2015.

LAMBIN, E. F., and P. MEYFROIDT. 2010. Land use transitions: Socio-ecological feedback versus socio-economic change. Land Use Policy 27: 108-118.

Lapola, D. M., L. A. Martinelli, C.A. Peres et al. 2014. Pervasive transition of the Brazilian land-use system. Nat. Clim. Chang. 4: 27-35.

LeChner, A.M., S. Alfred, S. D. Jones, and J.G. Ferwed. 2009. Remote sensing of small and linear features: quantifying the effects of patch size and length, grid position and detectability on land cover mapping. Remote Sens. Environ. 113:2194-2204.

LeChNER, A. M., W.T. LANGFord, S.A. BeKESSY, and S.D. Jones. 2012. Are landscape ecologists addressing uncertainty in their remote sensing data? Landscape Ecol. 27:1249-1261.

LELOUP, M. 1947. The world's dilemma: more timber, more conservation. Unasylva, 1. Available at http://www.fao.org/docrep/x5340e/x5340e05.htm Access in 04/04/2015.

LIRA, P.K., L.R. TAMBOSI, R.M. EwERS, and J.P. METZGER. 2012. Land-use and landcover change in Atlantic forest landscape. Forest Ecol. Manag. 278:80-89.

Millington, A. C., X. M. Velez-Liendo, and A. V. Bradley. 2003. Scale dependence in multitemporal mapping of forest fragmentation in Bolivia: implications for explaining temporal trends in landscape ecology and applications to biodiversity conservation. ISPRS J.

Photogramm. Remote Sens. 57:289-299. 
Molin, P.G., S.E. Gergel, B.S.SoARES-FILHO, and S.F.B. FerRAZ. 2017. Spatial determinants of Atlantic Forest loss and recovery in Brazil. Landsc. Ecol. $32: 857-870$.

Moscorro, V. S., N. C. CoOPS, W. A. KurZ, and M. Olguín. 2015. Choice of satellite imagery and attribution of changes to disturbance type strongly affects forest carbon balance estimates. Carbon Balance Manage. 10:30.

PERZ, S.G. 2007. Grand theory and context-specificity in the study of forest dynamics: Forest Transition Theory and other directions. Prof. Geogr. 59:105-114.

R Development Core TeAm. 2016a. R: A language and environment for statistical computing. Available at: https://www.r-project.org/

R Development Core Team. 2016b. The R Stats Package. Available at: https://stat.ethz.ch/R-manual/R-devel/library/stats/html/00Index.html

Redo, D.J., H.R. GraU, T.M. Aide, and M.L. Clark. 2012. Asymmetric forest transition driven by the interaction of socioeconomic development and environmental heterogeneity in Central America. PNAS 109:8839-8844.

Rhemtulla, J.M., D.J. Mladenoff, and M.K. Clayton. 2009. Legacies of historical land use on regional forest composition and structure in Wisconsin, USA (mid-1800s-1930's-2000's). Ecol. Appl. 19:1061-1078.

Ribeiro, M.C., J.P. MetzGer, A.C. MARTEnsen, F.J. Ponzoni, and M.M. Hirota. 2009. The Brazilian Atlantic Forest: how much is left, and how is the remaining forest distributed? Implications for conservation. Biol. Conserv. 142:1141-1153.

Rodrigues, R.R, S. GANDOlFi, A.G. NAVE, J. Aronson, and T.E. BARreto. 2011. Large-Scale ecological restoration of high-diversity tropical forests in SE Brazil. Forest Ecol. Manag. 261:1605-1613.

Rudel, T.K., D. BATES, and R. MACHINGUIASHI. 2002. A tropical forest transition? Agricultural change, out-migration, and secondary forests the Ecuadorian Amazon. Ann. Asso. Am. Geogr. 92:87-102.

SCHMitT-HARSH, M. 2013. Landscape change in Guatemala: driving forces of forest and coffee agroforest expansion and contraction from 1990 to 2010. Appl. Geogr. 40: 40-50.

SCHWEIZER, P.E., and G. R. MATLACK. 2014. Factors driving land use change and forest distribution on the coastal plain of Mississipi, USA. Landscape Urban 
Plan. 121:55-64.

Silva, W. G., J. P. MetzGer, S. SimõeS, and C. Simonetti. 2007. Relief influence on the spatial distribution of the Atlantic Forest cover on the Ibiúna Plateau, SP. Brazilian J. Biol. 67: 403-411.

Silva, R. F. B., M. Batistella, and E. F. Moran. 2016. Drivers of land change: human-environment interactions and the Atlantic forest transition in the Paraíba Valley, Brazil. Land Use Policy 58: 133-144.

SOARES, D.M., L.S. GALVÃO, and A.R. ForMAGGIO. 2008. Crop area estimate from original and spatial resolution data and landscape metrics. Sci. Agric. 65:459467.

Sistema DE INFORMAÇÕES FloRESTAIS do Estado DE SÃo PAUlO - SIFESP. 2010. Available at http://www.iflorestal.sp.gov.br/sifesp/ Access 05/20/2015.

SkalǑs, J., B. EngstovÁ, I. TRPÁKOVÁ, M. ŠAnTRŮČKOVÁ, and V. PoDRÁSZKÝ. 2012. Long-term changes in forest cover 1780-2007 in central Bohemia, Czech Republic. Eur. J. For. Res. 131:871-884.

StOKSTAD, E. 2001. U.N. report suggests slowed forest losses. Science. 291:2294.

TeiXeira, A.M.G., B. SoAres-Filho, S.R. Freitas, and J.P. MetzGer. 2009.

Modeling landscape dynamics in an Atlantic rainforest region: implications for conservation. Forest Ecol. Manag. 257:1219-1230.

TIMMS, B.F., J. HAYES, and M. MCCRACKEN. 2013. From deforestation to reforestation: applying the forest transition to the Cockpit Country of Jamaica. Area 45.1: 77-87.

VACA, R.A., D.J. Golicher, L. CAYUela, J. Hewson, and M. Steininger. 2012. Evidence of incipient forest transition in Southern Mexico. PLOS ONE 7: e42309.

Yackulic, C. B., M. FAgan, M. Jain, Y. Lim, M. Marlier, R. Muscarella, P. ADAME, R. DeFries, and M. URIARTE. 2011. Biophysical and Socioeconomic Factors Associated with Forest Transitions at Multiple Spatial and Temporal Scales. Ecol. Soc. 16: 15.

YeO, I., C. HuAng. 2013. Forest dynamics in Mississipi, USA: a hybrid statistical and geospatial analysis. Reg. Environ. Change 13:583-599. 
TABLE 1. Explanatory variables used to model the difference between estimates derived from remotely sensed data and IBGE's census estimates. We also show rationale for hypothesized relationship between the response (the difference between two forest cover estimates) and explanatory variables.

\begin{tabular}{|c|c|c|}
\hline $\begin{array}{c}\text { Explanatory } \\
\text { Variables }\end{array}$ & $\begin{array}{l}\text { Hypothesized } \\
\text { Relationship }\end{array}$ & Rationale \\
\hline $\begin{array}{l}\text { Municipality } \\
\text { area (AREA) }\end{array}$ & + & $\begin{array}{l}\text { The increase of municipality area can increase } \\
\text { the probability of error in the IBGE's estimates } \\
\text { because forests out of agrarian census surveys } \\
\text { are not quantified by IBGE. }\end{array}$ \\
\hline $\begin{array}{l}\text { Percentage of } \\
\text { the } \\
\text { municipality } \\
\text { area in which } \\
\text { the census was } \\
\text { taken (CENS) }\end{array}$ & - & $\begin{array}{l}\text { The bigger the census area in the municipality, } \\
\text { the higher the percentage of municipality area } \\
\text { in which the census was conducted and the } \\
\text { lower the difference between IF's/SOS's and } \\
\text { IBGE's estimates }\end{array}$ \\
\hline $\begin{array}{l}\text { Percentage of } \\
\text { the } \\
\text { municipality } \\
\text { occupied by } \\
\text { urban areas } \\
\text { (URB) }\end{array}$ & + & $\begin{array}{l}\text { The larger the urban area in the municipality, } \\
\text { the higher the forest percentage in the } \\
\text { municipality that is not quantified by IBGE } \\
\text { (e.g., public parks). }\end{array}$ \\
\hline $\begin{array}{l}\text { Percentage of } \\
\text { Permanent } \\
\text { Protection } \\
\text { Areas (PPA) }\end{array}$ & $+/-$ & $\begin{array}{l}\text { PPAs in São Paulo are composed of very small } \\
\text { and scattered patches. These are considered by } \\
\text { IF, but landowners can overestimate or } \\
\text { underestimate the forest area. Very small and } \\
\text { scattered patches may not be quantified by } \\
\text { SOS, but they can be considered as a single } \\
\text { large patch if close to each other. A higher } \\
\text { percent of PPAs in the municipality can } \\
\text { increase or decrease the difference between } \\
\text { SOS's and IBGE's estimates. }\end{array}$ \\
\hline $\begin{array}{l}\text { Percentage of } \\
\text { Conservation } \\
\text { Units of } \\
\text { Integral } \\
\text { Protection } \\
\text { (CUIP) }\end{array}$ & + & $\begin{array}{l}\text { CUIP are not inhabited according to the law so } \\
\text { these areas are not surveyed by IBGE, } \\
\text { increasing the difference between IF's/SOS's } \\
\text { and IBGE's estimates }\end{array}$ \\
\hline $\begin{array}{l}\text { Percentage of } \\
\text { Conservation } \\
\text { Units of } \\
\text { Sustainable } \\
\text { Use (CUSU) }\end{array}$ & $+/-$ & $\begin{array}{l}\text { CUSU are inhabited, but IBGE does not } \\
\text { consider the forest cover of the entire CUSU in } \\
\text { its estimates; considering only forests inside } \\
\text { rural properties, which are usually small. } \\
\text { However, Areas of Environmental Protection } \\
\text { (EPA), a special case of CUSU, usually occupy } \\
\text { several municipalities and the census is } \\
\text { conducted normally. }\end{array}$ \\
\hline
\end{tabular}


TABLE 2. Explanatory variables used in the model for the difference between IF's estimates and SOS's estimates

\begin{tabular}{lcl}
\hline \multicolumn{1}{c}{$\begin{array}{c}\text { Explanatory } \\
\text { variables }\end{array}$} & $\begin{array}{c}\text { Hypothesized } \\
\text { Relationship }\end{array}$ & \multicolumn{1}{c}{ Rationale } \\
\hline $\begin{array}{l}\text { Percentage of } \\
\text { municipality area } \\
\text { occupied by }\end{array}$ & + & $\begin{array}{l}\text { In São Paulo, the APPs are composed of very } \\
\text { small and elongated patches that might not be } \\
\text { quantified by SOS }\end{array}$ \\
$\begin{array}{l}\text { Protection Areas } \\
\text { (PPA) }\end{array}$ & + & $\begin{array}{l}\text { Since São Paulo forest cover is composed } \\
\text { mainly of very small patches, the higher CA } \\
\text { the greater the number of small patches not } \\
\text { quantified by SOS }\end{array}$ \\
$\begin{array}{l}\text { Total class areas } \\
\text { CA) }\end{array}$ & + & $\begin{array}{l}\text { Small linear patches may not be detected by } \\
\text { SOS because of its lower spatial resolution }\end{array}$ \\
\hline $\begin{array}{l}\text { Total Edge (TE) } \\
\text { Mean euclidean } \\
\text { nearest-neighbor } \\
\text { distance (ENN_MN) }\end{array}$ & + & $\begin{array}{l}\text { Small isolated patches are not detected by } \\
\text { SOS underestimating forest cover and } \\
\text { increasing the difference. Small patches close } \\
\text { to each other can be considered as one large } \\
\text { patch by SOS leading to forest cover } \\
\text { overestimation and decreasing the difference. }\end{array}$ \\
\hline & & SOS does not quantify small linear patches \\
\hline $\begin{array}{l}\text { Mean patch shape } \\
\text { index (SHAPE) }\end{array}$ & + &
\end{tabular}


TABLE 3. Models selected for the differences IF-IBGE, SOS-IBGE, and IF-SOS, according to Akaike's Information Criterion (AIC) and model validation by $R$-squared $\left(R^{2}\right)$ statistics.

\begin{tabular}{llcccc}
\hline & Explanatory variables & AIC & Weight $^{\S}$ & $R^{2 *}$ & $P$-value** \\
\hline IF- & PPA - AREA - URB - CENS + CUIP + & -1182 & 0.466 & 0.2938 & $<<0.0001$ \\
IBGE & CUSU & & & & \\
SOS- & - AREA - URB + CUIP + CUSU & -889.4 & 0.327 & 0.0679 & $<<0.0001$ \\
IBGE & & & & & \\
IF-SOS & PPA + CA - ENN_MN + SHAPE + TE & 510.3 & 1 & 0.5442 & $<<0.0001$ \\
\hline
\end{tabular}

${ }^{\S}$ Weight of evidence that the presented model is the best, given the data and candidate models

* $R$-squared is the proportion of the response variable variation that is explained by the model

**Significant $P$ value $(P<0.05)$ indicates a significant relationship between explanatory and response variables 
TABLE 4. Best models depicting forest cover amount in São Paulo's municipalities using IF's, SOS's and IBGE's estimates (\%FC) as response variables. Model selection was performed according to Akaike's Information Criterion (AIC) and model validation by $R$-squared ( $\left.\mathrm{R}^{2}\right)$ statistics.

\begin{tabular}{llcccc}
\hline & \multicolumn{1}{c}{ Models } & AIC & Weight $^{\S}$ & $R^{2^{*}}$ & $\begin{array}{c}P_{-} \\
\text {value }^{* *}\end{array}$ \\
\hline IF & $\begin{array}{l}\text { \%FC } \sim \text { PPA- SWR + CUSU + } \\
\text { CUIP }\end{array}$ & 678.8 & 1 & 0.5691 & $<0.0001$ \\
SOS & $\%$ FC $\sim$ PPA + CUSU + CUIP & 864.5 & 0.6331 & 0.42 & $<0.0001$ \\
IBGE & $\%$ FC PPA - SWR +CUSU+ CUIP & 871.4 & 1 & 0.3113 & $<0.0001$ \\
\hline
\end{tabular}

\footnotetext{
${ }^{\S}$ Weight of evidence that the presented model is the best, given the data and candidate models

${ }^{*} R$-squared is the proportion of the \%FC variation that is explained by the model

${ }^{* * *}$ Significant $P$ value $(P<0.05)$ indicates a significant relationship between explanatory and response variables (e.g. \% FC)
} 


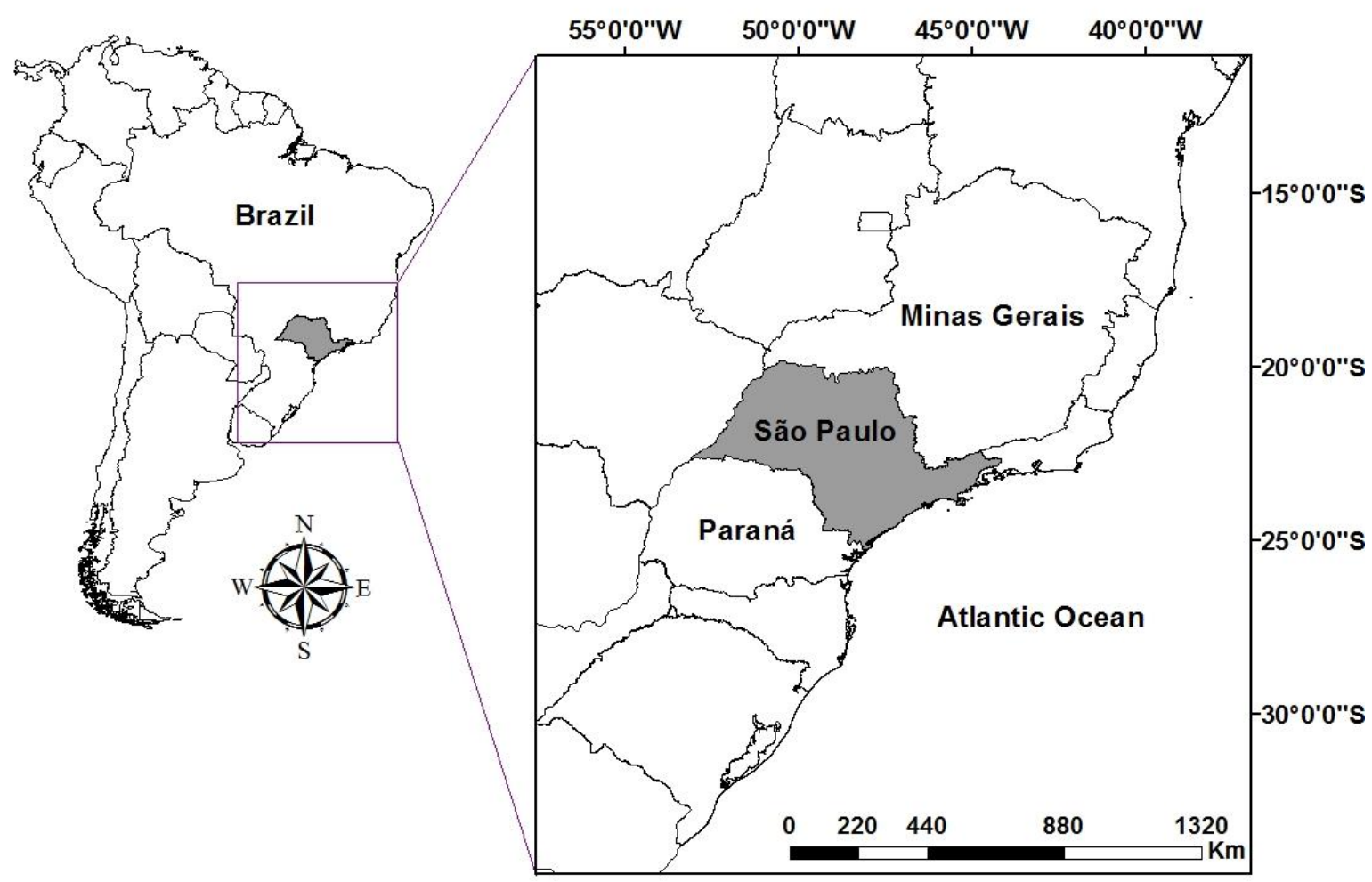

FIGURE 1. Location of the state of São Paulo, Brazil. 
A) IF - IBGE (ha)

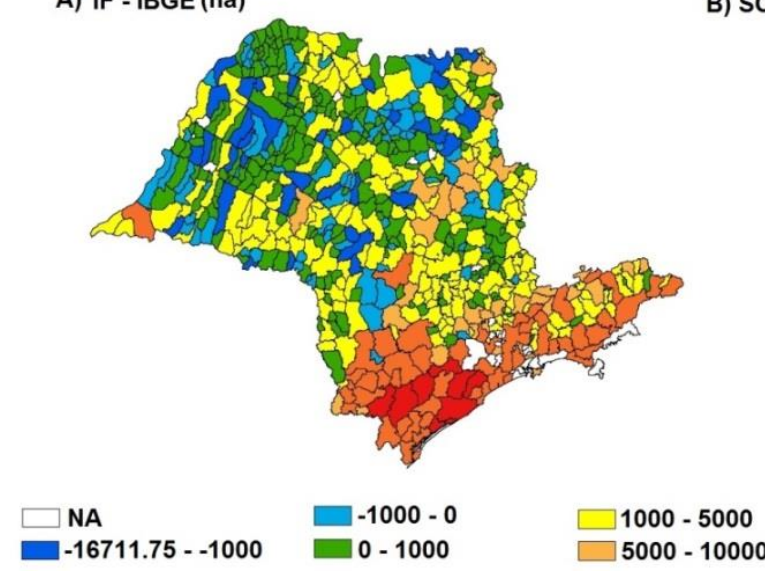

B) SOS - IBGE (ha)

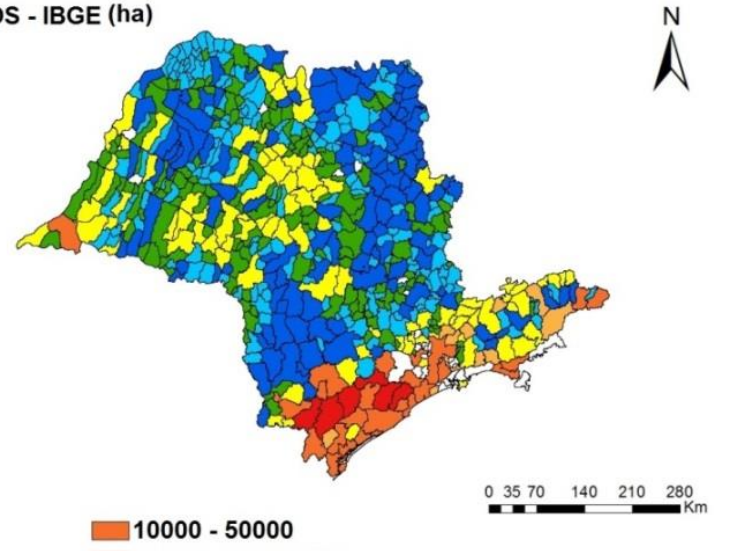

FIGURE 2. Differences between IF and IBGE (A), and SOS and IBGE (B) in hectares for all São Paulo's municipalities. Positive values indicate higher estimates from IF (A) and SOS (B) when compared to IBGE. 


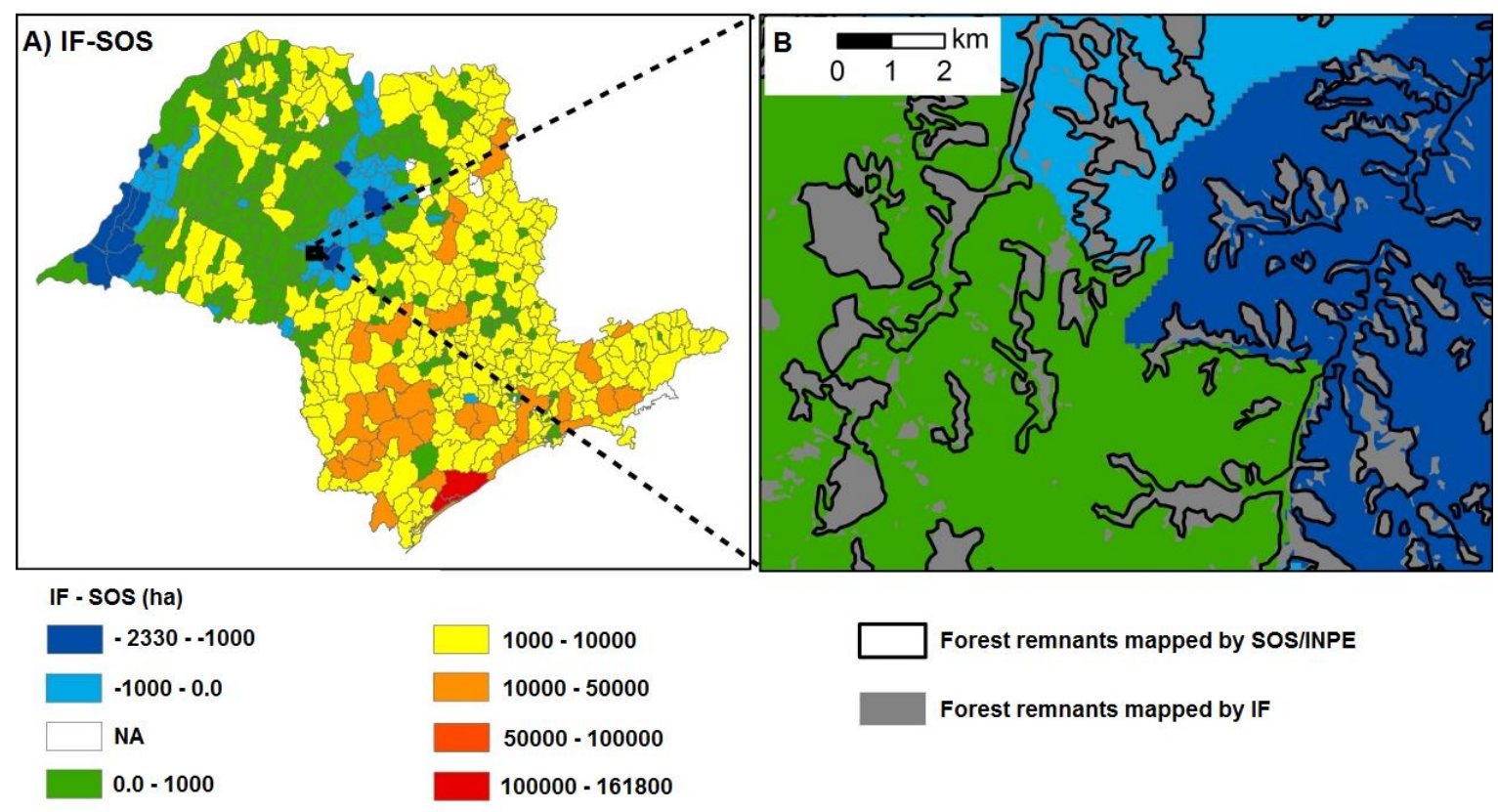

FIGURE 3. The difference between IF and SOS (A) in hectares for all São Paulo's municipalities. (B) Close-up of polygons delimited by SOS are shown in black contour and polygons delimited by IF in gray. 

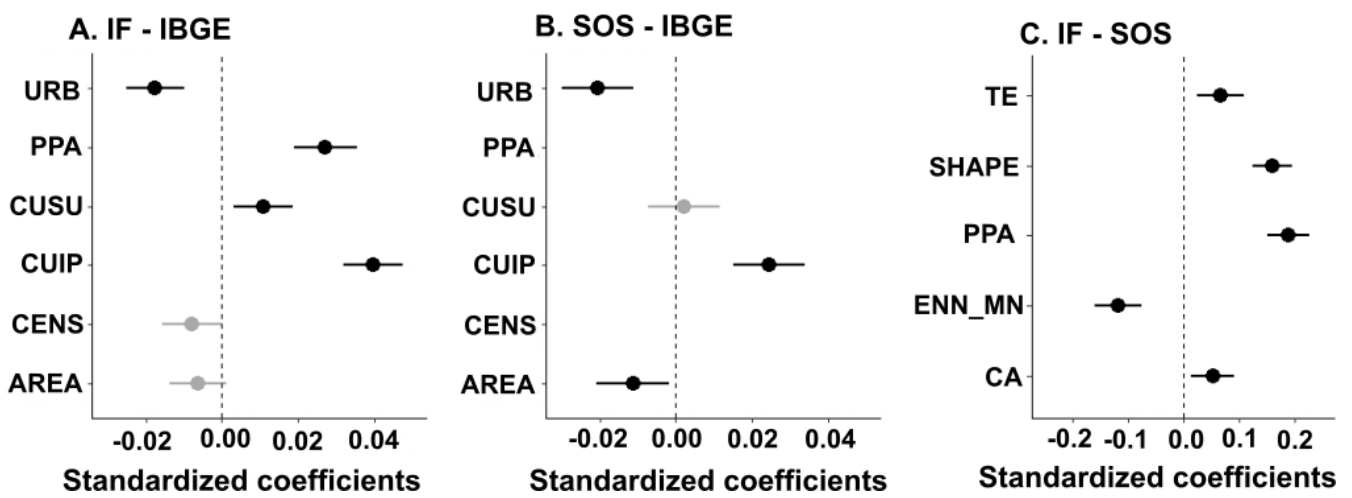

FIGURE 4. Results of models predicting the difference between forest cover estimates as a function of municipality features or landscape configuration. Parameter estimates of the best models (shown in Table 3) with mean (black dot) and confidence interval (2.5-97.5\%) for IF-IBGE (A), SOS-IBGE (B) and IF-SOS (C). Significance is based on values with $95 \%$ CI not overlapping zero. Non-significant coefficients are shown as grey symbols. Explanatory variables: $\mathrm{AREA}=$ municipality area (ha); PPA = Permanent Protection Areas $(\%)$; URB = urban area $(\%)$; CENS $=$ census area $(\%)$; CUIP $=$ Conservation Unit of Integral Protection (\%); CUSU $=$ Conservation Unit of Sustainable Use (\%); CA = total class area (ha); ENN_MN = Euclidean nearestneighbor distance; $\mathrm{SHAPE}=$ mean patch shape index; $\mathrm{TE}=$ total edge $(\mathrm{m})$. 
A. IBGE

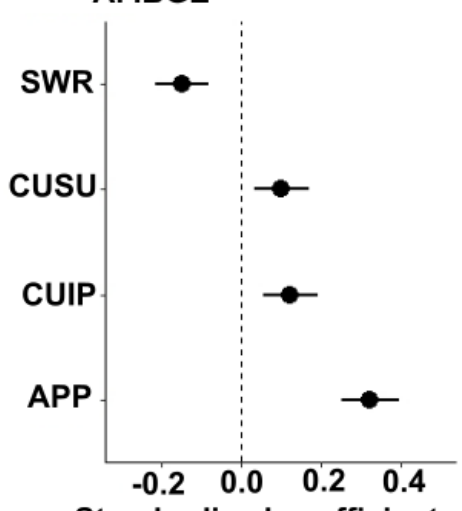

Standardized coefficients
B. IF

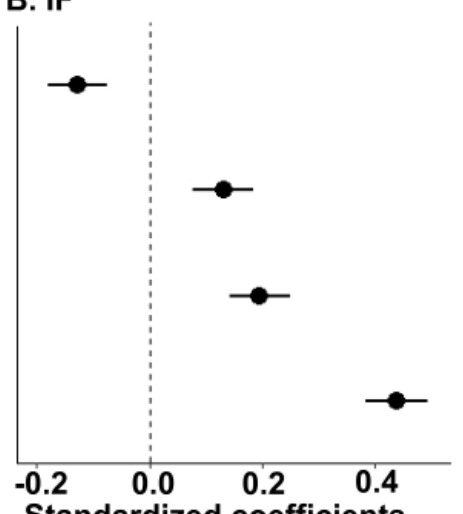

C. sos

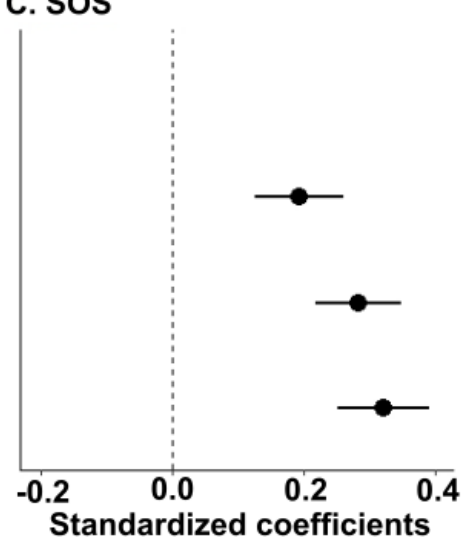

FIGURE 5. Results of models predicting forest cover as a function of protected areas and soil characteristic. Parameter estimates with mean (black dot) and confidence interval (2.5 - 97.5\%) for IBGE (A), IF (B) and SOS (C). The significance is based on values with $95 \%$ CI not overlapping zero. Explanatory variables: SWR $=$ Soil Water Retention Capacity; PPA = Permanent Protection Areas (\%); CUIP = Conservation Unit of Integral Protection (\%); CUSU = Conservation Unit of Sustainable Use (\%). 

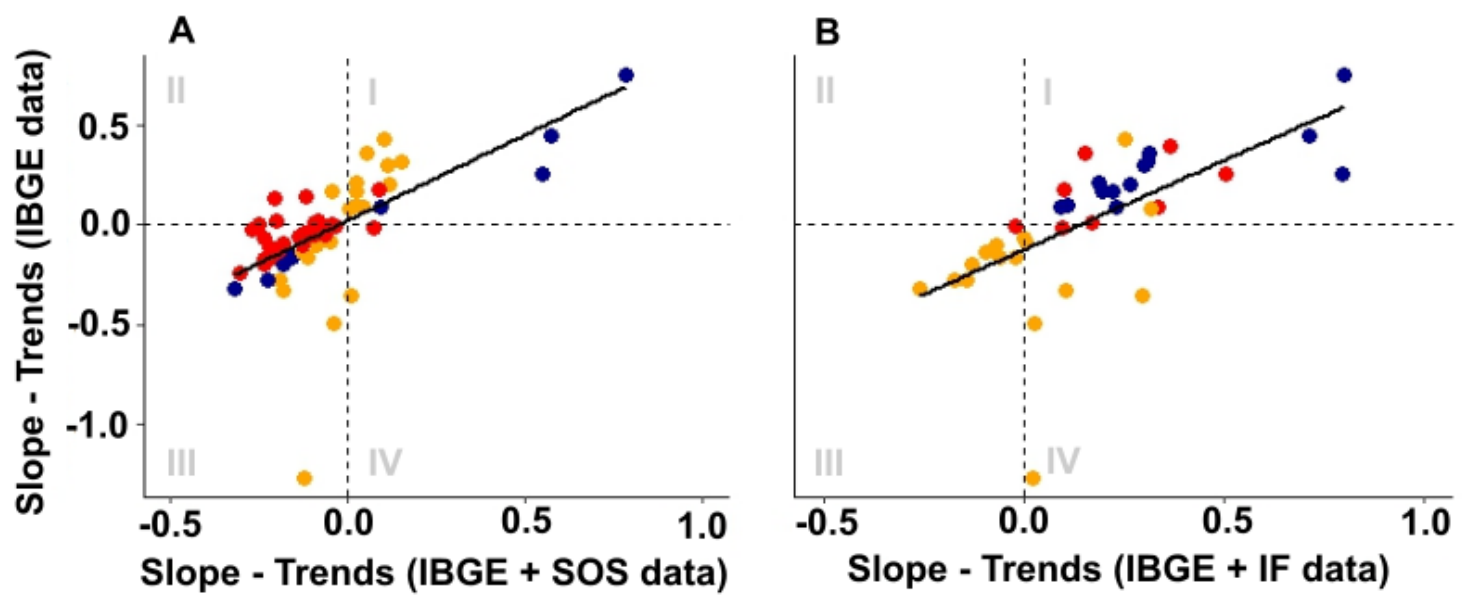

\section{$P$-value of the slopes}

- $P<0.05$ for IBGE and combined data

$P>0.05$ for IBGE, but $P<0.05$ for

$P<0.05$ for IBGE, but $P>0.05$ for combined data combined data

FIGURE 6. The relationship between regression slopes of forest cover trends calculated using only IBGE data and combining IBGE data with SOS data (A) or IF data (B). Equivalent trends appear in quadrants I and III, while contradictory trends appear in quadrants II and IV. 


\section{SUPPLEMENTARY MATERIAL}

TABLE S1. The configuration metrics used as the response variable (e.g. percentage of the landscape), and explanatory variables (e.g. total class area, total edge, Euclidean nearest-neighbor distance and mean patch shape index) and definition of each one.

\begin{tabular}{ll}
\hline \multicolumn{1}{c}{ Class metrics } & \multicolumn{1}{c}{ Definitions } \\
Percentage of landscape & $\begin{array}{l}\text { Percentage of the landscape that present forest cover } \\
\text { patches }\end{array}$ \\
\hline Total class area (ha) (CA) & $\begin{array}{l}\text { The sum of the total areas of all forest patches in the } \\
\text { municipalities }\end{array}$ \\
\hline Total edge (m) (TE) & $\begin{array}{l}\text { The sum of the edge lengths of all forest patches in } \\
\text { the municipalities }\end{array}$ \\
\hline $\begin{array}{l}\text { Mean Euclidean nearest- } \\
\text { neighbor distance (m) }\end{array}$ & $\begin{array}{l}\text { The mean of the shortest straight-line distances } \\
\text { between the forest patches and their nearest } \\
\text { neighboring forest patch. The index calculus was } \\
\text { made in municipality-scale }\end{array}$ \\
\hline $\begin{array}{l}\text { Mean patch shape index } \\
\text { (SHAPE) }\end{array}$ & $\begin{array}{l}\text { Shape index is calculated by dividing the patch } \\
\text { perimeter by the perimeter of a square patch. Mean } \\
\text { patch shape index is the mean of the shape index of } \\
\text { all patches in the municipalities. Higher shape index } \\
\text { values indicate a greater departure from a square } \\
\text { shape (i.e., the patch is more geometrically } \\
\text { complex). }\end{array}$ \\
\hline
\end{tabular}


TABLE S2. Explanatory variables used in the models for depicting IF's, SOS's and IBGE's estimates

\begin{tabular}{lcl}
\hline $\begin{array}{l}\text { Explanatory } \\
\text { variable }\end{array}$ & $\begin{array}{l}\text { Hypothesized } \\
\text { relationship }\end{array}$ & \multicolumn{1}{c}{ Rationale } \\
\hline $\begin{array}{l}\text { Percent of } \\
\text { Permanent }\end{array}$ & + & $\begin{array}{l}\text { Most of the forest patches out of conservation } \\
\text { units located in PPA, hence larger PPA in the } \\
\text { municipalities lead to higher percent of forest } \\
\text { cover in the municipalities }\end{array}$ \\
(PPA) & & $\begin{array}{l}\text { Forest cover patches tend to locate in less } \\
\text { suitable lands for agriculture (e.g. less humid } \\
\text { lands) }\end{array}$ \\
\hline $\begin{array}{l}\text { Soil water } \\
\text { retention } \\
\text { capacity (SWR) }\end{array}$ & - & $\begin{array}{l}\text { Larger forest patches located in conservation } \\
\text { units, hence larger CUSU lead to higher } \\
\text { percent of forest cover in municipalities }\end{array}$ \\
\hline $\begin{array}{l}\text { Conservation Unit } \\
\text { Sustainable Use }\end{array}$ & + & $\begin{array}{l}\text { Larger forest patches located in conservation } \\
\text { units, hence larger CUIP lead to higher } \\
\text { percent of forest cover estimated by IF and } \\
\text { Conservation Unit } \\
\text { of }\end{array}$ \\
$\begin{array}{l}\text { Integral Protection } \\
\text { (CUIP) }\end{array}$ & + & $\begin{array}{l}\text { SOS, but may not influence forest cover } \\
\text { estimated by IBGE since there are not rural } \\
\text { properties inside CUIP }\end{array}$ \\
& &
\end{tabular}



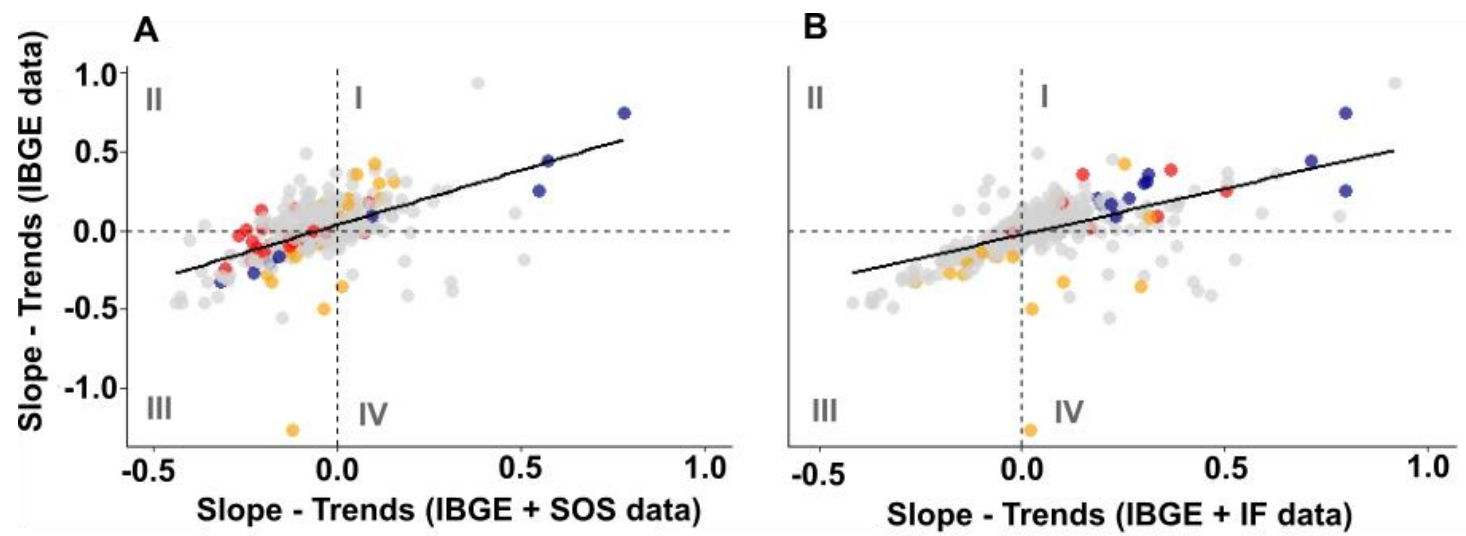

$P$-value of the slopes

$P>0.05$ for IBGE and combined data

$P>0.05$ for IBGE, but $P<0.05$ for combined data

$P<0.05$ for IBGE and combined data

$P<0.05$ for IBGE, but $\boldsymbol{P}>\mathbf{0 . 0 5}$ for combined data

FIGURE S1. The relationship between regression slopes of forest cover trends calculated using only IBGE data and combining IBGE data with SOS data (A) or IF data (B). Equivalent trends appear in quadrants I and III, while contradictory trends appear in quadrants II and IV. 


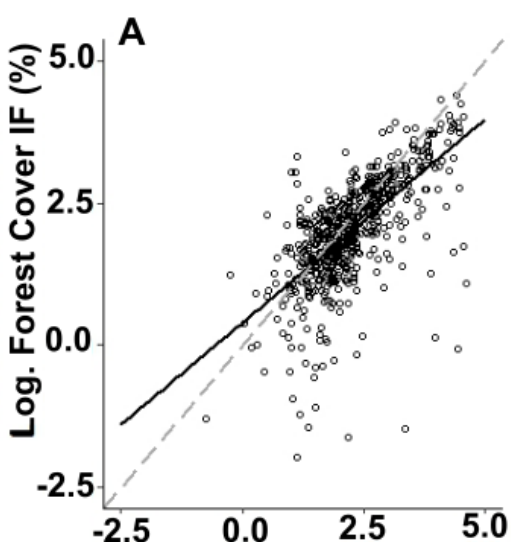

Log. Forest Cover IBGE (\%)

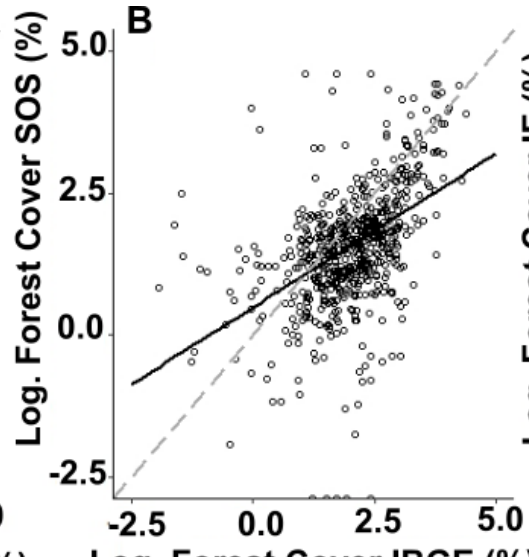

Log. Forest Cover IBGE (\%)

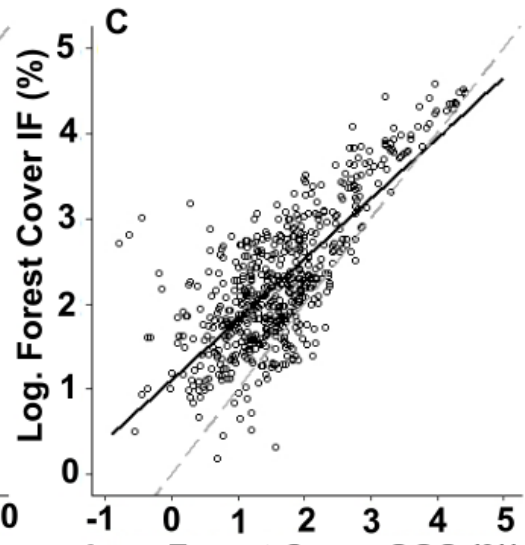

Log. Forest Cover SOS (\%)

FIGURE S2. Scatterplots of forest cover estimates in logarithm scale of IF and IBGE (A), SOS and IBGE (B), and IF and SOS (C) datasets. The regression line is in black. Dashed gray line illustrates the location of the dot in which forest cover estimates presented the identic values. 


\section{Capítulo 2}

THE FOREST TRANSITION IN SÃO PAULO, BRAZIL:

HISTORICAL PATTERNS AND PUTATIVE DRIVERS

Adriane Calaboni, Leandro R. Tambosi, Alexandre T. Igari, Juliana

Farinaci, Jean Paul Metzger, María Uriarte 
THE FOREST TRANSITION IN SÃO PAULO, BRAZIL: HISTORICAL PATTERNS AND PUTATIVE DRIVERS

Adriane Calaboni ${ }^{1}$, Leandro R. Tambosi ${ }^{1,2}$, Alexandre T. Igari ${ }^{3 \&}$, Juliana Farinaci ${ }^{4 \&}$, Jean Paul Metzger ${ }^{1}$, María Uriarte ${ }^{5}$

${ }^{1}$ Departamento de Ecologia, Instituto de Biociências, Universidade de São Paulo, SP, Brasil

${ }^{2}$ Centro de Engenharia, Modelagem e Ciências Sociais Aplicadas, Universidade Federal do ABC, Santo André, SP, Brasil

${ }^{3}$ Escola de Artes, Ciências e Humanidades, Universidade de São Paulo, SP, Brasil

${ }^{4}$ Centro de Ciência do Sistema Terrestre (CCST), Instituto Nacional de Pesquisas

Espaciais (INPE), São José dos Campos, SP, Brasil

${ }^{5}$ Department of Ecology, Evolution \& Environmental Biology, Columbia University, New York City, NY, United States of America

*Corresponding author

E-mail: bioadriane@gmail.com

${ }^{\&}$ These authors contributed equally to this work 


\begin{abstract}
Agricultural expansion has caused extensive deforestation throughout the tropics in the last decades, but nevertheless, some countries have experienced native forest gains. In the $20^{\text {th }}$ century, the state of São Paulo, Brazil, transitioned from an agricultural frontier to an agro-industrial state, and in parallel, from a high deforestation rate to native forest net gain. Here we examine the biophysical and socioeconomic factors which best explain land-use and forest cover change in São Paulo state, at the municipality scale, over four consecutive intervals between 1960 and 2006. We hypothesized that factors that increase the productivity of agricultural land or reduce pressure on land development would lead to reforestation. Although results differed among intervals, our results demonstrate that forest gains were greater in municipalities with high forest cover and steep slopes, and in areas that employed a large number of workers and relied on high fertilizer inputs. At the same time, forest loss was higher in moist soils and in municipalities with large tracts of agricultural land. These results demonstrate that land use expansion led to forest loss in areas more suitable for agriculture, while forest gains occurred mainly in less suitable areas. Over time, agricultural expansion leveled off and agriculture intensification enabled forest gains, which were most marked in areas with high forest remnants. Ultimately, however, these proximate drivers of forest change were driven by governmental policies to modernize agriculture and to protect natural ecosystems.
\end{abstract}

Key-words: forest transition; forest cover change; land-use change; São Paulo. 


\section{INTRODUCTION}

Agricultural expansion throughout the tropics in the 1980's and 1990's occurred mainly at the expense of forests (Gibbs et al. 2010). Currently, large-scale commercial agriculture is the most important driver of deforestation in the tropics (DeFries et al. 2010, Hosonuma et al. 2012, Rudel 2015). The magnitude and pervasiveness of tropical deforestation over the past three decades has led to food insecurity, high pest pressure, biodiversity loss, reduced availability of clean water, depleted soils, and increased vulnerability to climate extremes (Foley et al. 2005). At the same time, however, some developing countries, including Brazil, have lessened the pressure of agriculture expansion on forests (Lapola et al. 2014). Understanding the patterns of forest change and the underlying causes is a key to governmental policies development that ensures biodiversity preservation, climate regulation, and the support of human populations.

Multiple drivers that act synergistically lead to tropical deforestation by influencing land use directly (proximate causes) and indirectly (underlying driving forces) (Geist \& Lambin 2002). Human activities, including expansion of agricultural lands, wood extraction, infrastructure development, and changes in disturbance regimes are the proximate causes of forest loss and degradation (Geist \& Lambin 2002). Ultimately, however, human decisions are driven by underlying forces such as growth in local and international markets for agricultural and timber products, technological advances, agriculture development policies, industrialization, and urbanization (Geist \& Lambin 2002). For example, deforestation at the global scale has been related to agricultural expansion to supply the growing urban populations through expanding local and global markets (DeFries et al. 2010).

Despite forest losses in many areas of the tropics, a growing number of studies document cases of large-scale forest reforestation (Rietbergen-McCracken et al. 2007, Brancalion et al. 2016, Chazdon \& Guariguata 2016). Tropical countries like Costa Rica, Puerto Rico, Nicaragua, South Korea, Vietnam, and Guatemala, among others, have experienced forest cover net gain in the last decades (Aide et al. 2013, Redo et al. 2012, Yackulic et al. 2011, Crk et al. 2009). This shift from deforestation to reforestation is explained by Forest Transition Theory, the idea that as a nation develops economically its forest cover declines, but as far as development become less dependent of primary sector (e.g. timber extraction, agriculture and cattle 
ranching) deforestation tends to halt or even reverse. The transition occurs when reforestation rate exceeds the deforestation rate, leading to net forest gain (Mather \& Needle 1998, Rudel et al. 2005).

Particular chains of events, which vary spatially and temporally, can lead to a shift from deforestation to reforestation. The marked decline of ecosystem services and goods provided by native forests, for example, encourage economic incentive schemes that can induce landowners to slow down or halt agriculture expansion (Lambin \& Meyfroidt 2010). Law enforcement also contributes to the protection of important or irreplaceable natural areas (Meyfroidt et al. 2014). On the other hand, agricultural modernization driven by the widespread use of fertilizers, pesticides and machinery increases land and labor productivity and make economically feasible a retraction on cultivated area and abandonment of marginal lands (Mather \& Needle 1998, Barretto et al. 2013). These same factors, however, can lead to deforestation in agricultural frontiers where land is not scarce and the marginal benefits of intensification are less important (Barretto et al. 2013, Meyfroidt et al. 2014).

Biophysical factors are also important determinants of land-use change, influencing both forest cover loss and gain. Reforestation is more likely to occur in areas which face low opportunity costs from agriculture or other extractive land uses. For example, the probability of reforestation is higher on lands distant from dense urban areas and roads, on steep slopes, rocky terrain, and in low fertility soils (Silva et al. 2007, Yackulic et al. 2011). Since the majority of tropical forest trees are dispersed by animals, forest remnants are also critical determinants of regeneration potential as they provide habitat for pollinators and seed dispersers (Thomlinson et al. 1996, Holl 1999). Conversely, deforestation is more likely near roads, human settlements, and fertile lands (Freitas et al. 2010, 2013).

Despite these general patterns, large-scale natural reforestation or deforestation is largely determined by cultural, institutional, or economic contexts (Perz 2007, Chazdon \& Guariguata 2016). As a result, different countries/regions exhibit distinct and complex deforestation and reforestation trajectories which are contingent on their prior socioeconomic, political and development histories (Meyfroidt \& Lambin 2011, Redo et al. 2012). Hence, trajectories of forest cover change in any given country or region, and the factors that enabled them, cannot describe or predict the trajectory in others (Redo et al. 2012). 
In the $20^{\text {th }}$ century, the state of São Paulo, Brazil, transitioned from an agricultural frontier to an agro-industrial state, and in parallel, from a high deforestation rate to native forest net gain. Therefore, this study aimed to deepen our understanding of the factors related to forest transition in the state São Paulo, Brazil. To do so, we assessed historical patterns of forest cover change in the state between 1960 and 2006 together with the socioeconomic and biophysical factors associated with forest cover loss and gain. We examine both losses and gains because net change in forest cover does not provide insight into the specific drivers of deforestation and reforestation (Perz 2007). Because the drivers of forest cover change shift over time (Silva et al. 2016), we investigate the change over four consecutive periods: 1960-1970, 1970-1980, 1980-1996 and 1996-2006. Socioeconomic and biophysical factors for analyses were chosen based on studies in São Paulo (Silva et al. 2016) and elsewhere in the tropics (Crk et al. 2009, Yackulic et al. 2011) and were informed by knowledge of São Paulo land-use history. We ask:

(1) What are the patterns of deforestation and reforestatino across the state over the four consecutive periods?

(2) What factors drive forest gains and losses? We hypothesize that factors that increase the productivity of agricultural land or reduce pressure on land development will lead to reforestation. Hypotheses associated with each factor are provided in Table 1.

\section{METHODS}

STUDY SITE. - The state of São Paulo covers 24.6 million hectares (3\% of Brazilian territory) (Fig. 1) and comprises 645 municipalities with a total population of 41.3 million people (21.6\% of the country's population, IBGE 2011). During the $20^{\text {th }}$ century, the state shifted from an agricultural frontier to an agro-industrial developed state; and from a high deforestation rate to a native forest net gain at the end of the $20^{\text {th }}$ century. Important socioeconomic changes occurred in São Paulo during this period, including expansion of export crops, mechanization of agriculture, and significant increases in fertilizer and pesticide use (Veiga \& Otani 1983, Camargo \& Santos 1985, Garcia 1986, Carvalho \& Silva 1987, Chabaribery 1999). These changes led to high rates of rural-urban migration (Garcia 1986, Ghilard 1986). Currently, $96 \%$ of the 41.3 million inhabitants of São Paulo live in the urban centers (IBGE 2011). 
As a consequence of centuries of intense occupation and agricultural growth, the Atlantic Forest in São Paulo retains only $16.2 \%$ of its original cover (SOS/INPE 2015). Most remnant forest patches are scattered and fragmented (Ribeiro et al. 2009). Nevertheless, recent assessments indicate a marked reduction in deforestation since 1985 (Lira et al. 2012, SOS/INPE 2015) and a net increase of native forest cover at the state scale (Farinaci \& Batistella 2012). Studies at landscape scale have related forest gain in São Paulo to increasing distance from roads and major cities and steeper slopes (Teixeira et al. 2009, Freitas et al. 2010, Freitas et al. 2013).

Studies at state scale use aggregate data that mask important variation in finer scales, as municipality scale. Analyses at municipality scale are necessary if we are to understand the socioeconomic factors that underlie long-term forest cover change in São Paulo.

DATA. - Forest cover and socioeconomic data were obtained from the Brazilian National Agrarian Census Surveys (IBGE - Brazilian Institute of Geography and Statistics) for the years 1960, 1970, 1980, 1996 and 2006. IBGE data are available at SIDRA database (http://www2.sidra.ibge.gov.br/).

The Agrarian Census Survey is conducted only in private properties with some agriculture activity (e.g. agriculture, forestry or aquaculture) in rural and urban areas; excluding Conservation Units. Surveys include personal interviews with landowners and managers. Percentage of forest cover was calculated by dividing the total forest cover area (ha) of each municipality by the total census area (e.g. municipality area in which the census was taken). IBGE considers as "forest" old-growth forests, woodlands, shrubs and also secondary forests at the initial stage of succession.

Socioeconomic variables include density of permanent farm workers, the number of tractors per area, and the percentage of farms that used fertilizer. The density of farm workers was calculated by dividing the number of permanent workers on farms by the total census area in the municipality. We also included the percentage of pasture, exotic tree plantations, annual and perennial crops, and uncultivated land. Uncultivated lands are those which have not been planted for more than four years at the time of the census. They included lands exhausted by erosion, salinization and desertification. Biophysical variables included average slope, soil water retention capacity, and forest cover percentage at the start of the interval. The forest cover 
percentage at the start of the interval was included to assess the effect of previous forest cover extension on deforestation or reforestation. Supplementary Information (Fig. S1-S10) provides geographic distributions and temporal changes for all factors included in the analyses.

StATISTICAL ANALYSES. - Forest cover at the end of the interval was used as the response variable. We fitted linear mixed-effect models to associate forest cover change to 11 socioeconomic and biophysical factors (Table 1). Forest cover at the end of the interval was log-transformed in order to meet assumptions of normality. We used the ratio of the explanatory variables at the start and end of the census to assess if changes in socioeconomic factors are associated with changes in forest cover between periods. We calculated this ratio by dividing the values in one census by values in the previous census (e.g. pasture in 1970 / pasture in 1960, where values $>1$ indicate that pasture area increased and values $<1$ indicate that pasture area decreased). We use the percentage of establishments that used fertilizer, instead of ratio, because the data was not available for 2006. All fixed explanatory variables were standardized by subtracting the mean and dividing by one standard deviation (Gelman \& Hill 2007). To avoid collinearity, we excluded all variables with pairwise Pearson's correlation coefficients $r \geq 0.4$.

As the socioeconomic development of a municipality may be associated with the development of its neighboring municipalities, thereby introducing spatial autocorrelation in the response variable, we used as random effect the São Paulo's micro-regions. The micro-regions are sets of neighboring municipalities grouped by IBGE according to socioeconomic similarities.

Model selection was conducted separately for each period (1960-1970, 19701980, 1980-1996 and 1996-2006). Starting with the full model (i.e., all variables in Table 1), we compared all sub-models by dropping each of the explanatory variables. For this analysis, we used the function dropl from the package stats (R Development Core Team 2016a). We used Akaike's Information Criterion (AIC) to select the best model for each period (Burnham \& Anderson 2002). This approach allowed us to select a unique set of variables for each period, which we used to test all the possible combination of explanatory variables for each period. For this analysis, we used the function dredge from the package MuMIn (Barton 2016). Models were validated by 
plotting residuals against fitted values to assess homogeneity and by testing for normality. All analyses were conducted using R statistical software (R Development Core Team 2016b).

\section{RESULTS}

PATTERNS OF CHANGE IN FOREST COVER. - Between 1960 and 2006, there was a net gain in forest cover in the state of São Paulo. The number of municipalities showing forest reforestation increased steadily over the same period (Fig. 2). In parallel, there was a significant temporal and spatial variation in forest cover and dynamics among municipalities. In 1960-1970, forest cover declined in most municipalities (Fig. 2), and it was particularly marked in the western part of the state. In 1970-1980, deforestation was concentrated in the Center and North of the State and the number of municipalities which showed reforestation increased during that period.

Since 1980, the majority of the municipalities in São Paulo gained forest (Fig. 2), leading to a net gain in forest cover at the state scale (Fig. 3A). Despite these gains in forest cover, the large majority of São Paulo's municipalities had a low percentage $(<30 \%)$ of forest cover throughout the period (Fig. S1).

SPATIO-TEMPORAL VARIATION IN DRIVERS OF FOREST CHANGE. - Spatial and temporal variation in putative drivers of deforestation and reforestation were largely consistent with our hypothesis (Table 1), illustrating the effects of agricultural expansion and modernization across the state. The number of tractors per area (Fig. S2) and the percentage of farms which used fertilizer (Fig. S3) increased steadily throughout the state between 1960 and 2006 (Fig. 3B). At the same time, the density of workers on farms decreased in most of the municipalities over the study period (Fig. 3C \& Fig. S4).

At the state scale, in 1996-2006 shifts in land use/cover were slight (Fig.3), but at the municipality-scale land use varied significantly over the study period (Fig. S5S9). The extent of pasturelands at the state scale was stable over the study period (Fig. 3D). At municipality scale, however, gains in pasturelands occurred mainly in the West region, while simultaneously declining in a large portion of municipalities over the study period (Fig. S5). Perennial and annual crops also increased slightly at state scale (Fig. 3D). At municipality scale, perennial crops (Fig. S6) increased in 
most municipalities in 1970-1980 and 1996-2006, while annual crops (Fig. S7) expanded throughout the entire state in1996-2006. The extent of exotic tree plantations was quite stable between 1960-2006 at the state scale (Fig. 3E), but slightly decreased in several municipalities (Fig. S8). Uncultivated lands decreased slightly at state scale (Fig. 3E), reflecting increases in many municipalities over the study period (Fig. S9).

These aggregate patterns obscured variation in land use change between decades and across municipalities, hindering our ability to identify patterns of landuse substitution over time in the state. For example, pasture increased in municipalities in the North and West regions (Fig. S5) and uncultivated areas decreased in most municipalities in 1970-1980, but increased in 1996- 2006, primarily in the Western part of the state (Fig. 3E \& Fig. S6). Our data do not allow us to determine if extensive pasture expanded over uncultivated lands in the N.W. regions of São Paulo in 1970-1980 or if pasture abandonment in 1996-2006 led to the increase of uncultivated lands. Nevertheless, we can examine the degree to which shifts in forest cover in municipalities and across census periods were associated with shifts in potential drivers.

\section{WHAT FACTORS DRIVE FOREST GAINS AND LOSSES OVER THE STUDY PERIOD?}

BIOPHYSICAL FACTORS. - Forest cover percentage at the start of the interval was positively associated with forest cover at the end of the interval all census periods (Figures 4A-D) indicating that higher forest cover -albeit lower than 30\% in most municipalities - facilitated reforestation (Fig. S1). In accordance with our expectations, forest reforestation consistently occurred in municipalities with steep slopes across the study period (Figs. 4A-D).

As we hypothesized, areas with high soil water retention capacity had high rates of forest cover loss between 1960 and 1996 (Figs. 4A-C). However, this was not the case in 1996-2006 (Fig. 4D) (Table 2).

Most municipalities in São Paulo have soils with higher water retention capacity, flat slopes (Fig. S10) and low forest cover (Fig. S1). Municipalities with low soil water retention capacity, steep slopes and high forest cover in those years are concentrated in the coastal region, and in a narrow band that extends from southwestern to north-eastern São Paulo. Changes in forest cover across that band of 
municipalities indicate that until 1980 agriculture expanded also over less suitable lands, but since 1980 such lands have been gradually abandoned (Fig. S1 \& S10).

EFFECTS OF LAND COVER CHANGE. - We expected that the expansion of low productivity pasture and annual crops would be associated with forest loss (Table 1). However, increases in the extent of pasture (i.e., high pasture ratios) were associated with forest loss in 1960-1970 and 1980-1996 (Fig. 4A \& 4C), gains in forest cover in 1970-1980 (Fig. 4B); and did not have an effect on forest cover change in 1996-2006 (Table 2 \& Fig. 4D). As expected, expansion of annual crops (i.e. high annual crop ratios) was associated with forest cover loss but only in 1960-1970 (Fig. 4A).

We had also hypothesized that gains in forest cover would be associated with increases of uncultivated, perennial crops or exotic tree plantations, but this was not the case. Expansion of perennial crops (e.g. high perennial crop ratios) was associated with declines in forest cover in 1960-1970 and 1980-1996 (Table 2 \& Fig.4A \& 4C), but it was not an important factor for explaining forest cover change in 1970-1980 or 1996-2006 (Table 2 \& Figs. 4B \& 4D). Expansion of exotic tree plantation was positively associated with forest gains in 1996-2006 but negatively associated with forest cover in 1980-1996, contradicting our expectations (Figs. 4C \& 4D). As expected, increases of uncultivated land were associated with forest gains but only in 1996-2006 (Fig. 4D), showing that lands previously exhausted by agriculture tended to be abandoned during that decade. This pattern, however, was not evident during earlier periods (Table 2).

FARM PRODUCTIVITY. - We hypothesized that increases in farm productivity, as reflected in larger use of tractors or fertilizers, and a decline in the number of rural workers might lead to increases in forest cover (Table 1). As expected, increases in the percentage of farms that used fertilizer were associated with forest cover gains in 1996-2006 (Fig. 4D) but this was not the case for any other period (Table 2). In 19701980, increases in the density of farm workers were associated with forest cover gains (Fig. 4D), suggesting that increasing the number of employees led to reforestation and not the reverse as we hypothesized. However, changes in the density of farm workers did not influence forest cover change in any other period (Table 2). Changes in tractor use were not a significant predictor of forest cover change in any period. 


\section{DISCUSSION}

CHANGE IN FOREST COVER AND PUTATIVE DRIVERS. - São Paulo exhibited marked changes in forest cover between 1960 and 2006, with forest loss occurring between 1960 and 1980 and the transition to reforestation from 1980 onwards. These transitions were particularly marked in agricultural areas suggesting that shifts in modes of agricultural production in the state, from family-based agriculture to industrial agriculture are the underlying causes of forest cover change in the past few decades.

Agriculture was extremely dynamic in São Paulo during the $20^{\text {th }}$ century. Agricultural frontier expansion to North and Western São Paulo was facilitated by a marked increase in coffee production and export in the early $20^{\text {th }}$ century that encouraged the construction of railroads (Chabaribery 1999). After the coffee crisis in 1930, large coffee growing regions in the North and West of the state were replaced by cotton farms which in turn declined significantly between 1940 and 1989 (Chabaribery 1999). Over the same time, extensive cattle ranching became the main activity in those regions (Bini 2009). In 1970's citrus expanded significantly from municipalities in the East to the North, forming the "citrus belt" of São Paulo, where important industries of juice concentrate established (Chabaribery 1999). The PROÁLCOOL program created in 1973, encouraged expansion of sugarcane production from Center and Eastern São Paulo to almost all the regions in the state, first displacing mainly staple crops (e.g., beans, manioc) and then pasturelands (Chabaribery 1999).

The shift to reforestation was likely facilitated by changes in agricultural policy. In 1965, the Brazilian government created the Rural Credit Subsidy System (RCSS) that encouraged farmers to purchase agricultural machinery, fertilizer, and pesticides (Baer 2008) which particularly benefited production of export crops (e.g. soybean, orange, coffee, sugarcane) (Veiga \& Otani 1983, Garcia 1986, Martins 1986, Ghilard 1986). With the establishment of RCSS in 1965, the number of tractors per area and the percentage of establishments that used fertilizer increased significantly, promoting agriculture intensification. In the long term, however, high-tech agricultural inputs led to the abandonment of marginally productive lands and encouraged rural- 
urban migration in the state (Veiga \& Otani 1983), promoting a significant decrease in the density of permanent workers in rural areas.

\section{WHAT FACTORS DRIVE FOREST GAINS AND LOSSES OVER THE STUDY PERIOD?}

Our results show that the trajectory of forest cover change in São Paulo between 1960 and 2006 is related to agriculture transformation in that period.

EFFECTS OF BIOPHYSICAL FACTORS. - Biophysical features of the municipalities were important determinants of forest cover change. Between 1960 and 2006, reforestation was concentrated in lands with low suitability for agriculture, consistent with studies elsewhere (Crk et al. 2009, Yackulic et al. 2011) and in São Paulo (Silva et al. 2007, Teixeira et al. 2009). Agricultural expansion and intensification probably made nonproductive lands less attractive for agriculture leading to reforestation, mainly after 1980. Soil water retention capacity, an important indicator of agricultural suitability, was associated with forest loss between 1960 and 1996 but it had no effect between 1996 and 2006. This pattern is probably related to the establishment of RCSS, enacted in 1965, which encouraged the use of high-tech inputs to increase productivity (e.g. pesticides, fertilizers and irrigation systems) (Ghilard 1986). Compliance with the environmental law could possibly account for the lack of association between soil moisture and forest change between 1996 and 2006. The creation of the National Council of Environment (CONAMA) and Brazilian Institute of Environment and Natural Resources (IBAMA) by Brazilian Government, and São Paulo State Council of Environment (CONSEMA) by São Paulo's Government during the 1980's probably played a key role on sparing fragile areas (e.g. steep slopes) which regenerated 1980 onwards.

Our results also indicate that the extent of forest cover facilitated forest gains in São Paulo, probably because municipaltiy socioeconomic contexts encouraged forest recovery, as also observed by other studies (Crk et al. 2009, Silva et al. 2016). Additionally, forest remnants are important seed sources after land use and abandonment (Baider et al. 2001) and shelter important seed dispersers (Holl 1999, Babweteera \& Brown 2009, Hooper et al. 2004), facilitating forest regeneration. However, forests increase in São Paulo has happened in parallel to old-growth forest decrease (Lira et al. 2012, Ferraz et al. 2014), possibly contributing to the 
impoverishment of the forests in the state and a decline in the provision of ecosystem services (Ferraz et al. 2014).

EFFECTS OF LAND-USE CHANGE. - Forest loss associated with pasture expansion in 1960-1970 is possibly related to the substitution of coffee and cotton by pasture in north and west of São Paulo. Extensive cattle ranching was a cheap alternative to overcome coffee and cotton crisis in the region (Bini 2009). In 1970-1980, pasture expanded mainly into Western São Paulo where land prices were low (Bini 2009). In 1980-1996, pasture expansion caused deforestation mainly in North and Western São Paulo, as a consequence of pasture displacement on other regions by more lucrative crops, as sugarcane, orange and exotic tree plantation (Sparovek et al. 2007). On the other hand, forest gains may result in abandonment of highly exhausted pasture area. This cycle of driven land-use change causes forest gains in one region at the expense of agricultural expansion in more profitable agricultural lands (Pfaff \& Walker 2010).

Low-profit extensive pasture requires a minimal infrastructure (e.g. paved roads, machines, specialized labor, and electricity), but demands large areas (Sparovek et al. 2007). On the other hand, sugarcane mills and fruit processing industries demand machinery, dense paved road network, services, and labor, and benefit from proximity to research centers and farms (Maia 1996, Sparovek et al. 2007). As a result, the infrastructure development inflates land prices and sugarcane and orange farms become predominant, encouraging the displacement of less profitable activities, mainly extensive cattle ranching, to regions where lands are cheaper (e.g., leakage) (Egeskog et al. 2016). A similar pattern to what we found in São Paulo municipalities was observed at the sub-national scale in Brazil. Atlantic Forest recovery has been facilitated in part by the expansion of the agriculture in Amazonian biome (Walker 2012, Barretto et al. 2013). The sugarcane expansion to western São Paulo has likely led local cattle ranchers to lease or sell their lands and buy cheaper lands in the North and Central-West regions of Brazil (Sparovek et al. 2007, Barretto et al. 2013).

Increases in annual crops were associated with deforestation only in 19601970. High sugar prices during that decade encouraged sugarcane expansion in the state (Silva 1983), while research and innovation facilitate soybean expansion in the Cerrado of São Paulo (Camargo \& Santos 1985). As a result, sugarcane and soybean production for export increased substantially in São Paulo during that decade 
(Carvalho \& Silva 1987), potentially leading to deforestation. The substitution of family based-agriculture by export crops was common in São Paulo from 1960 onwards (Caser et al. 1994, Chabaribery 1999). Small farms merged into larger farms for mechanized large-scale production and export (Olivette \& Camargo 2009) and forests, often maintained by smallholders, as woodlots and hedgerows (Lambin \& Meyfroidt 2010, Meyfroidt \& Lambin 2011) were cleared.

Expansion of perennial crops in 1960-1970 and 1980-1996, but not during other decades, was associated with forest loss. This variability across decades may reflect the effects of citrus expansion during 1960's and 1980's, a very important perennial crop in São Paulo. In the 1960s, São Paulo shifted from exporting raw oranges to concentrated juice, what promoted crop expansion (Maia 1996). By the 1980's, the state became the main producer and exporter of concentrated juice in the world, encouraging further expansion of citrus cultivation (Maia 1996, Amaro 1996).

The expansion of exotic tree plantation was associated with forest loss in 1980-1996 possibly because Brazilian Government granted economic incentives to forestry industries and landowners between 1966 and 1987 (Viana 2004). On the other hand, expansion of exotic tree plantation was associated with forest gains in 19962006. The optimization of the productive chain of pulp and paper and the demand for environmental certification, which entails adapting to international standards and law compliance, possibly promoted land abandonment to increase native forest cover (Farinaci et al. 2013, Silva et al. 2016). For example, in 2000-2007 landowners of some municipalities established plantations while allowing regeneration in pasture and riparian areas (Farinaci 2012). Such abandonment was motivated mainly by conservation concerns and aesthetic value of natural areas for the properties (Farinaci 2012).

As we expected, increases in uncultivated lands were related to forest gains but only in 1996-2006. Undoubtedly, this forest gain is related in part to agriculture modernization in São Paulo; but also to the fact that agro-industry and landowners must comply with BFC (enacted in the 60's) and state environmental regulations (created in the 80's) in order to obtain environmental certification and reach foreign markets. The fact that forest cover increase was prominent only after 1996 also suggests that the legal incoherence between RCS and BFC may have hindered reforestation in earlier decades (Igari et al. 2009, Igari \& Pivello 2012). However, 
international market pressures for environmental certification were essential to promote abandonment of marginal lands (e.g. instance degraded pasture), allowing reforestation in São Paulo.

EFFECTS OF FARM PRODUCTIVITY. - Gains in farm productivity, measured by increased fertilizer use and the number of permanent workers on farms, were associated with forest gain in some periods but these factors were not as important as biophysical factors and changes in land-use. Higher productivity resulting from increased fertilizer use in agriculture between 1996 and 2006 may have enabled the abandonment of marginal lands. Expansion of large-scale sugarcane production, a crop that uses high amounts of pesticides and chemical fertilizers (Sparovek et al. 2007), increased significantly in most of the municipalities in 1996-2006 (Olivette \& Camargo 2009).

The decrease of permanent workers on farms has been associated with forest gains since out-migration encourage agriculture modernization and productivity increase (Lambin \& Meyfroidt 2010). However, the increase of permanent workers led to forest gains in São Paulo in 1970-1980. Expansion of highly mechanized crops (sugarcane and soybean) led to the decline of permanent workers, mainly families, in São Paulo in 1970-1980, but in municipalities that maintained a diversified agriculture for local market the number of permanent workers was largely constant in 1970's (Garcia 1986). Hence, apparently, landowners practicing diversified family-based agriculture maintained forest cover and allowed forest regeneration in their properties in 1970-1980.

\section{CONCLUSION}

The biophysical and socioeconomic factors that drove forest cover change differed among municipalities but their effects varied temporally, showing that human pressure on land shifts in response to economic changes and political measures (Silva et al. 2016). Agricultural expansion led to deforestation on most suitable agricultural lands, but then a number of factors that increase productivity or reduced pressure on land development led to reforestation. Ultimately, however, these proximate factors were driven by governmental policies to modernize agriculture (e.g. PROÁLCOOL and RCS), to protect natural ecosystems (e.g. BFC, CONSEMA, CONAMA, and IBAMA) and by international market demands for environmental certification. 
Like many developing countries, Brazil has invested resources and human capital towards export crop commodities, since these investments can lead to economic development. These policies and investments have led to a transition from family/extensive to industry/intensive agriculture during a short period of time (Lapola et al. 2014). São Paulo is an example of the advanced stages of agriculture consolidation and intensification processes. Changes in forest cover have declined over the past few decades, reflecting land use adjustments, as a result of enforcement of environmental regulations and shifts in commodity prices. At present time, agriculture development in the state is not necessarily linked to deforestation. However, up-to-date, economic development promoted by agro-industry in São Paulo has been decoupled from an overall social and health development, a common pattern in tropical developing countries.

\section{ACKNOWLEDGMENTS}

Adriane Calaboni was funded by the Brazilian Ministry of Education (CAPES) doctoral studentship. We would like to thank Dr. Jefferson Mariano (IBGE/SP) and Antônio Carlos Simões Florido (IBGE/RJ) for gently helping authors with SIDRA database and Brazilian National Agrarian Census Survey data. We also thank MSc. Julia Barreto, Dr. Mariana Morais Vidal, Dr. Paula Ribeiro Prist, Dr. Cristina BanksLeite and Dr. Elizabeth Nichols for the insights that greatly improved the manuscript.

Data Availability: The data used in this study are archived at Sistema IBGE de Recuperação Automática - SIDRA (http://www2.sidra.ibge.gov.br/bda/agric/default.asp?z=t\&o=11\&i=P).

\section{LITERATURE CITED}

Aide, T.M., M.L. Clark, H.R. Grau, D. Lópes-CarR, M.A. LeVy, D. RedO, M. Bonilla-Moheno, G. Riner, M.J. ANDRAdE-NúÑEZ, M. MuÑIZ. 2013. Deforestation and Reforestation of Latin America and the Caribbean (20012010). Biotropica 45: 262-271.

AmARO, A. A. 1996. Situação e perspectivas da citricultura. Informações Econômicas 26: 23-26.

BABWETEERA, F., and N. BROWN. 2009. Can remnant frugivore species effectively 
disperse tree seeds in secondary tropical rain forests? Biodivers. Conserv.18: 1611-1627.

BAER, W. 2008. The Brazilian growth and development Sixth Edit. Lynne Rienner Publishers, Boulder, CO.

Baider, C., M. TABarelli, and W. Mantovani. 2001. The soil seed bank during Atlantic forest regeneration in Southeast Brazil. Braz. J. Biol. 61: 35-44.

Barretto, A. G. O. P., G. Berndes, G. Sparovek, and S. Wirsenius. 2013. Agricultural intensification in Brazil and its effects on land-use patterns: An analysis of the 1975-2006 period. Glob. Chang. Biol. 19: 1804-1815.

BARTON, K. 2016. MuMIn: Multi-Model Inference. Available at: http://mumin.rforge.r-project.org/.

BINI, D. L. DE C. 2009. Mudanças na Composição das Culturas Agrícolas e a Urbanização na Região de Araçatuba. Informações Econ. 39: 63-75.

BranCALION, P.H.S., D. SCHWEIZER, U. GAUdARE, J.R. MANGUEIRA, F. LAMONATO, F.T. FARAH, A.G. NAVE, and R.R. RodRIGUES. 2016. Balancing economic costs and ecological outcomes of passive and active restoration in agricultural landscapes: the case of Brazil. Biotropica 48: 856-867.

BuRnHAM, K. P., and D. R. ANDERSON. 2002. Model selection and multimodel inference: a practical information-theoretic approach Second Edi. SpringerVerlag, New York.

CAmargo, A. M. M., and Z. A. P. SAntos. 1985. Mudança na composição agrícola paulista: o caso da soja, da laranja e da cana-de-açúcar. IEA: São Paulo. Available at: http://www.iea.sp.gov.br/out/TerTexto.php?codTexto=10619.

Carvalho, M. A., and C. R. L. Silva. 1987. Uma análise dos fatores que influenciaram a produção agrícola no Estado de São Paulo: alimentos x produtos exportáveis. IEA: São Paulo. Available at: http://www.iea.sp.gov.br/out/TerTexto.php?codTexto=10661.

Caser, D. V., L. C. Anefalos, A. M. M. . Camargo, M. P. A. Olivetti, and L. FAGUNDES. 1994. Evolução das principais atividades agrícolas do Estado de São Paulo, 1969 a 1992. IEA: São Paulo Available at: http://www.iea.sp.gov.br/out/anuarios.php.

CHABARIBERY, D. 1999. Inovação e desigualdade no desinvolvimento da agricultura paulista. Coleção Estud. Agrícolas 7: 1-178. Available at: 
http://www.iea.sp.gov.br/out/verTexto.php?codTexto=9623.

Chazdon, R. L., and M. R. Guariguata. 2016. Natural regeneration as a tool for large-scale forest restoration in the tropics:prospects and challenges. Biotropica 48: 716-730.

CRK, T., M. URIARTE, F. CORSI, and D. FLYNN. 2009. Forest recovery in a tropical landscape: What is the relative importance of biophysical, socioeconomic, and landscape variables? Landsc. Ecol. 24: 629-642.

DeFries, R. S., T. K. Rudel, M. URiarte, and M. HANSEN. 2010. Deforestation driven by urban population growth and agricultural trade in the twenty-first century. Nat. Geosci. 3: 178-181.

Egeskog, A., A. Barretto, G. Berndes, F. Freitas, M. Holmén, G. Sparovek, and J. TORÉM. 2016. Actions and opinions of Brazilian farms who shift to sugarcane - an interview-based assessment with discuss of implications for land-use change. Land Use Policy. 57: 594-604.

FARINACI, J. S. 2012. As novas matas do estado de São Paulo: um estudo multiescalar sob a perspectiva da Teoria da Transição Florestal. PhD Dissertation. Universidade Estadual de Campinas.

FARINACI, J. S., and M. BATISTELLA. 2012. Variação na cobertura vegetal nativa em São Paulo: um panorama do conhecimento atual. Rev. Árvore 36: 695-705.

FARINACI, J. S., L. C. FERREIRA, and M. BATISTELlA. 2013. Transição florestal e modernização ecológica: a eucaliptocultura para além do bem e do mal. Ambient. Soc. 16: 25-46.

Ferraz, S. F. B., K. M. P. M. B. Ferraz, C. C. Cassiano, P. H. S. Brancalion, D. T. A. DA LuZ, T. N. Azevedo, L. R. TAmbosi, and J. P. MetzGer. 2014. How good are tropical forest patches for ecosystem services provisioning? Landsc. Ecol. 29: 187:200.

Foley, J. A., R. Defries, G. P. Asner, C. BARford, G. Bonan, S. R. CARpenter, F. S. Chapin, M. T. Coe, G. C. Daily, H. K. GibBs, J. H. Helkowski, T. Holloway, E. a Howard, C. J. Kucharik, C. Monfreda, J. A. Patz, I. C. PRENTICE, N. RAMANKUTTY, and P. K. SNYDER. 2005. Global consequences of land use. Science 309: 570-4.

Freitas, S. R., C. O. M. Sousa, D. Boscolo, and J. P. MetzGer. 2013. How are native vegetation and reserves affected by different road types in a 
southeastern Brazilian state? Oecologia Aust. 17: 447-458.

FreitAs, S. R., T. J. HAWBAKER, and J. P. METZGER. 2010. Effects of roads, topography, and land use on forest cover dynamics in the Brazilian Atlantic Forest. For. Ecol. Manage. 259: 410-417.

GARCIA, A. E. B. 1986. Ocupação da mão-de-obra na agricultura do Estado de São Paulo na década de 70. IEA: São Paulo. Available at: ftp://ftp.sp.gov.br/ftpiea/rea/tomo1_2_85.

GeIST, H. J., and E. F. LAMBIN. 2002. Proximate causes and underlying driving forces of tropical deforestation. Bioscience 52: 143-150.

Gelman, A., and J. HILl. 2007. Data analysis using regression and multilevel/hierarchical model. First Edt. Cambridge University Press, Cambridge, UK.

GHILARD, A. A. 1986. Transformações na agricultura paulista na década de setenta, ao nível de tamanho de propriedade. IEA: São Paulo. Available at: http://www.iea.sp.gov.br/out/TerTexto.php?codTexto=10677.

Gibbs, H. K., A. S. Ruesc, F. Achard, M. K. Clayton, P. Holmgren, N. RAMANKUTTY, and J. A. Foley. 2010. Tropical forests were the primary sources of new agricultural land in 1980s and 1990s. PNAS. 107(38): 1673216737.

HOLL, K. D. 1999. Factors limiting tropical rain forest regeneration in abandoned pasture: seed rain, seed germination, microclimate, and soil. Biotropica 31: $229-242$.

HoOPer, E., P. LEGENDRE, and R. CONDIT. 2004. Factors Affecting Community Composition of Forest Regeneration in Deforested, Abandoned Land in Panama. Ecology 85: 3313-3326.

Hosonuma, N., M. Herold, V. De Sy, R. S. DeFries, M. Brockhaus, L. Verchot, A. Angelsen, and E. Romisn. 2012. An assessment of deforestation and forest degradation drivers in developing countries. Environ. Res. Lett. 7: 044009.

IGARI, A.T., L.R. TAMBOSI, and V.R. PIVELLO. 2009. Agribusiness opportunity costs and environmental legal protection: investigating trade-off on hotspot preservation in the State of São Paulo, Brazil. Environ. Manage. 44: 346-355.

IGARI, A.T., and V.R. PIVELLO. 2012. Crédito Rural e Código Florestal: imãos como Caim e Abel? Ambiente e Sociedade 14:133-150. 
IBGE. 2011. Características da população e dos domicílios: resultados do universo. Rio de Janeiro. Available at: http://www.ibge.gov.br/home/estatistica/populacao/censo2010/default.shtm.

LAMBIN, E. F., and P. MEYFROIDT. 2010. Land use transitions: Socio-ecological feedback versus socio-economic change. Land Use Policy 27: 108-118.

Lapola, D. M., L. A. Martinelli, C.A. Peres et al. 2014. Pervasive transition of the Brazilian land-use system. Nat. Clim. Chang. 4: 27-35.

LEGENDRE, P., and L. LEGENDRE. 1998. Numerical Ecology Second Edi. Elsevier, Amsterdam.

LiRA, P. K., L. R. TAMbosi, R. M. EwERS, and J. P. METZGER. 2012. Land-use and land-cover change in Atlantic Forest landscapes. For. Ecol. Manage. 278: 8089.

MAIA, M. L. 1996. Citricultura Paulista: evolução, estrutura e acordo de preços. IEA: São Paulo. Available at: http://www.iea.sp.gov.br/out/verTexto.php?codTexto=10765

MARTINS, S. S. 1986. Agricultura paulista: da modernização à crise. IEA: São Paulo. Available at: http://www.iea.sp.gov.br/out/verTexto.php?codTexto=10629

MAtheR, A.S., and C.L. NEedLE. 1998. The forest transition: a theoretical basis. Area 30:117-124.

Meyfroidt, P., and LAmbin, E. F.. 2011. Global land use change, economic globalization, and the looming land scarcity. PNAS. 108: 3465-3472.

Meyfroidt, P., K. M. CARLson, M. E. Fagan et al. 2014. Multiple pathways of commodity crop expansion in tropical forest landscapes. Environ. Res. Lett. 9: 074012.

Olivette, M. D. A., and F. P. De CAmargo. 2009. Concentração Fundiária no Estado de São Paulo, 1996-2008. Informações Econ. 39: 68-76.

PERZ, S. G. 2007. Grand theory and context-specificity in the study of forest dynamics: Forest transition theory and other directions. Prof. Geogr. 59: 105114 .

PFAFF, A., and R. WALKER. 2010. Regional interdependence and forest "transitions": Substitute deforestation limits the relevance of local reversals. Land Use Policy 27: 119-129.

R Development Core Team. 2016a. The R Stats Package. Available at: 
https://stat.ethz.ch/R-manual/R-devel/library/stats/html/00Index.html.

R Development Core TEAM. 2016b. R: A language and environment for statistical computing. Available at: https://www.r-project.org/

Redo, D. J., H. R. GraU, T. M. Aide, and M. L. Clark. 2012. Asymmetric forest transition driven by the interaction of socioeconomic development and environmental heterogeneity in Central America. Proc. Natl. Acad. Sci. U. S.

A. 109: 8839-44.

Ribeiro, M. C., J. P. Metzger, A. C. Martensen, F. J. Ponzoni, and M. M. Hirota. 2009. The Brazilian Atlantic Forest: How much is left, and how is the remaining forest distributed? Implications for conservation. Biol. Conserv. 142: 1141-1153.

Rietbergen-McCracken, J., S. Maginnis, and A. SARre. 2007. The forest landscape restoration handbook. Earthscan, London, UK.

Rudel, T.K., O.T. Coomes, E. Moran, F. Achard, A. Angelsen, J. Xu, and E. F. LAMBIN. 2005. Forest transitions: towards a global understanding of land use change. Glob. Environ. Change. 15: 23-31.

RUDEL, T. K. 2015. Have tropical deforestation's changing dynamics created conservation opportunities? A historical analysis. Environ. Conserv. 42: 108:118.

SILVA, C. R. L. 1983. A crise energética e o PROÁLCOOL: algumas configurações. IEA: São Paulo. Available at: http://www.iea.sp.gov.br/ftpiea/RP/1983/relat1183.pdf.

Silva, W. G., J. P. MetzGer, S. SimÕeS, and C. SimOnETti. 2007. Relief influence on the spatial distribution of the Atlantic Forest cover on the Ibiúna Plateau, SP. Brazilian J. Biol. 67: 403-411.

Silva, R. F. B., M. Batistella, and E. F. Moran. 2016. Drivers of land change: human-environment interactions and the Atlantic forest transition in the Paraíba Valley, Brazil. Land Use Policy 58: 133-144.

SOS, and INPE. 2015. Atlas dos Remanescentes Florestais da Mata Atlântica: Período 2013-2014. 2015. Sao Paulo, SP Available at http://mapas.sosma.org.br/dados/\#.

Sparovek, G., G. Berndes, A. Egeskog, F. L. M. Freitas, S. Gustafsson, and J. HANSSON. 2007. Sugarcane ethanol production in Brazil: an expansion model 
sensitive to socioeconomic and environmental concerns. Biofuels, Bioprod. Biorefining 1: 270-282.

Teixeira, A. M. G., B. S. SoAres-Filho, S. R. Freitas, and J. P. MetZger. 2009. Modeling landscape dynamics in an Atlantic Rainforest region: Implications for conservation. For. Ecol. Manage. 257: 1219-1230.

Thomlinson, J. R., M. I. SERrano, T. D. LOPEZ, T. M. Aide, and J. K. Zimmerman. 1996. Land-use dynamics in a post-agricultural Puerto Rican landscape (19361988). Biotropica 28: 525-536.

Vegro, C. L. R., N. B. MARTin, and L. MoriCOCHI. 2000. Sistemas de produção competitividade da cafeicultura paulista. Informações Econômicas 30: 7-44.

VeIGA, J. E. R., and M. N. OTANI. 1983. Relações de trabalho na agricultura paulista: o declínio da mão-de-obra permanente. IEA: São Paulo. Available at: http://www.iea.sp.gov.br/out/LerTexto.php?codTexto=12011.

VIANA, M. B. 2004. O eucalipto e os efeitos ambientais do seu plantio em escala. Câmara dos Deputados: Brasília. Available at: http://bd.camara.gov.br/bd/handle/bdcamara/1162

WALKER, R. 2012. The scale of forest transition: Amazonia and the Atlantic forests of Brazil. Appl. Geogr. 32: 12-20.

Yackulic, C. B., M. FAgan, M. Jain, Y. Lim, M. Marlier, R. Muscarella, P. AdAME, R. DeFries, and M. URIARTE. 2011. Biophysical and Socioeconomic Factors Associated with Forest Transitions at Multiple Spatial and Temporal Scales. Ecol. Soc. 16: 15. 
TABLE 1 . Explanatory variables considered in the models and hypothesized relationship with forest cover change. Hypothesized relationship is indicated as positive (+) or negative (-).

\begin{tabular}{|c|c|c|c|}
\hline \multicolumn{2}{|c|}{$\begin{array}{l}\text { Explanatory } \\
\text { variables }\end{array}$} & \multirow{2}{*}{$\begin{array}{l}\text { Hypothesized } \\
\text { relationship } \\
-\end{array}$} & \multirow{2}{*}{$\begin{array}{l}\quad \text { Rationale for hypothesis } \\
\text { Non-farm jobs lead rural-to- } \\
\text { urban migration decreasing } \\
\text { density of workers and leading } \\
\text { to lands abandonment (Rudel et } \\
\text { al. } 2005 \text { ) }\end{array}$} \\
\hline Socioeconomic & $\begin{array}{l}\text { Density of farm } \\
\text { workers }\end{array}$ & & \\
\hline & $\begin{array}{l}\text { Pasture (extensive } \\
\text { livestock) }(\%)\end{array}$ & - & $\begin{array}{l}\text { Low-productivity cattle } \\
\text { ranching occupies as much area } \\
\text { as possible. }\end{array}$ \\
\hline & $\begin{array}{l}\text { Uncultivated } \\
\text { lands }(\%)\end{array}$ & + & $\begin{array}{l}\text { Agriculture concentrates in the } \\
\text { most suitable regions and } \\
\text { unprofitable lands are } \\
\text { abandoned (Lambin \& } \\
\text { Meyfroidt 2010). }\end{array}$ \\
\hline & Annual crops (\%) & - & $\begin{array}{l}\text { Annual crops as soybean and } \\
\text { sugarcane were economically } \\
\text { important between } 1960 \text { and } \\
2006 \text { and expanded } \\
\text { significantly during that period } \\
\text { (Chabaribery 1999) }\end{array}$ \\
\hline & $\begin{array}{l}\text { Perennial crops } \\
(\%)\end{array}$ & + & $\begin{array}{l}\text { More permanent land-use has } \\
\text { lower impact on forest cover }\end{array}$ \\
\hline & $\begin{array}{l}\text { Exotic tree } \\
\text { plantation }(\%)\end{array}$ & + & $\begin{array}{l}\text { Managed tree plantations can } \\
\text { facilitate forest recovery due to } \\
\text { environmental certification that } \\
\text { demands environmental law } \\
\text { compliance (Silva et al. } 2016 \text { ) }\end{array}$ \\
\hline & $\begin{array}{l}\text { Establishments } \\
\text { that used fertilizer } \\
(\%)\end{array}$ & + & $\begin{array}{l}\text { Land-saving practices can } \\
\text { reduce the demand for new } \\
\text { cleared land (Barretto et al. } \\
\text { 2013) }\end{array}$ \\
\hline & $\begin{array}{l}\text { Tractors per area } \\
\text { (unit/ha) }\end{array}$ & + & $\begin{array}{l}\text { Improving agricultural } \\
\text { technology increase production } \\
\text { and decrease the demand for } \\
\text { land (Barretto et al. 2013) }\end{array}$ \\
\hline \multirow[t]{3}{*}{ Biophysical } & $\begin{array}{l}\text { Mean slope } \\
\text { degree }(\%)\end{array}$ & + & $\begin{array}{l}\text { Steeper slopes are more likely } \\
\text { to regenerate (Silva et al. } 2007 \text {, } \\
\text { Teixeira } \text { et al. 2009) }\end{array}$ \\
\hline & $\begin{array}{l}\text { Water retention } \\
\text { capacity of soil }\end{array}$ & + & $\begin{array}{l}\text { Soils with higher water } \\
\text { retention capacity are more } \\
\text { likely occupied by agriculture }\end{array}$ \\
\hline & $\begin{array}{l}\text { Forest cover at the } \\
\text { start of the } \\
\text { interval }(\%)\end{array}$ & + & $\begin{array}{l}\text { Close proximity to seed sources } \\
\text { accelerates forest regrowth } \\
\text { (Holl 1999) }\end{array}$ \\
\hline
\end{tabular}


TABLE 2. Selected forest cover change models selected for each of four time periods. Explanatory variables include ratio of annual crop (AC), ratio of perennial crop (PC), ratio of pasture area (PT), ratio of exotic tree plantation (ET), ratio of uncultivated land area (UL), farms that used fertilizer (FU), ratio of density of workers on farms (DF), average slope (SD), soil water retention capacity (SWR), percentage of forest cover at the start of the interval (FC). $\mathrm{N}$ denotes the number of municipalities included in each model.

\begin{tabular}{lllll}
\hline Period & Explanatory variables & AIC & $\Delta$ AIC & Weight \\
\hline $1960-1970$ & AC+PC+PT+SD+SWR+FC & 636.8 & 0.00 & 1 \\
$1970-1980$ & PT+DF+SD+SWR+FC & 633.3 & 0.00 & 1 \\
& & & \\
$1980-1996$ & PC+PT+ET+SD+SWR+FC & 632.1 & 0.00 & 0.73 \\
$1996-2006$ & ET+UL+FU+SD+FC & -112.6 & 0.00 & 1 \\
\hline
\end{tabular}


A)

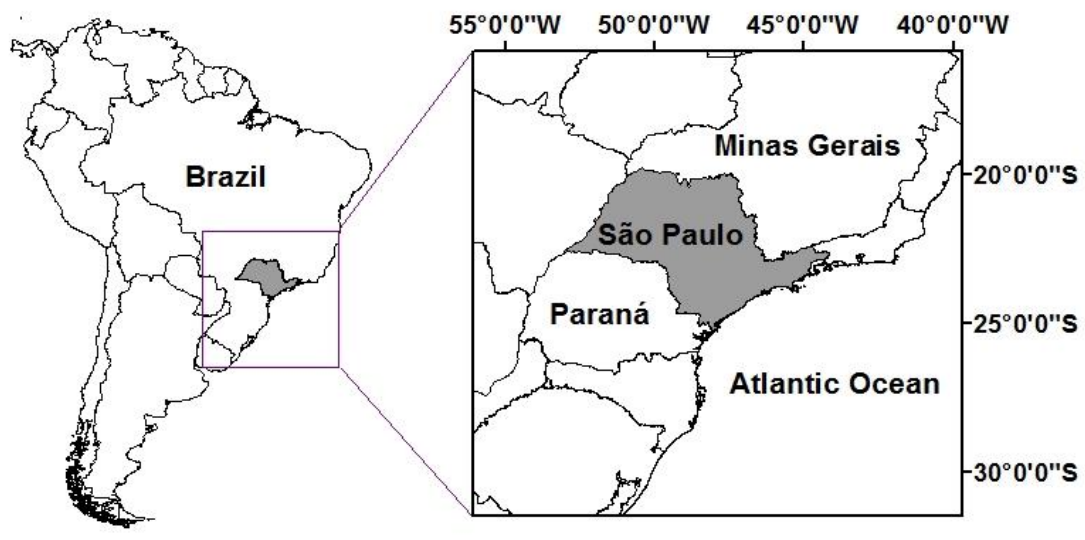

B)

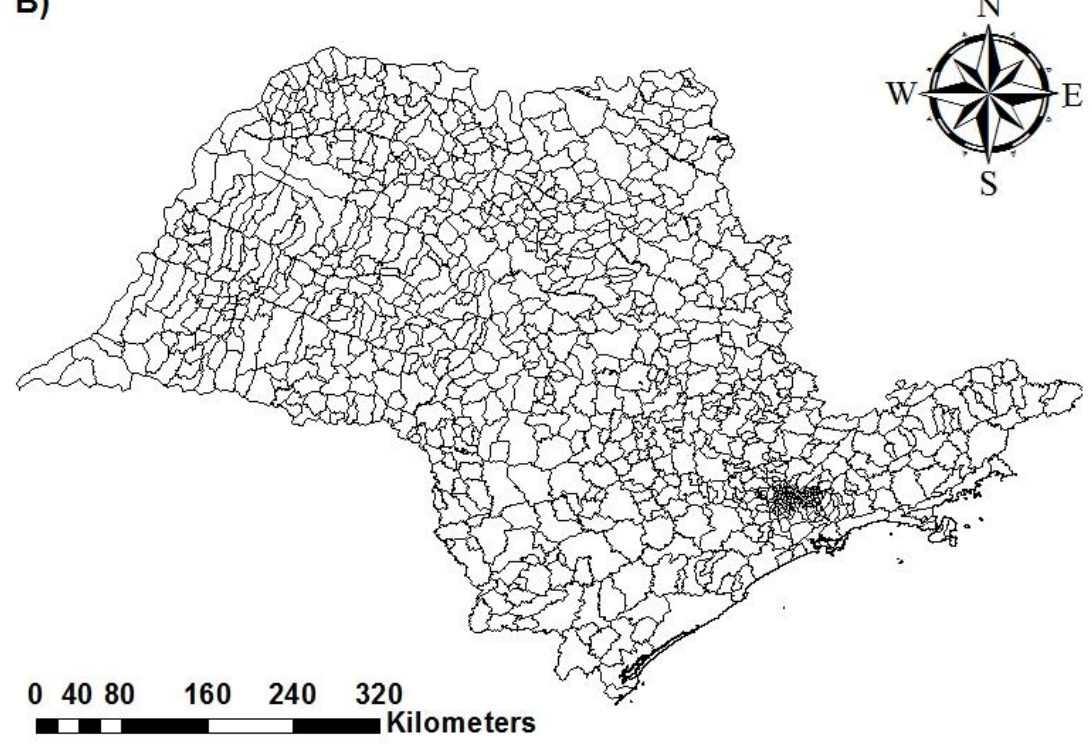

FIGURE 1. The state of São Paulo, Brazil (A), and the 645 municipalities analyzed in this study (B). 

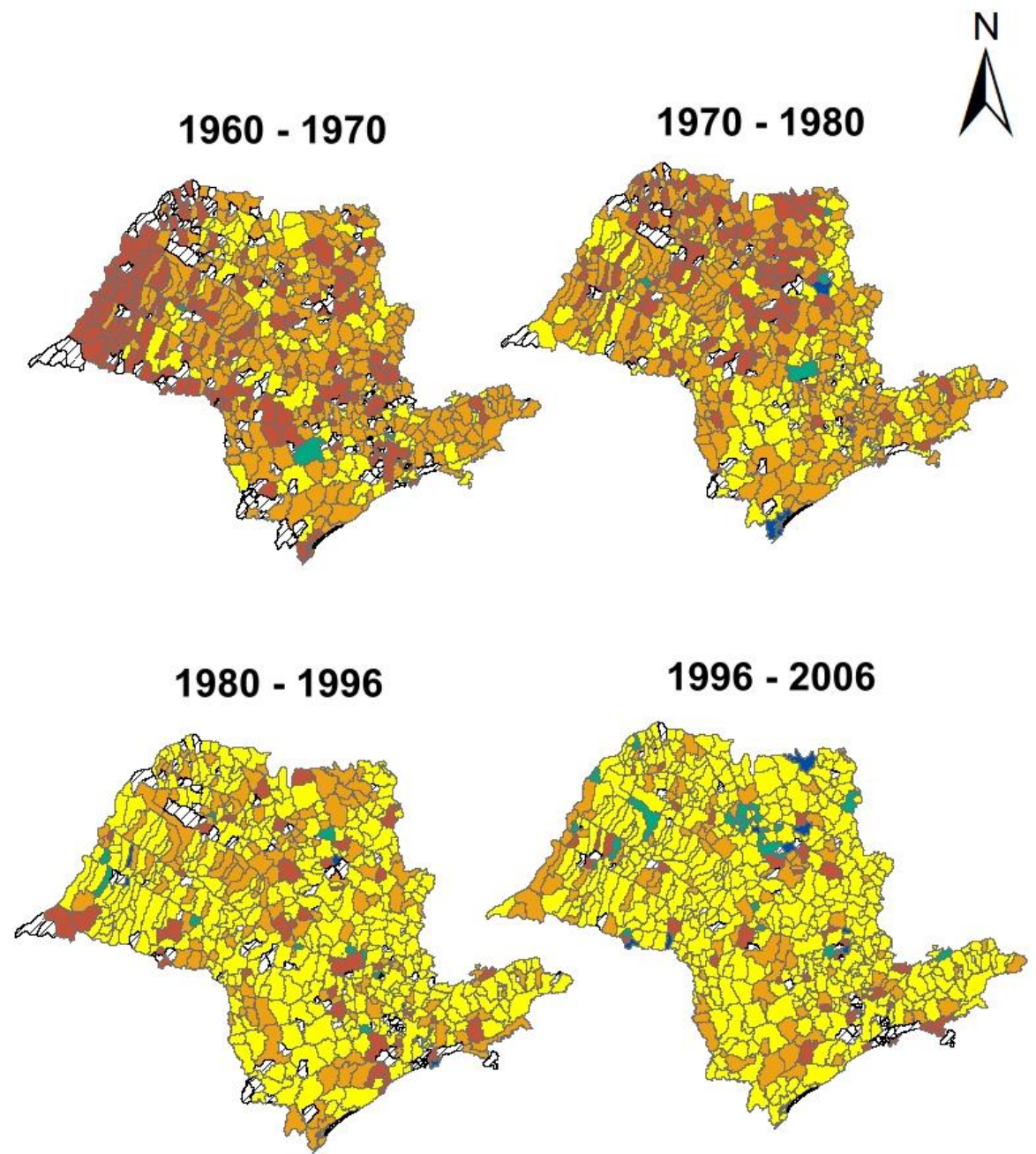

Forest Cover (ratio)

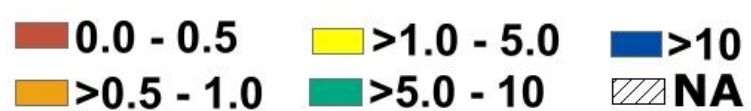

FIGURE 2. Forest cover ratio at the municipality-scale across São Paulo between 1960 and 2006. Municipality boundaries are shown in gray. Forest cover ratio was calculated by dividing forest cover values in one census by forest cover values of the previous census (e.g. FC in 1970/FC in 1960). Ratio values greater than 1 indicate that forest cover increased over the census interval and ratio values lower than 1 indicate that it decreased. (NA) Missing values. 

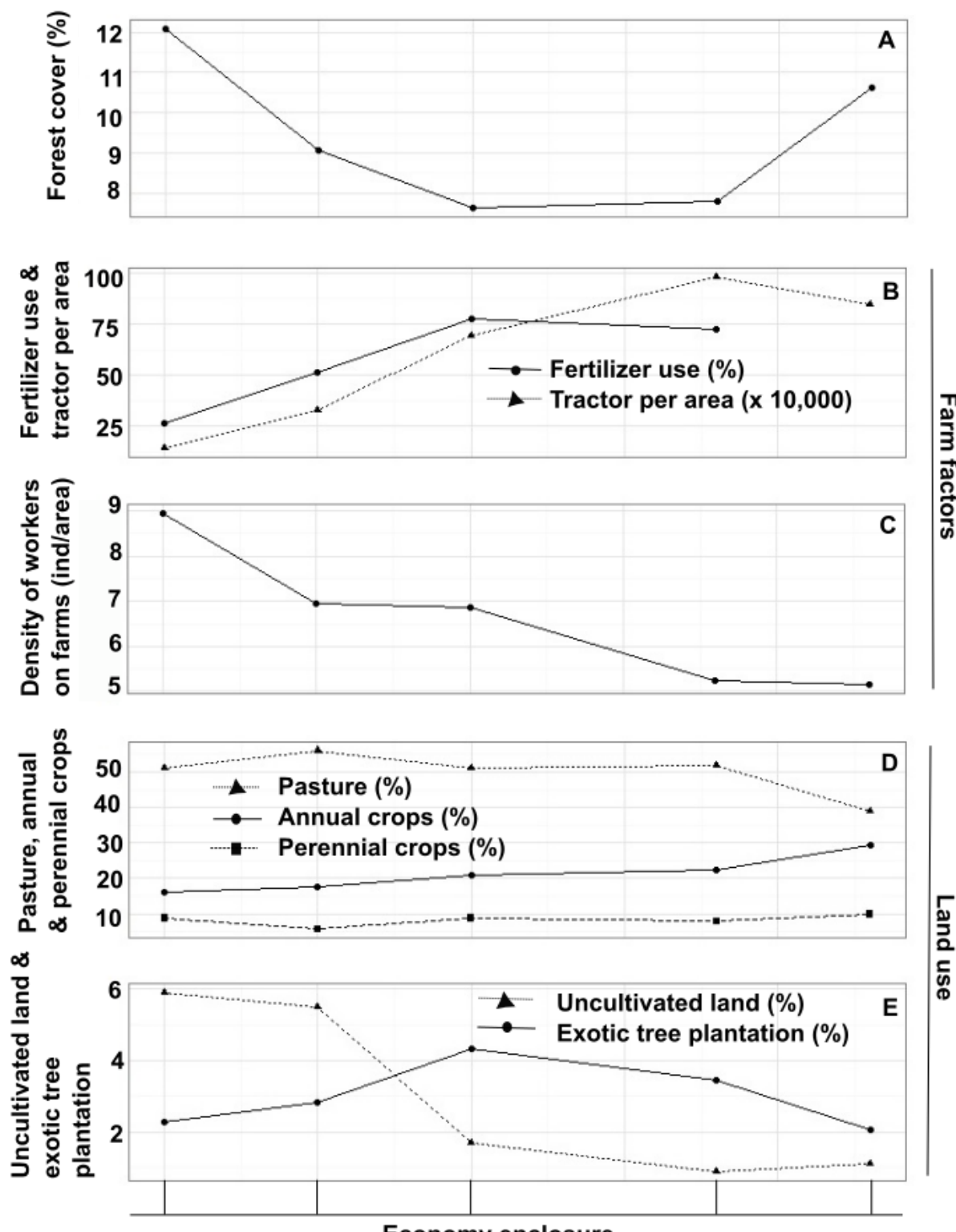

Economy enclosure

Military government

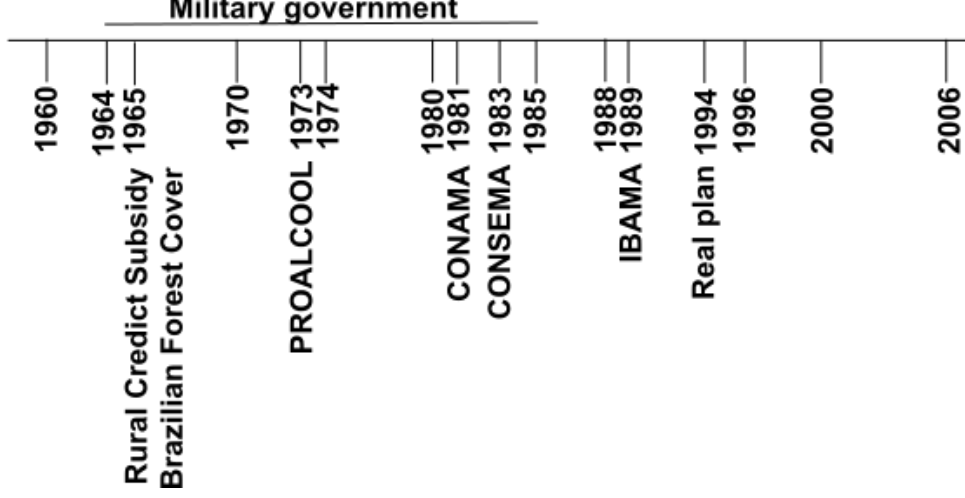

FIGURE 3. Temporal variation in total forest cover percentage (A), farm factors (B \& C) and land uses (D \& E) at the state scale, and the main political and economic events during the study period (1960-2006). 
A. $1960-1970$

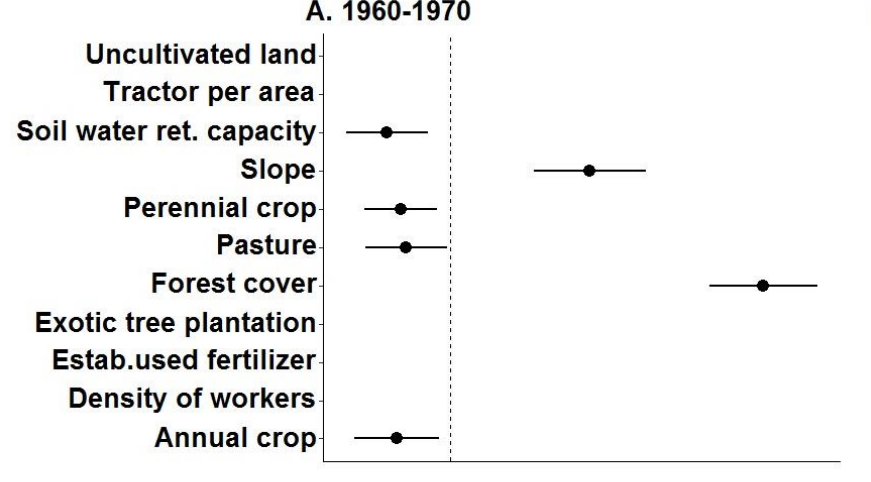

C. $1980-1996$

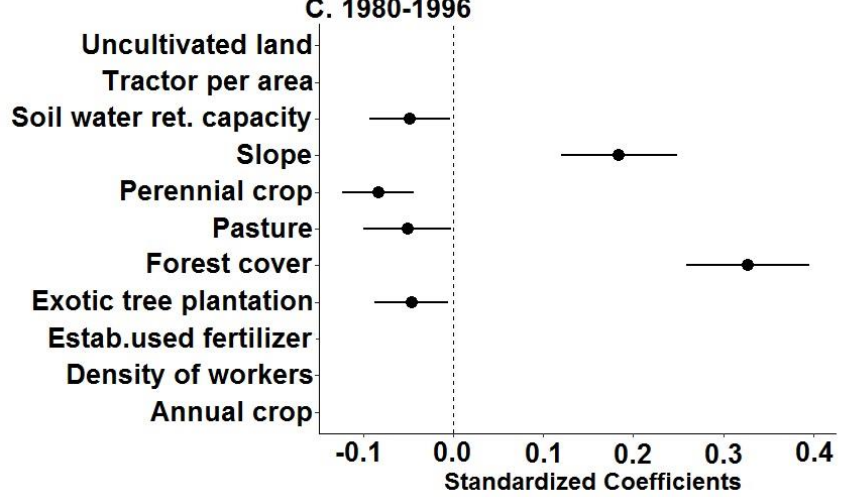

B. $1970-1980$

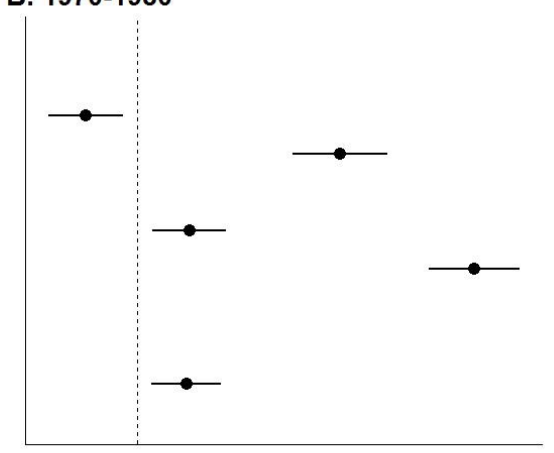

D. $1996-2006$

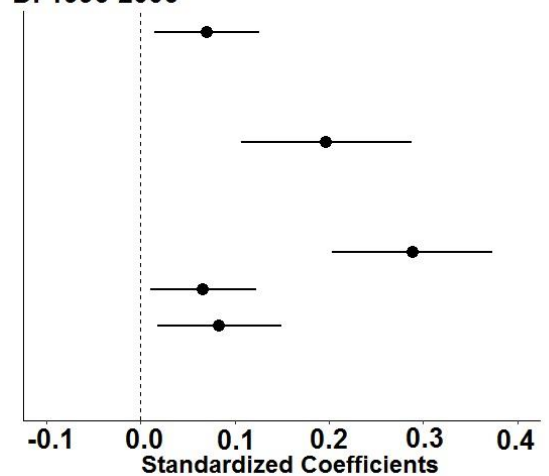

FIGURE 4. Mean parameters estimates (circles) and 2.5 - $97.5 \%$ confidence intervals (bars) for (A) 1960-1970, (B) 1970-1980, (C) 1980-1996, and (D) 1996-2006. The significance is based on CI values not overlapping zero. All coefficients present significant CI and are shown with black symbols. 

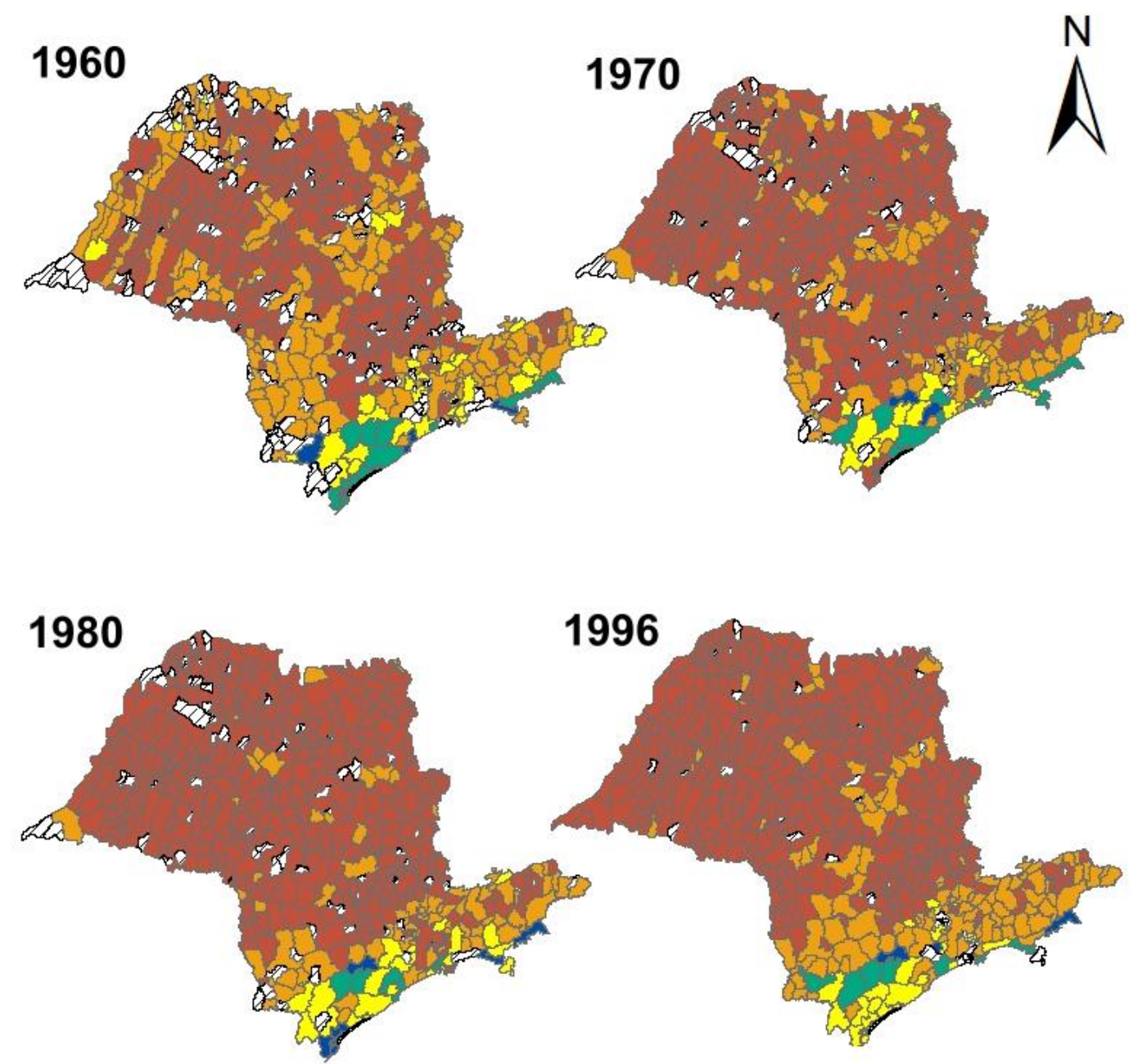

Forest Cover (\%)

$0.0-10$

$\square>10-30$

$\square>30-50$

$>50-70$

$>70-100$

VIIA NA

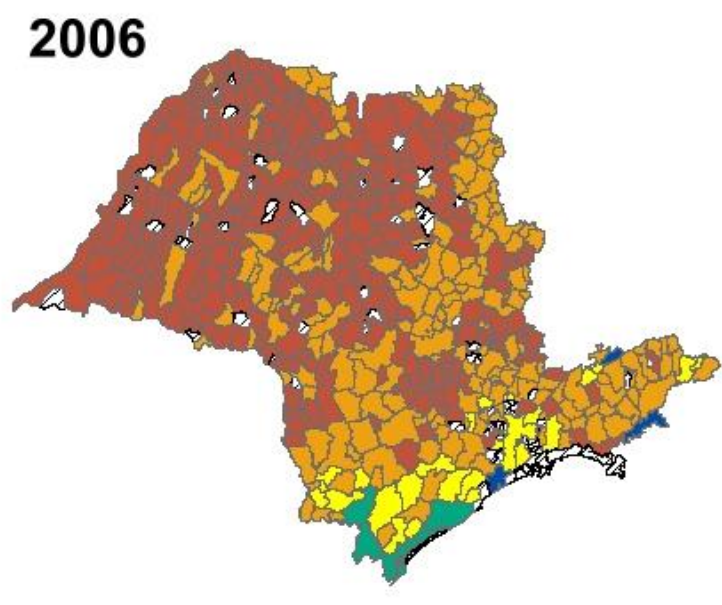

FIGURE S1. Percentage of forest cover at the municipality-scale for São Paulo state calculated for the years 1960, 1970, 1980, 1996 and 2006. Municipality boundaries are shown in gray. (NA) Missing values. 

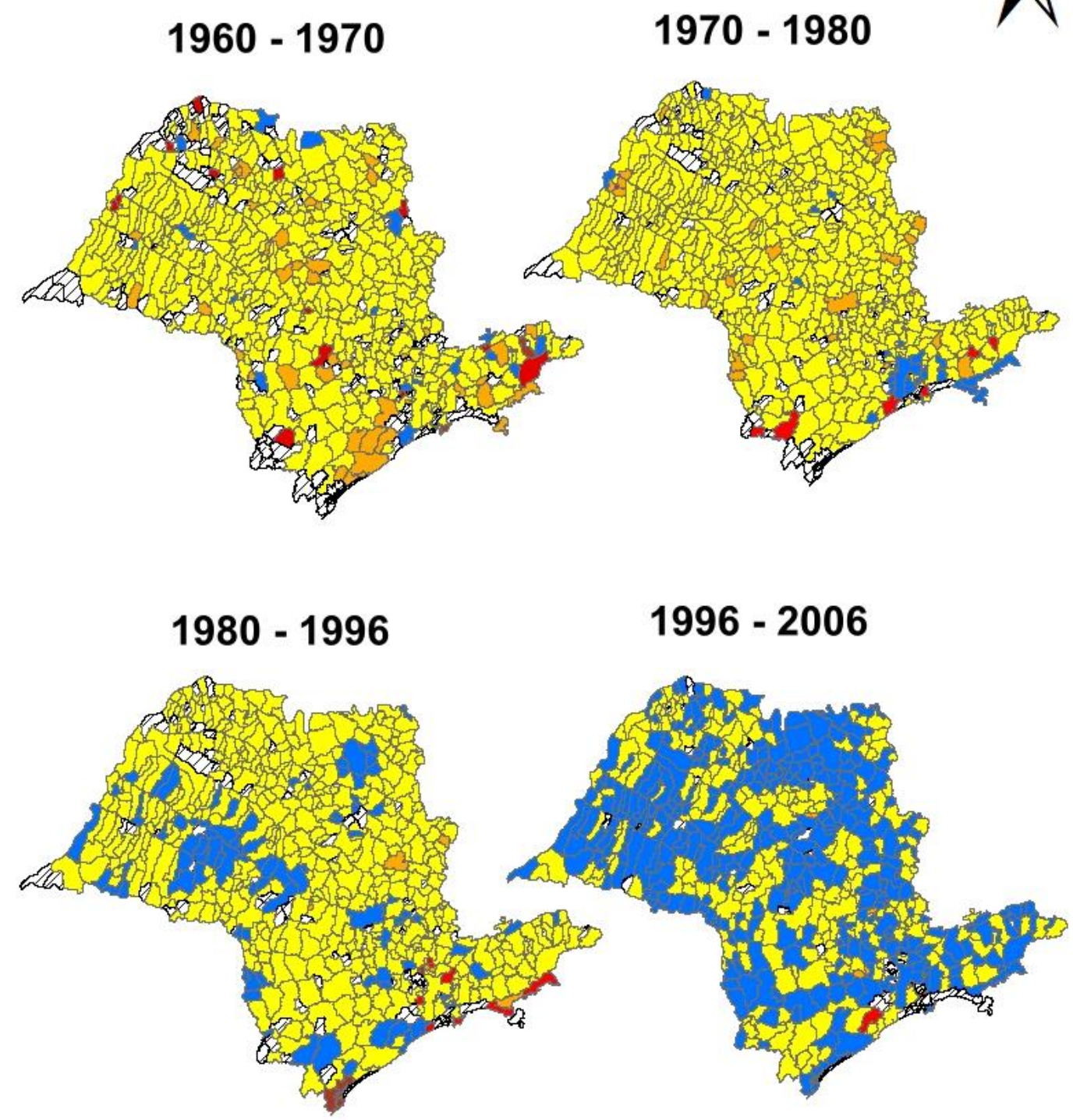

\section{Tractor per area (ratio)}

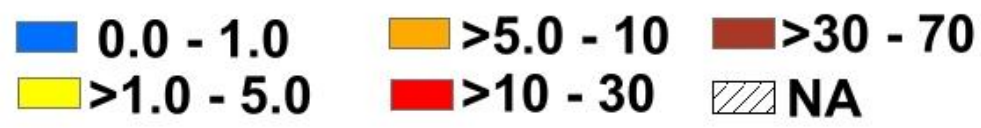

FIGURE S2. Tractors per area ratio at the municipality-scale for São Paulo state calculated for the intervals 1960-1970, 1970-1980, 1980-1996 and 1996-2006. The ratio of tractors per area was calculated by dividing the values of tractors per area of one census by the values of tractors per area of the previous census (e.g. values in 1970 / values in 1960). Ratio values greater than 1 (one) indicate that tractors per area increased over the census interval and values lower than 1 (one) indicate that it decreased. Municipality boundaries are shown in gray. (NA) Missing values. 


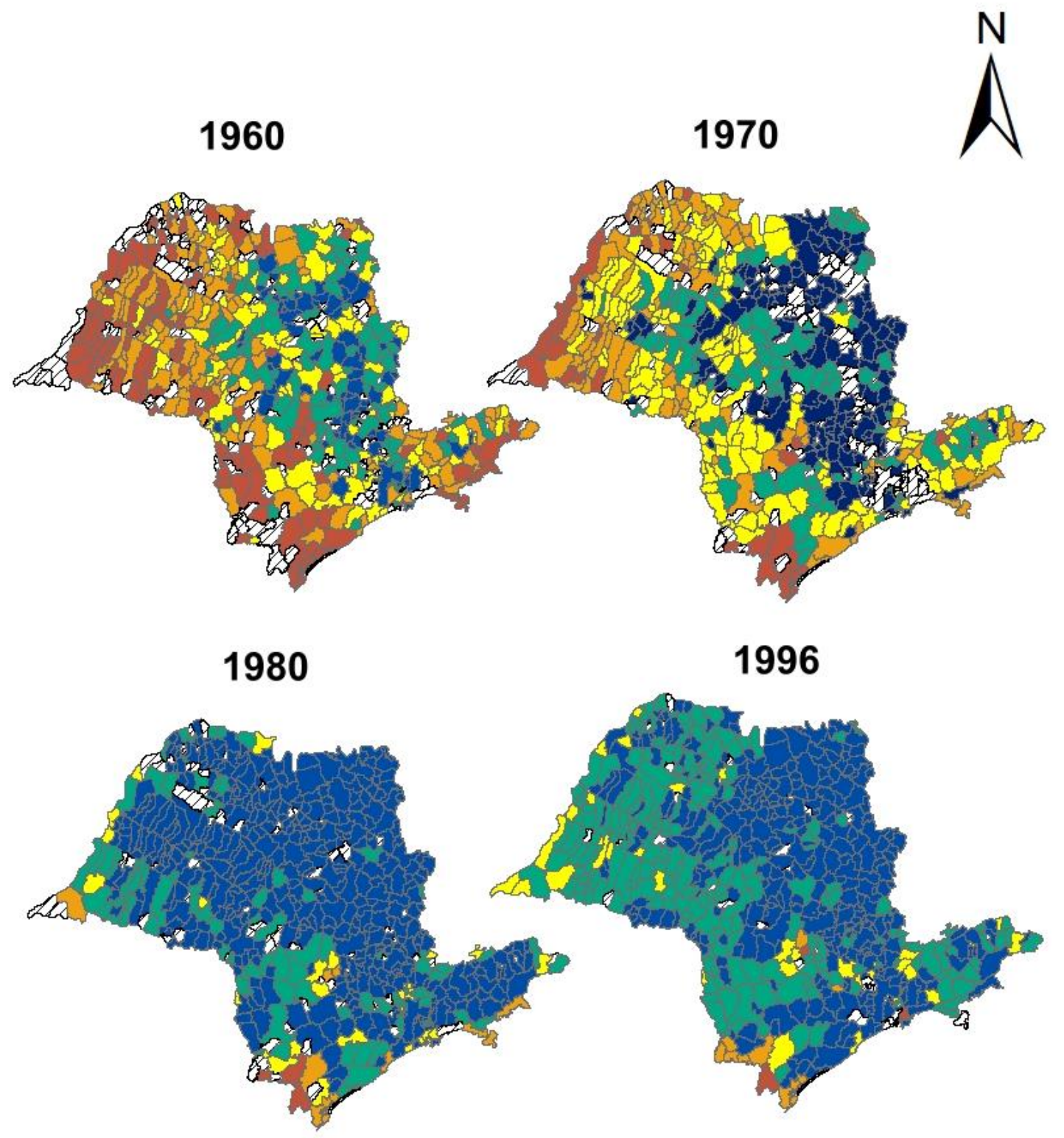

\section{Establishments that used fertilizer (\%)}

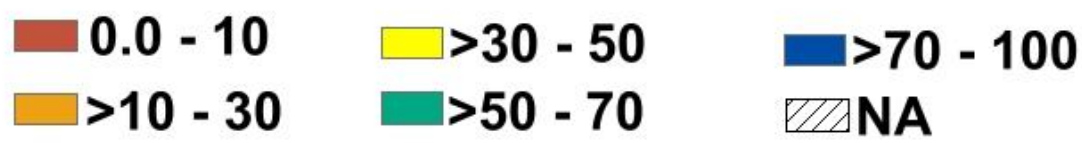

FIGURE S3. Percentage of establishments that used fertilizer at the municipality-scale for São Paulo state calculated for the years 1960, 1970, 1980 and 1996. Municipality boundaries are shown in gray. (NA) Missing values. 

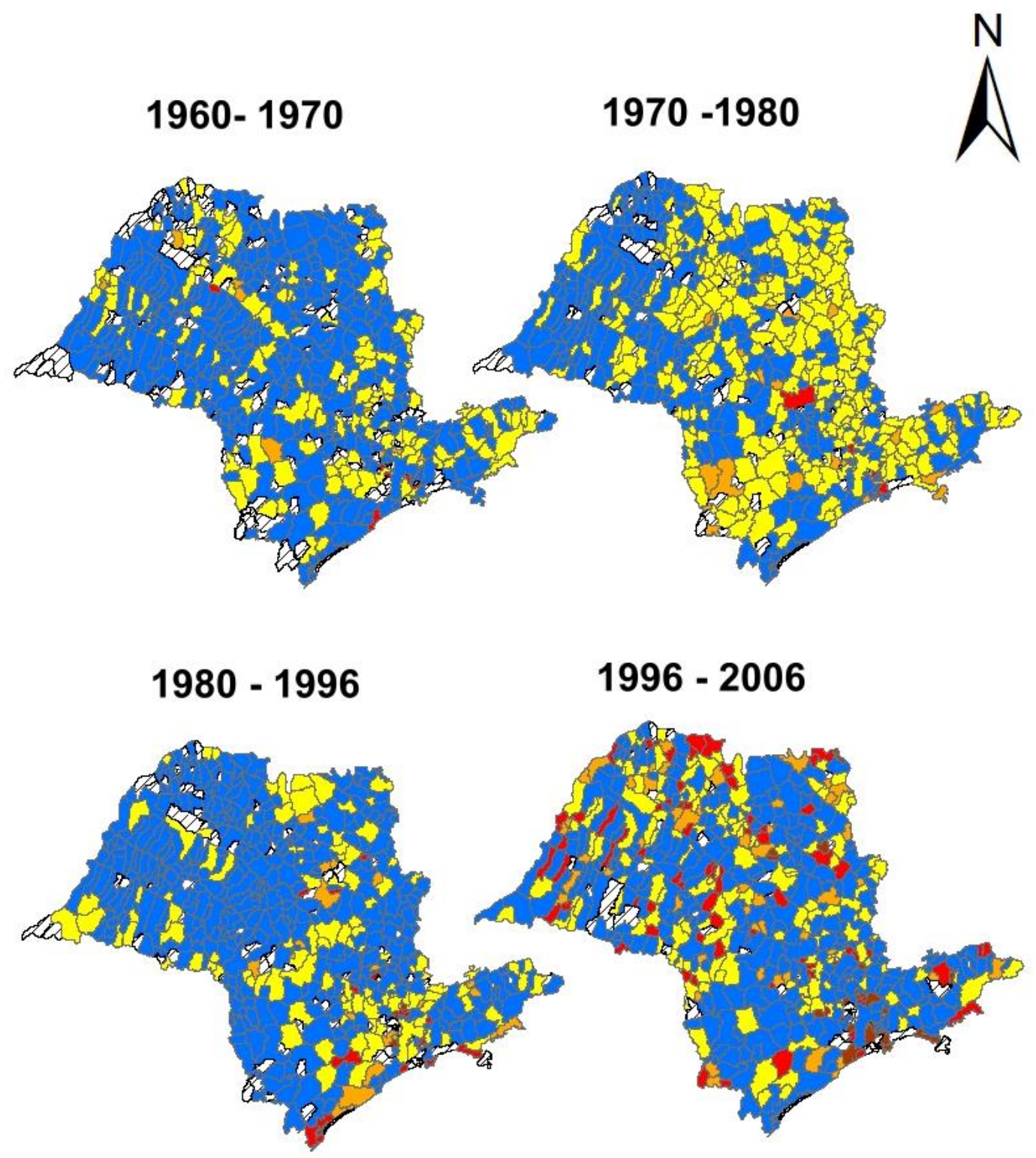

\section{Density of workers on farms (ratio)}

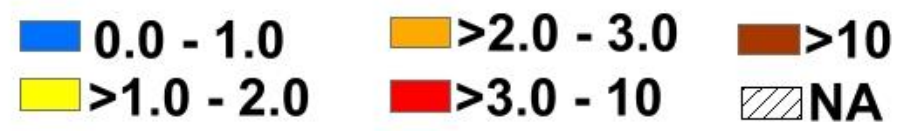

FIGURE S4. Density of workers on farms ratio at the municipality-scale for São Paulo state calculated for the intervals 1960-1970, 1970-1980, 1980-1996 and 1996-2006. Density of workers on farms ratio was calculated by dividing the density of workers in one census by the density of workers in the previous census (e.g. values in 1970 / values in 1960). Ratio values greater than 1 (one) indicate that density of workers increased over the census interval and values lower than 1 (one) indicate that it decreased. Municipality boundaries are shown in gray. (NA) Missing values. 

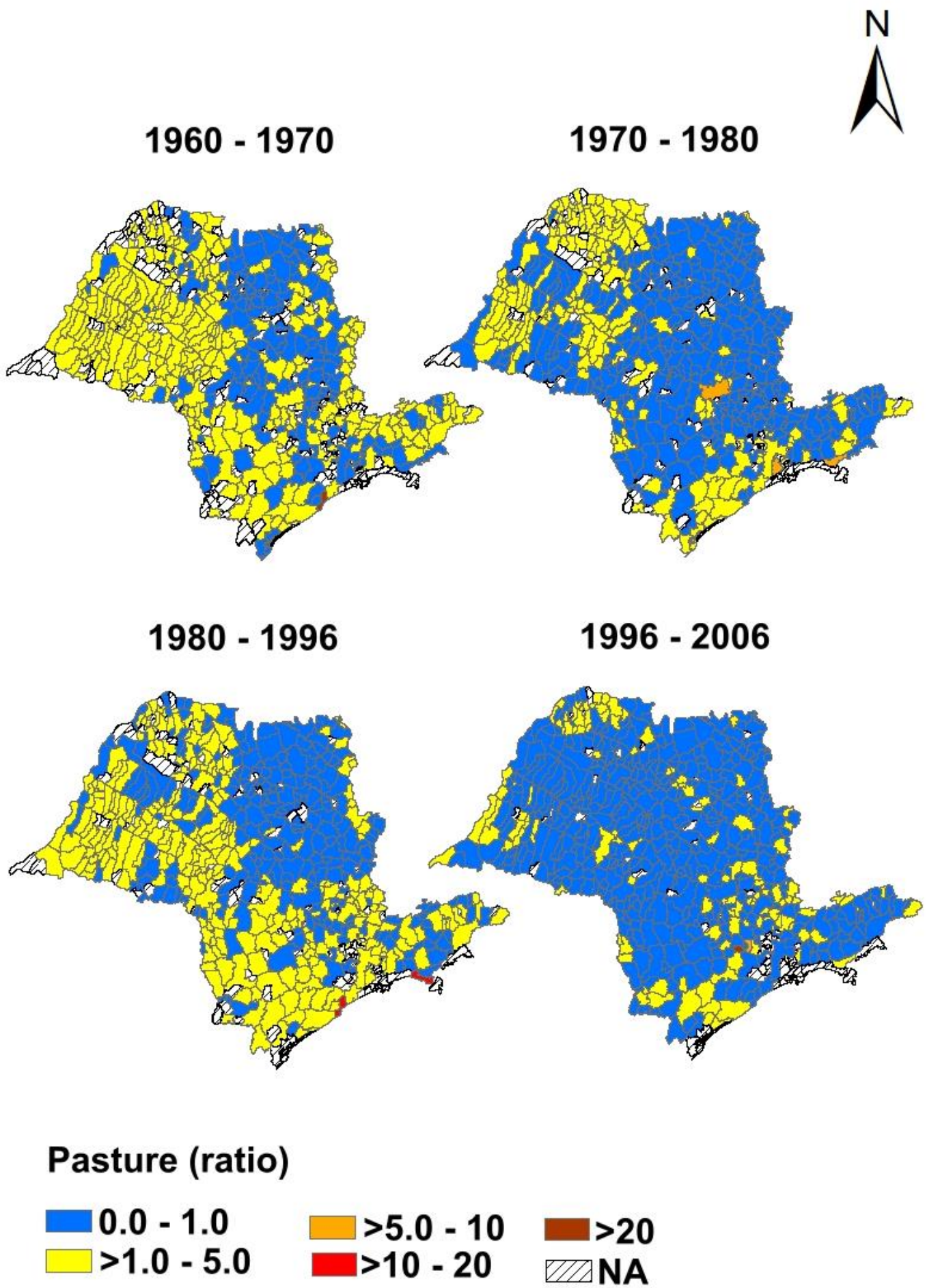

FIGURE S5. Pasture ratio at the municipality-scale for São Paulo state calculated for the intervals 1960-1970, 1970-1980, 1980-1996 and 1996-2006. Pasture ratio was calculated by dividing the pasture percentage in one census by pasture percentage in the previous census (e.g. values in 1970 / values in 1960). Ratio values greater than 1 (one) indicate that pasture increased over the census interval and values lower than 1 (one) indicate that it decreased. Municipality boundaries are shown in gray. (NA) Missing values. 

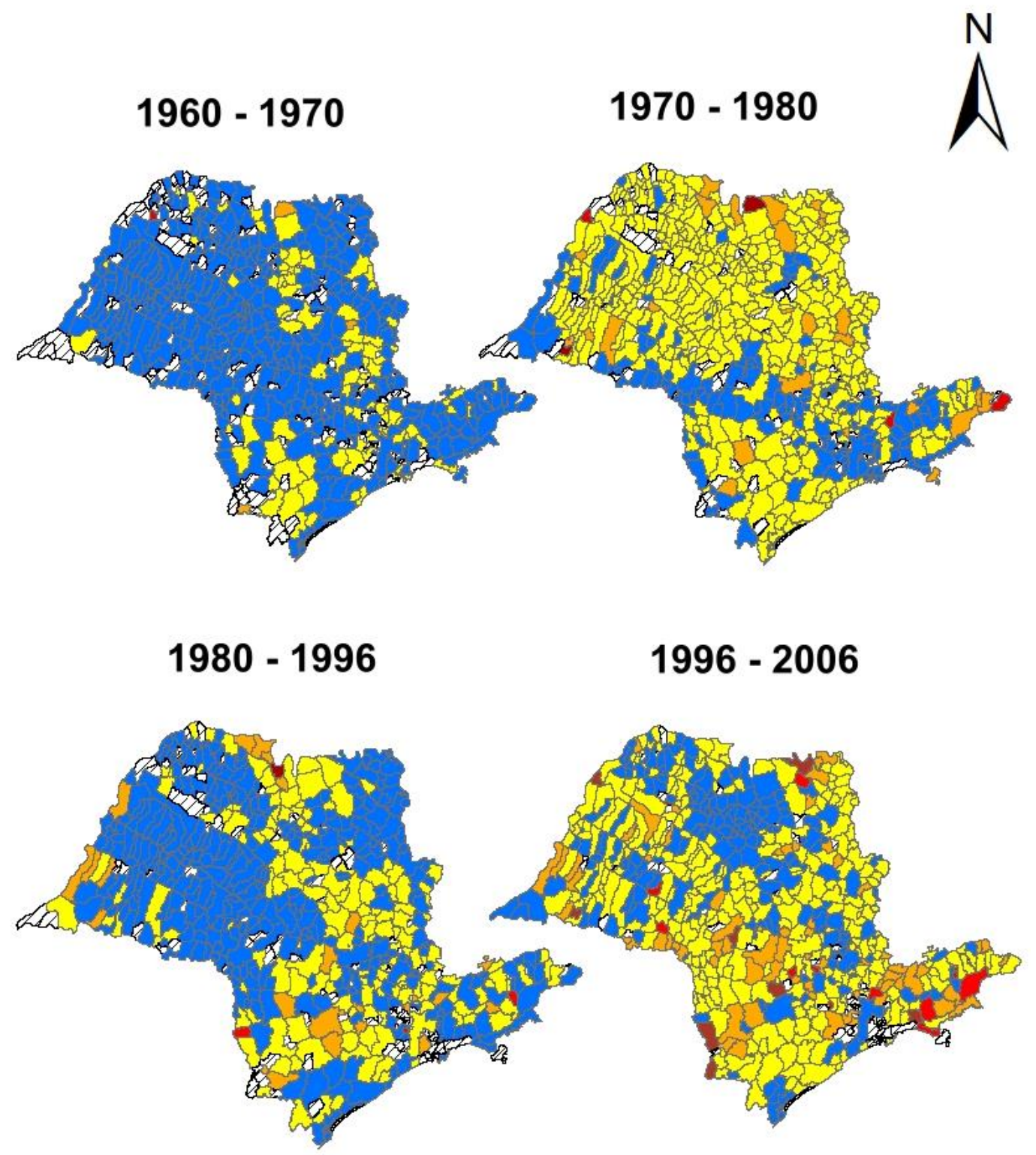

\section{Perennial crops (ratio)}
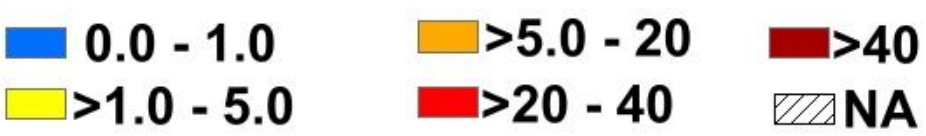

FIGURE S6. Perennial crop ratio at the municipality-scale for São Paulo state calculated for the intervals 1960-1970, 1970-1980, 1980-1996 and 1996-2006. Perennial crop ratio was calculated by dividing the perennial crop percentage in one census by perennial crop percentage in the previous census (e.g. values in 1970 / values in 1960). Ratio values greater than 1 (one) indicate that perennial crops increased over the census interval and values lower than 1 (one) indicate that it decreased. Municipality boundaries are shown in gray. (NA) Missing values. 

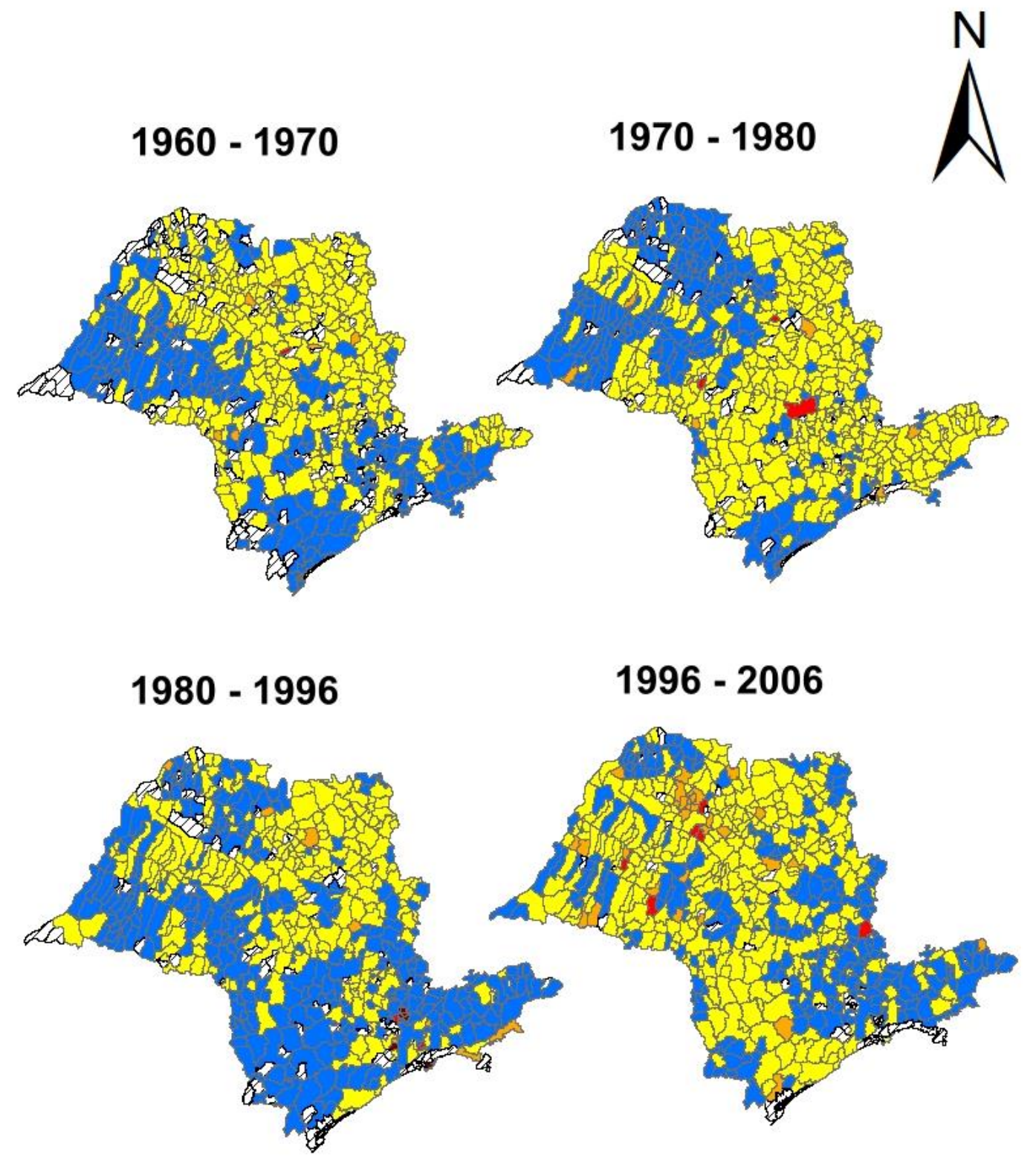

\section{Annual crops (ratio)}

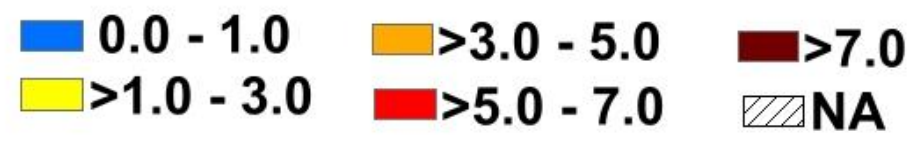

FIGURE S7. Annual crop ratio at the municipality-scale for Sao Paulo state calculated for the intervals 1960-1970, 1970-1980, 1980-1996 and 1996-2006. Annual crop ratio was calculated by dividing the annual crop percentage in one census by annual crop percentage in the previous census (e.g. values in 1970 / values in 1960). Ratio values greater than 1 (one) indicate that annual crops increased over the census interval and values lower than 1 (one) indicate that it decreased. Municipality boundaries are shown in gray. (NA) Missing values. 

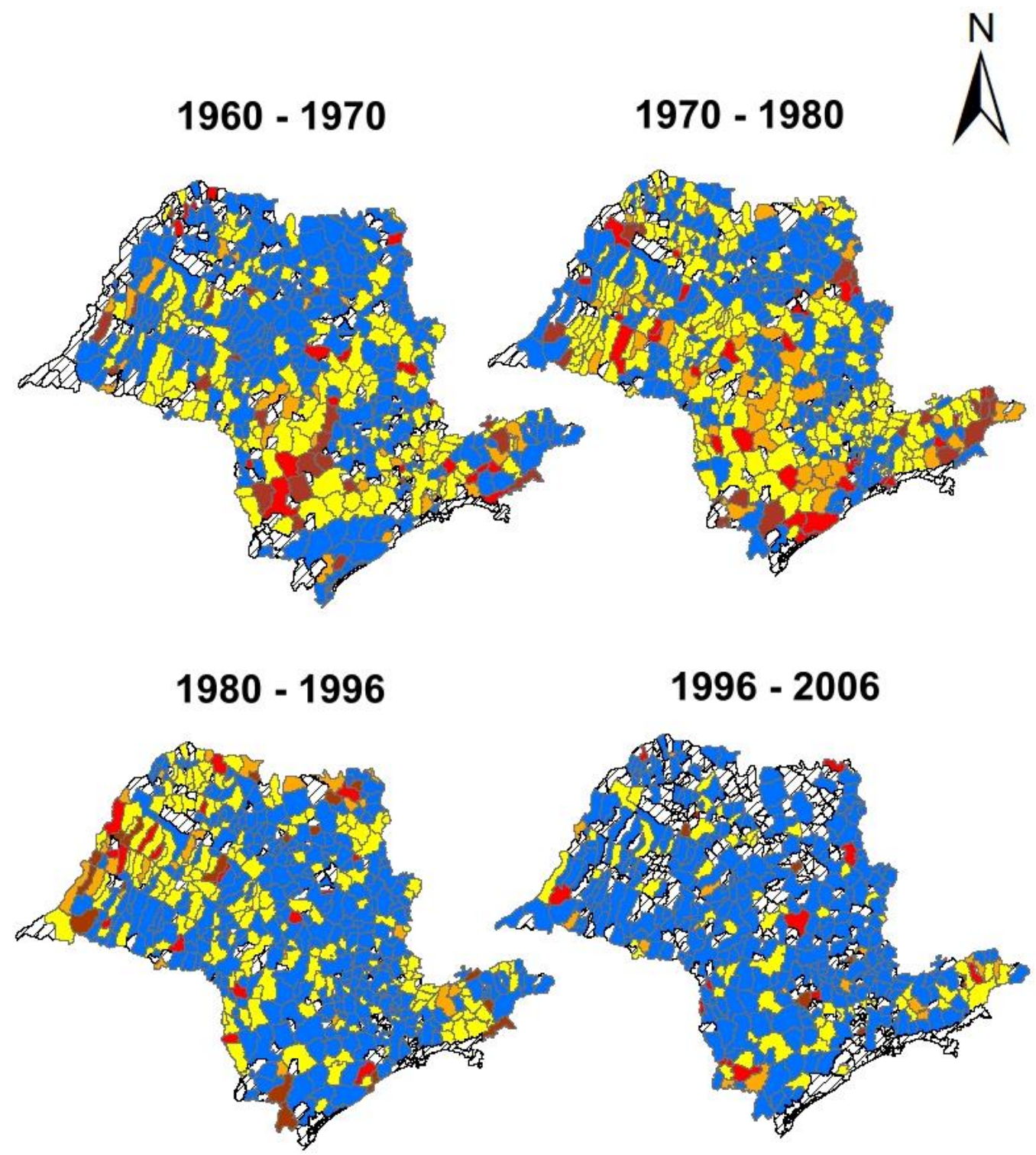

\section{Exotic tree plantion (ratio)}

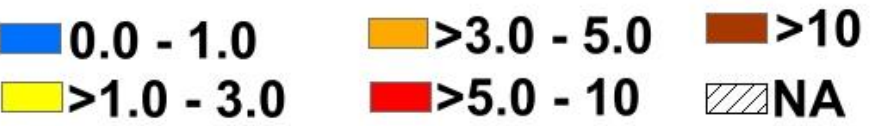

FIGURE S8. Exotic tree plantation ratio at the municipality-scale for São Paulo state calculated for the intervals 1960-1970, 1970-1980, 1980-1996 and 1996-2006. Exotic tree plantation ratio was calculated by dividing the percentage of exotic tree plantation in one census by the percentage of exotic tree plantation in the previous census (e.g. values in 1970 / values in 1960). Ratio values greater than 1 (one) indicate that exotic tree plantation increased over the census interval and values lower than 1 (one) indicate that it decreased. Municipality boundaries are shown in gray. (NA) Missing values. 

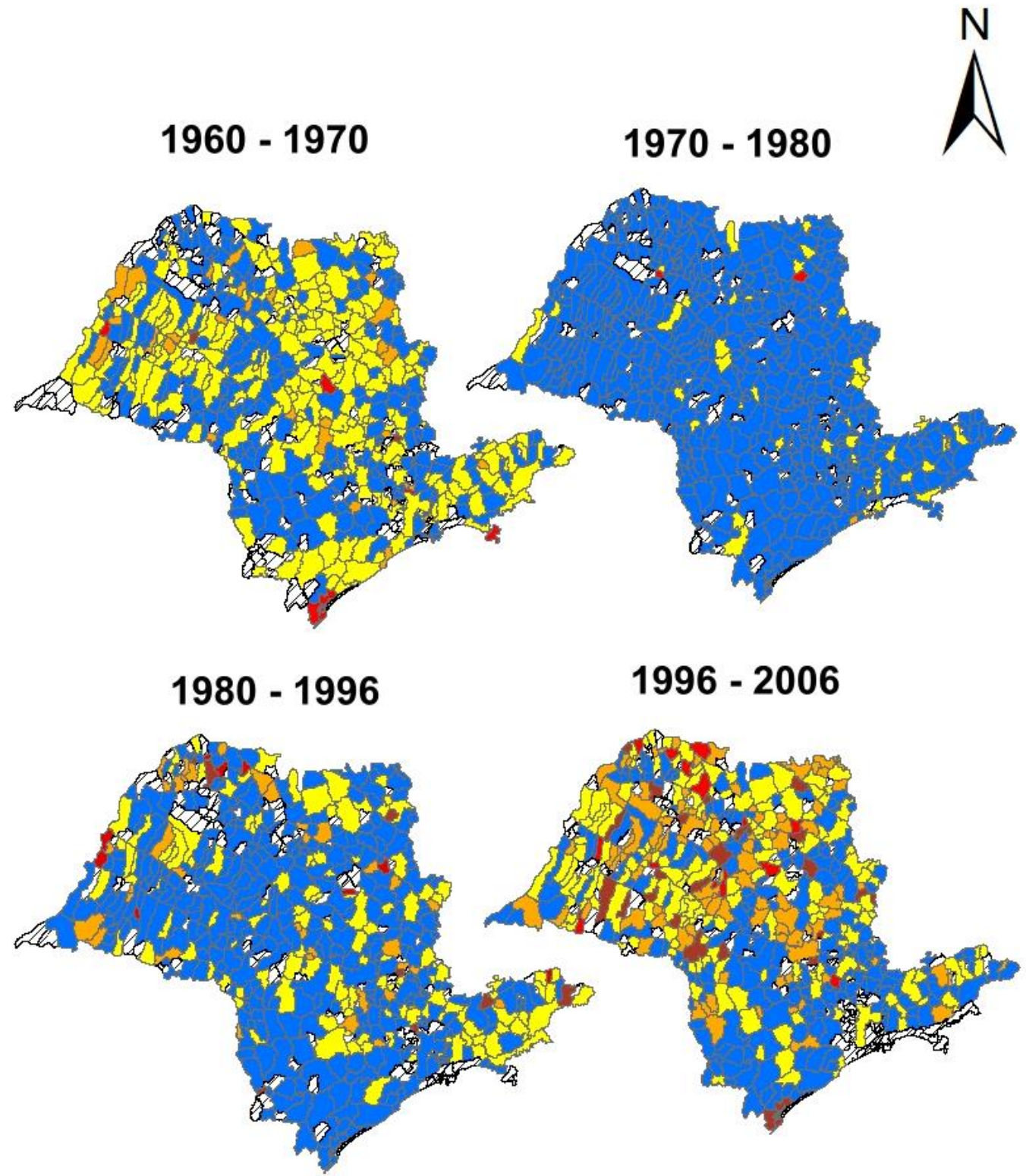

\section{Uncultivated land (ratio)}

$\begin{array}{llr}0.0-1.0 & \square 5.0-20 & >40 \\ \square>1.0-5.0 & >20-40 & \text { एवNA }\end{array}$

FIGURE S9. Uncultivated land ratio at the municipality-scale for São Paulo state calculated for the intervals 1960-1970, 1970-1980, 1980-1996 and 1996-2006.

Uncultivated land ratio was calculated by dividing the uncultivated land percentage in one census by uncultivated land percentage in the previous census (e.g. values in 1970 / values in 1960). Ratio values greater than 1 (one) indicate that uncultivated land increased over the census interval and values lower than 1 (one) indicate that it decreased. Municipality boundaries are shown in gray. (NA) Missing values. 


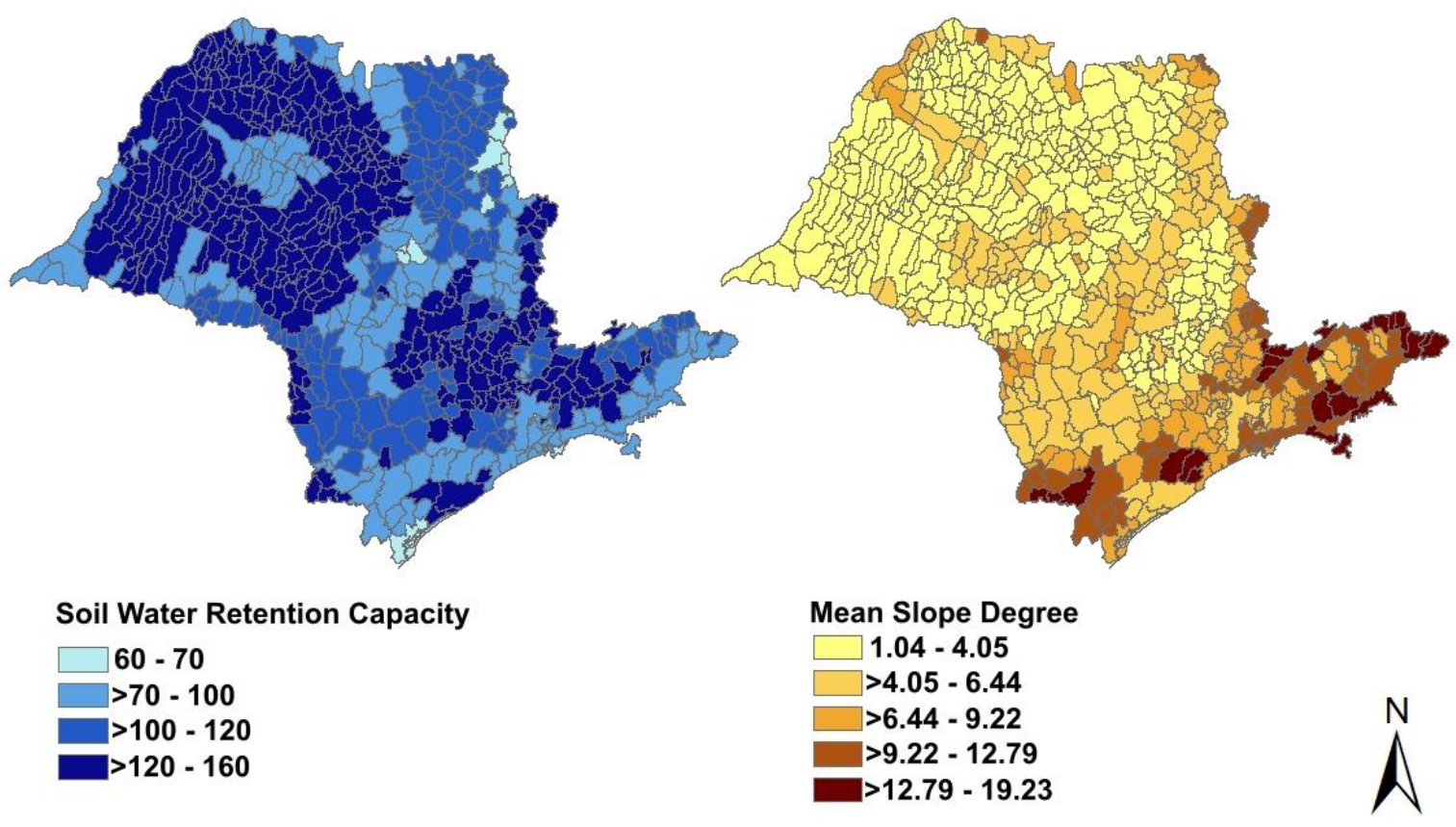

FIGURE S10. Soil water retention capacity and mean slope degree at the municipality-scale for the state of São Paulo. Municipality boundaries are shown in gray. 


\section{Conclusão Geral}

$\mathrm{O}$ aumento de florestas nativas em países tropicais em desenvolvimento parece promissor em vista do acelerado desmatamento nos trópicos. A Teoria da Transição Florestal associa esta reversão nas tendências de desmatamento às mudanças socioeconômicas e políticas dos países. Neste contexto, o objetivo desta tese foi identificar os fatores socioeconômicos e biofísicos relacionados ao desmatamento e à recuperação das florestas nativas do estado de São Paulo, que apresenta ganhos líquidos de florestas desde a década de 1990.

Para atingir este objetivo, o Capítulo 1 avaliou três diferentes fontes de dados de cobertura florestal disponíveis ao público para o estado de São Paulo em escala municipal (Censo Agropecuário do IBGE, mapas da ONG SOS Mata Atlântica e Instituto Florestal de São Paulo), visto que o entendimento dos fatores que levam ao desmatamento ou à regeneração depende de estimativas adequadas de florestas nativas. Este primeiro capítulo demonstrou que as três fontes de dados possuem diferenças relacionados aos métodos e às características dos municípios. Porém, estas fontes são robustas para seus respectivos objetivos principais, que estão alinhados aos métodos utilizados por cada instituto/organização (IBGE, SOS ou IF).

O Censo Agropecuário do IBGE apresenta estimativas menores de cobertura florestal em municípios com extensas áreas protegidas (Área de Proteção Permanente e Unidades de Conservação), pois limita a coleta de dados às propriedades rurais dos municípios. Mapeamentos gerados a partir de imagens com resolução de 30m, como os mapas da SOS Mata Atlântica, apresentam estimativas de cobertura florestal, quando comparadas ao IF, em paisagens muito fragmentadas onde os remanescentes estão muito isolados e são muito pequenos ou muito alongados, pois não os detectam. Porém, mapas com essa resolução podem superestimar a cobertura ao caracterizar grupos de pequenos fragmentos próximos entre si como um único grande remanescente.

Estes vieses podem refletir nos resultados de modelos construídos para predizer a quantidade de cobertura florestal. Devido às diferenças entre as estimativas, modelos para a previsão da cobertura florestal em função da porcentagem de áreas 
protegidas (e.g. Unidades de Conservação e Áreas de Proteção Permanente) e qualidade do solo para a agricultura (e.g. capacidade de retenção de água do solo) apresentaram grande variação no poder explicativo quando utilizadas diferentes fontes de cobertura florestal como variável resposta. Estes resultados podem levar a conclusões diferentes quanto a influencia das variáveis explicativas escolhidas sobre a quantidade de cobertura florestal nos municípios paulistas.

Unir dados de cobertura florestal provenientes de diferentes fontes para construir uma série temporal, por sua vez, gerou tendências controversas e tendências inexistentes para vários municípios paulistas. Logo, para escolher uma fonte adequada de dados é preciso saber se o objetivo do estudo a ser desenvolvido e os métodos utilizados para obtenção dos dados são coerentes, ou se os vieses relacionados aos métodos levariam a resultados duvidosos.

De acordo com os resultados do Capítulo 1 optou-se pelos dados do Censo Agropecuário do IBGE para desenvolver o Capítulo 2 desta tese, apesar do censo não quantificar grande parte das florestas nativas em Unidades de Conservação. Esta escolha baseou-se no fato do censo disponibilizar dados de propriedades rurais brasileiras em escala municipal desde 1960, permitindo análises em escala municipal e em longo prazo. Visto que uma porcentagem baixa da cobertura florestal nativa do estado está em Unidades de Conservação e a dinâmica do desmatamento no estado está relacionada às mudanças no uso da terra, principalmente em propriedades privadas, dados das propriedades foram considerados adequados para o estudo da transição florestal em todo o estado (e.g. 645 municípios).

Sob uma perspectiva histórica, o Capítulo 2 examinou como fatores socioeconômicos e biofísicos se relacionam às mudanças de cobertura florestal no estado de São Paulo em diferentes períodos (1960-1970, 1970-1980, 1980-1996, 1996-2006). Observamos que os ganhos de cobertura florestal foram maiores em municípios com maior porcentagem de cobertura florestal nativa, maior declividade média, maior densidade de trabalhadores permanentes nas propriedades e com intenso uso de fertilizantes. As perdas, por sua vez, foram maiores em municípios com solos mais úmidos e/ou com grande parcela do município ocupada pela agricultura e pela pecuária.

Abordando períodos consecutivos, mostramos que a transição florestal em São Paulo está relacionada à modernização da agricultura que inicialmente promoveu a 
expansão agrícola - principalmente da produção de commodities - e desmatamento em áreas mais adequadas à agricultura. No entanto, a intensificação agrícola, aliada a políticas de proteção dos ecossistemas naturais e a exigências do mercado externo por certificação ambiental, possibilitou a regeneração das florestas nativas, principalmente em áreas menos adequadas à agricultura. Ao demonstrar como os fatores relacionados ao desmatamento e à recuperação das matas paulistas variam em longo prazo, contribuímos para o refinamento futuro de políticas e projetos governamentais que buscam conciliar produção agrícola e conservação de ecossistemas naturais.

Estes resultados indicam, porém, que a transição florestal em São Paulo não é explicada por uma única via da transição florestal. O Capítulo 2 sugere que o desenvolvimento econômico relacionado à modernização agrícola (via do desenvolvimento econômico), a disseminação de ideias conservacionistas, exigindo certificação ambiental para importação de produtos paulistas (via da globalização), e a criação dos principais órgãos ambientais federais e estaduais a partir da década de 1960 (via das políticas públicas) foram responsáveis pela desaceleração do desmatamento e aumento da cobertura florestal nativa no estado de São Paulo.

Possivelmente, contudo, vias distintas de transição florestal ocorreram em algumas regiões do estado, visto que algumas culturas predominam há muitas gerações (e.g. laranja e cana-de-açúcar) em determinadas regiões, enquanto outras (e.g. café e criação extensiva de gado) declinaram nos intervalos analisados ou foram deslocadas (e.g. criação extensiva de gado) pela expansão de cultivos para exportação (e.g. cana-de-açúcar e eucalipto). Também é possível que diferentes regiões paulistas estejam em fases distintas do processo de transição florestal. Por isso, estudos futuros precisam abordar paralelamente a transição florestal em diferentes regiões para avaliar a contribuição de uma região para o desmatamento ou regeneração em outras, e também a contribuição de cada região para os ganhos líquidos de cobertura florestal de São Paulo nas últimas décadas.

Esta tese testou particularmente fatores socioeconômicos e biofísicos que influenciaram diretamente a variação da cobertura florestal em São Paulo entre 1960 e 2006, como expansão do uso das terras, mecanização, população rural e uso de fertilizantes. Porém, possivelmente, estes fatores foram influenciados por outros, agindo em escala global, como a competitividade no mercado externo, variação do dólar em relação à moeda corrente ou mesmo pela crise do petróleo na década de 
1970. Estes fatores provavelmente tiveram importante papel nas mudanças no uso da terra no estado, que foram caracterizadas pela substituição da produção familiar de alimentos para o mercado local pela produção de commodities em larga escala. Estudar como estes fatores afetaram as florestas pode ajudar a prever o quanto elas são vulneráveis a novas mudanças econômicas em longo prazo, pois é possível que a expansão de commodities sobre as matas regeneradas ocorra caso seja economicamente vantajoso para o produtor. 